\title{
SENTENCIAS Y AUTOS DEL TRIBUNAL SUPREMO Y RESOLUCIONES DE LA DIRECCION GENERAL DE LOS REGISTROS EN QUE SE CITAN, ESTUDIAN O APLICAN PRECEPTOS CONSTITUCIONALES
}

\author{
(Junio-diciembre 1980)
}

POR

ENRIQUE LINDE PANIAGUA

Universidad Nacional de Educación a Distancia

\begin{abstract}
SUMARIO
1. Repertorio de sentencias, autos y resoluciones por orden cronológico con transcripción de sus Considerandos básicos acompañados de un comentario y bibliografía sobre cada tema: A) Sentencias y autos del Tribunal Supremo;

B) Resoluciones de la Dirección General de los Registros.
\end{abstract}

1. REPERTORIO

A) Sentencias y autos del Tribunal Supremo

Núm. 2 bis. Sentencia de 25 de abril de 1980. Criminal. Ponente, M. Gómez de Liaño Cabaleda: ARTICULOS 10 Y 20 DE LA CONSTITUCION.

Libertad de expresion y difusión de pensamientos, ideas $y$ opiniones: limites Periodistas

La Constitución consagra en su artículo 20 la libertad de expresión y difusión de pensamientos, ideas y opiniones, libertad que es fundamento de la profesión periodística, pero su ejercicio tiene su límite en los derechos fundamentales determinados en el texto constitucional como establece su artículo 10.1. La vulneración del derecho al honor, límite de la libertad de expresión, comprende el desacato.

Considerando: Que la sentencia por la que se absuelve al procesado del delito de desacato - art. 244 del Código Penal-y se le condena como autor de una falta de respeto y consideración debida a la autoridad —núm. 5 del 570 del mismo Código punitivo-, es impugnada: por el Ministerio Fiscal, en único motivo, porque entiende que de su premisa fáctica se derivan los supuestos para apreciar los elementos que dan vida al delito del que fue absuelto, y por la representación del condenado, porque estima la inexistencia de infracción penal alguna, por ausencia del animus iniurandi como elemento subjetivo del injusto, y por la concurrencia de la causa de justificación de obrar «en el ejercicio de un oficio o cargo», en cuanto 
que el procesado, debido a su condición de periodista, «no hace sino cumplir la función social que tiene asignada de informar, criticar y denunciar». Estos cuatro puntos de vista sobre el enjuiciamiento - delito, falta, inexistencia de animus iniurandi y concurrencia de la causa de justificación, exonerativa de responsabilidad penal - permiten concretar la problemática casacional en la doble vertiente: a) de resolver si existe o no infracción punitiva y determinar, en caso afirmativo, su calificación jurídico-penal, y b) de analizar la posibilidad de apreciar la eximente de responsabilidad penal del núm. 11 del artículo 8 del Código Penal alegada.

Considerando: Que el delito de desacato, de acuerdo con el criterio reiterado de esta Sala —Sentencias 25-X-74, 3-VI-75, 22-III-76, 16-IX-77, 21-X-78 y 27XII-79-, requiere para su apreciación: a) en cuanto a la dinámica de la conducta del agente, la existencia de una actividad calumniosa -imputación de delito que origina la perseguibilidad de oficio-, o injuriosa -expresión proferida o acción ejecutada en deshonra, descrédito o menosprecio-, o insultante -manifestación ofensiva, provocadora e irritante-, o amenazadora - entendimiento de querer hacer un mal a otro-, dirigida a un ministro o autoridad cuando se hallaren en el ejercicio de sus funciones, o con ocasión de ellas, siendo diferente la pena según que se realice en su presencia o en escrito que le sea dirigido, o se ejecute fuera de su presencia o en escrito que no estuviere dirigido a ellos; $b$ ) en cuanto a la culpabilidad, la concurrencia de un ánimo específico y tendencial, además de la conciencia y voluntad inherente a la acción humana, de carácter injurioso o intimidante, creador de un tipo anormal por mayor dosis culpabilística que reclama todo el tratamiento del elemento subjetivo del injusto, que, sin olvidar su carácter anímico o naturaleza subjetiva, ha de ser objeto de una valoración normativa y examinado como requisito antijurídico, debido a su nota de injusto y ser inherente a la tipificación de la acción penal, y c) en cuanto a la antijuricidad, que la norma sociocultural, mediante la que se valoriza la conducta tipificada como contraria a derecho, sienta el reproche mayoritario del grupo social en cuyo entorno tienen lugar los hechos, en atención no solamente al respeto y protección que merezca el principio de autoridad -imprescindible para el mantenimiento del orden social y jurídico- y características de la personalidad del sujeto activo, sino también de cuantas circunstancias concurran para determinar la intensidad del daño producido en el bien jurídico protegido de la seguridad institucional del Estado, a través del concepto de autoridad, e incluso de la mayor o menor ausencia de gravedad que nos dará la existencia del delito o la falta o la inexistencia de la infracción penal, pues en esta graduación de la gravedad radica el criterio diferenciador de estos supuestos que plantea la calificación jurídica de la sentencia.

Considerando: Que del análisis de los hechos que la sentencia declara como probados se desprende: $10^{\circ}$, que el editorial del periódico, del que era director el procesado, fue titulado con la denominación «Prensa y democracia», y que sus primeros párrafos están encaminados a la defensa «de una prensa libre, independiente y pluralista» como demostrativa de la autenticidad de un régimen democrático, con exposición de los factores que impiden la existencia «de un libre mercado democrático de la información normalizado y homologable con el de otros países occidentales», sin poderse apreciar frases o términos susceptibles de encaje en la tipología penal; $2 .^{\circ}$, que, al tratar de los efectos de estos factores en la Administración de Justicia y actuación de los Juzgados y Tribunales, describe, como acto que llama la atención, el haber «visto a un periodista, director de una publicación, entrar a declarar al Juzgado en una camilla», cuya narración, dado el carácter equívoco que puede tener, aunque sí hiriente a la sensibilidad de ciertas personas, 
tampoco tiene encaje en la figura delictiva, y $3 .^{\circ}$, que al criticar cierta sentencia condenatoria contra determinada periodista, por fotografías pornográficas, consideradas, con criterio uniforme y reiteradísimo por la jurisprudencia, como delito ante el significado y trascendente ataque al pudor, al igual que otras legislaciones contemporáneas, emplea la frase de que «recuerda los mejores tiempos nazis o los actuales de un Amín Dada» y la califica de inquisitorial, frases y calificativo que simbolizan, en la Administración de Justicia o función judicial, desde el estado cultural de la sociedad actual, la máxima violación de los derechos humanos y garantías procesales. Esta simbolización permite apreciar el carácter del ánimo injurioso como grave para el Tribunal creador de la sentencia criticada y considerar las frases y calificación como constitutivas del delito de desacato, patrocinado por el Ministerio Fiscal, en cuanto que encierran grave descrédito, y con ello estimar su único motivo y desestimat el primero de los interpuestos por el procesado, sin que la protesta de dejar a salvo el honor de los Tribunales y la autocalificación de la frase como desafortunada, fuera del escrito y posteriormente, puedan degradar el delito a falta, máxime si se tiene en cuenta la naturaleza ilativa de la injuria, que, al necesitar para su realización una mayor meditación, dota al intelecto de cierto raciocinio, que reclama una valoración más intensa en la gravedad e impide la no apreciación del ánimo de injuriar, como pretende el defensor recurrente y recoge la sentencia.

Considerando: Que la eximente de responsabilidad, como causa de justificación en el obrar, en virtud de realizar los hechos en cumplimiento de un deber o en el ejercicio legítimo de un derecho, oficio o cargo — núm. 11 del artículo 8 del Código Penal-, distingue tres actividades exonetativas: actuar ante exigencias del deber de naturaleza legal, amparo o tutela del derecho y protección del ejercicio de la profesión, dentro de los límites que determinan su desarrollo legal, por lo que todo acto que se realice en el ejercicio del deber, derecho, oficio o cargo no puede estar comprendido en esta causa de exención de responsabilidad, en cuanto que significaría la violación del requisito de legalidad que la misma exige y la impunidad de toda clase de actividad ejecutada en el ejercicio profesional, del derecho y del deber, lo que es inadmisible ante la posibilidad de lesionar los bienes jurídicamente protegidos por el ordenamiento penal, debiéndose declarar, por afectar al caso que se enjuicia en el recurso, que si la Constitución -ley suprema que reclama la observancia total de sus preceptos- establece, en su artículo 20, la libertad de expresión y difusión de los pensamientos, ideas y opiniones - que es fundamento de la tutela jurídica de la profesión de periodista y de donde nace la facultad de criticar, que. eliminaria el delito de desacato-, también dispone, en ese mismo artículo, sus limites, basados en el respeto a los derechos que se determinan como fundamentales en el texto constitucional; en los preceptos de las leyes que la desarrollan, y especialmente en el derecho al bonor - bien que entra en juego en el desacato-, a la intimidad y propia imagen de la persona y a la protección de la juventud y de la infancia, todo ello como garantía de la dignidad y derechos de los demás, como fundamento del orden político y la paz social, que proclama, en primer término, la propia Constitución en su artículo 10. Por estos asertos acabados de exponer, esta Sala se ve obligada a declarar que, aun reconociendo el derecho de expresión $y$ difusión del pensamiento como derecho natural y fundamental de la persona, acatado con el criterio liberal del sistema político-social que recoge la vigente Constitución, las actividades y conductas que se bagan con manifiesta infracción legal no permiten ser justificadas a través del ejercicio profesional, principalmente en beneficio del propio sistema político-social, que exige, para su vigencia, el máximo respeto de sus instituciones, entre las que se encuentra el Poder Judicial, pilar fundamental y básico en el funcionamiento del Estado, que, por otra parte, si se 
tiene en cuenta su ausencia de beligerante en la función que se le tiene encomendada, merece el máximo respeto.

Considerando: Que la operatividad subsuntiva de los supuestos que constituyen la premisa fáctica de la sentencia en los postulados de la anterior doctrina sobre el cumplimiento del oficio o cargo, como causa eliminatoria de la responsabilidad penal que aboga el recurrente como autor de los hechos, pone de relieve, de forma clara y terminante, que la digna función del periodista, que debe tener como fin primordial la enseñanza y divulgación de la verdad, ha de realizarse sin extralimitaciones que lesionen los derechos y bienes protegidos por el ordenamiento penal, entre los que se encuentra de modo particular el honor de cuantos encarnan los órganos de instituciones básicas para el funcionamiento del Estado, por lo que estas extralimitaciones no pueden ser amparadas, de modo alguno, en la justificación del cumplimiento de la profesión, como tiene declarado esta Sala en Sentencias de 25 de octubre de 1974 y 27 de diciembre de 1979, en las que, a pesar de que el animus iniurandi se encontraba mitigado por el ius defendendi y el ius criticandi, se pone de relieve la punibilidad de lo que se expone de manera innecesaria y con ánimo de descrédito al principio de autoridad. $\mathrm{Y}$ como de los hechos declarados como probados se desprende que el periodista procesado, en su función crítica, con olvido del criterio positivo o negativo que la misma ha de tener para el perfeccionamiento de la convivencia humana, manifiesta las expresiones que dan vida al delito de desacato, hay que declarar la extralimitación, por él mismo reconocida como expresión polémica poco afortunada, como no susceptible de ser amparada en la eximente del núm. 11 del artículo 8 del Código Penal y con ello la desestimación del segundo y último motivo del escrito formulado, para la interposición del recurso, por parte del procesado.

\section{Comentario}

La Sentencia de 25 de abril de 1980 casa y anula la Sentencia de 9 de mayo de 1979 (que absolvía al procesado del delito de desacato y lo condenaba como autor de una falta de respeto y consideración a la autoridad) recurrida por el Ministerio Fiscal y por el director del diario El País y en segunda sentencia condena al director del diario $E l$ País como autor del delito de desacato.

Esta sentencia, que tuvo gran eco en la prensa diaria, alcanza como conclusión que los derechos fundamentales y libertades públicas tienen su límite en los derechos de los demás, y especialmente, conforme a lo dispuesto en el apartado $4 .^{\circ}$ del artículo 20 , en el derecho al honor. A juicio del Tribunal, se vulnera por el artículo publicado en el diario El País el honor de los Tribunales, vulneración que es posible subsumir en el delito de desacato.

Núm. 6. Sentencia de 25 de junio de 1980. Contencioso-Administrativo. Sala III. Ponente, J. L. Ruiz Sánchez: ARTICULO 9.3 DE LA CONSTITUCION.

\section{Irretroactividad: Principio de irretroactividad}

La Constitución garantiza en su artículo 9.3 la irretroactividad de las disposiciones sancionadoras no favorables o restrictivas de derechos individuales.

Considerando: Que se impugna la resolución dictada por la Dirección General de Comercio Interior, de fecha 2 de octubre de 1973 -Dirección de Disciplina de Mercado-, que impuso la multa de 500.000 pesetas a la empresa recurrente, Frigoríficos Berbes, S. A., por la venta de filetes de merluza congelada a precios ilícitos, ya que no fue obtenida autorización previa de la subcomisión de precios, 
a través de la Comisión Provincial Delegada en las diversas ocasiones en que ha precedido el aumento del valor de la mercancía que constituye actividad de dicha empresa, resolución que fue extemporáneamente confirmada por la dictada por el ministro de Comercio, que, haciendo uso del artículo 53 de la LPA, convalidó la resolución recurrida en alzada; impugnación que centra la parte actora en la ilegalidad del quantum impuesto como sanción en el acuerdo recurrido y el posterior que lo confirmó y convalidó, ya que, levantada acta por inspectores de la Delegación Provincial de Abastecimientos y Transportes de Burgos, en 10 de marzo de 1972, complementadas por otras llevadas a efecto por agente-inspector del Indime, el 17 de mayo de 1972 y 16 de junio de igual año, dio lugar a que se estimasen como infringidos los artículos 8. y 9. de la Orden de la Presidencia del Gobierno de 9 de julio de 1970 , en relación con los párrafos $10^{\circ}$ y $2 .^{\circ}$ del artículo $3 .^{\circ}$ del Decreto 3052/1966, de 17 de noviembre, que atribuía facultad sancionadora al organismo resolutorio hasta 60.000 pesetas, quantum que fue objeto de modificación por Decreto $2693 / 1972$, de 15 de septiembre, elevando la competencia sancionadora atribuida al director general de Comercio Interior hasta 500.000 pesetas, decreto que fue el que se ha aplicado, con un criterio de retroactividad inadmisible para sancionar hechos acaecidos antes de su promulgación, aun cuando se haya tratado de sanar la ilegalidad de la sanción impuesta.

Considerando: Que es inconcuso que la comisión de los hechos susceptibles de sanción administrativa, como derivación de haberse conculcado un específico ordenamiento, es cuestión indubitada, incluso la conducta jurídico-procesal de la parte implica un paladino reconocimiento de la imputación, pero asimismo es preciso reconocer que las normas conceptuadas como infringidas, tanto en su tipificación como en su efectividad sancionadora, tienen que ser adecuadas, en su aplicación en el tiempo, con el ordenamiento jurídico vigente en el momento en que la comisión se efectuó, porque, en aplicación de las normas de Derecho administrativo, rige la regla procedente del Derecho común de que las normas comienzan su vigencia con la publicación, con la previa vocatio legis, a falta de especificación expresa, de acuerdo con el artículo 2.0-1 del Código Civil, en relación con lo prevenido en el 132 de la LPA, sin que se admita la retroactividad, pues «las Leyes» no tendrán tal efecto - art. 2..$^{\circ}$ del Código Civil- si no dispusieren lo contrario, constituyendo excepción la retroacción, y este efecto viene consagrado o es reflejo, además de lo expuesto por el artículo 45 de la LPA, sin que la posibilidad convalidante pueda sanar la aplicación retroactiva de una norma respecto de supuestos acaecidos bajo el imperio de otra anterior, pues a ellos se oponen el principio de irretroactividad, que tienden a proteger a los particulares frente a la Administración, que, actuando hacia el pasado, agrave la situación de los ciudadanos, situación que ha de ser contemplada con un mayor rigor cuando se trata de materias sancionadoras, por las repercusiones que sobre el patrimonio del afectado se producen, salvo expresa retroactividad establecida, consagrándose tal consecuencia en el artículo 9.3 de la vigente Constitución, que "garantiza... la irretroactividad de las disposiciones sancionadoras no favorables o restrictivas de derechos individuales», sobre todo cuando, con la retroactividad in peius, se agrava la situación del sancionado, asignando a una disposición, no Ley, un efecto ex tunc inadmisible; pero, independientemente de lo consignado, es preciso destacar que nos encontramos en presencia de una norma, con categoría de decreto -Decreto 2693/1972, de 15 de septiembre-, que carece in natura de la posibilidad retroactiva, pues esta posibilidad es, en esencia, patrimonio de las disposiciones con rango de Ley.

Considerando: Que, como derivación de lo expuesto, la actuación del órgano administrativo que resolvió en alzada pretendiendo sanar la resolución originaria, 
que, aplicando norma posterior en el tiempo a la fecha de comisión de los hechos imputados al amparo del artículo 53 de la LPA, carece de todo rigor lógico jurídico, puesto que el acto resolutorio que pretende ser objeto de sanción, al aplicar una norma posterior con un criterio de retroactividad inadmisible, incide en la pretensión de sanar no un acto aceptado del vicio de anulabilidad, sino un acto contra legem, con un objetivo exclusivo de sancionar con un rigor excesivo no previsto ni querido por la norma, estimada como infringida en el tempus en que la transgresión se cometió, procediendo en consecuencia declarar la nulidad de las resoluciones recurridas, por no estar aceptadas en Derecho, debiéndose retrotraer el procedimiento al momento en que las resoluciones se anulan al objeto de que se dicte la que proceda.

Considerando: Que no procede hacer expresa condena en cuanto a las costas causadas en este recurso a parte determinada.

\section{Comentario}

La Sentencia de 25 de junio de 1980 cita el artículo 9.3 de la Constitución española, en que se consagra al más alto rango el principio de irretroactividad de las disposiciones sancionadoras no favorables o restrictivas de derechos individuales, principio que regía en nuestro ordenamiento antes de la entrada en vigor de la Constitución de 1978, y desde luego en relación a las disposiciones reglamentarias como es el Decreto 2693/1972, de 15 de septiembre, objeto de la sentencia que comentamos. No por ello deja de ser importante el principio consagrado en el artículo 9.3 de la Constitución, que ahora prohíbe la retroactividad sin excepciones $\mathrm{y}$, por consiguiente, alcanza a las leyes cuando de disposiciones sancionadoras se trata.

Sobre la irretroactividad de las disposiciones reglamentarias véase E. García de Enterría y T. R. Fernández, Curso de Derecho administrativo, I, 1975, págs. 70 a 75 , y Curso de Derecho administrativo, I, Madrid, 1980, págs. 74 a 80.

Núm. 7. Sentencia de 25 de junio de 1980. Contencioso-Administrativo. Sala IV. Ponente, E. Díaz Eimil: ARTICULOS 10, 19 Y 35 DE LA CONSTITU. CION.

Derechos y libertades: fundamento del orden político

$y$ de la paz social

Derecbo a elegir libremente residencia

Derecho a entrar y salir libremente de España

Derecho al trabajo

Los derechos a entrar y salir libremente de España están reservados, según expresa el artículo 19 de la Constitución, a los españoles.

Los derechos de los extranjeros a elegir libremente residencia y al trabajo están supeditados al derecho a entrar en territorio español.

«PRIMER CONSIDERANDo: Que en el recurso se examina la legalidad de la resolución del gobernador civil de Las Palmas de dos de octubre de mil novecientos setenta y nueve, en cuanto acto administrativo final desestimatorio de la reposición deducida frente a la de quince de mayo anterior de la propia autoridad, por la que se decidió archivar sin más el expediente instado por don K. D. P. en solicitud de permiso de trabajo y autorización de residencia, disponiéndose además que, por el Cuerpo General de Policía, se dé inmediato cumplimiento a la medida de expulsión del territorio nacional que pesaba sobre el recurrente, caso de ha- 
ber sido infringida la prohibición de entrada.-SEgundo considerando: Que para dilucidar sobre el supuesto litigioso se hace conveniente exponer una relación suficientemente pormenorizada de los antecedentes de las resoluciones impugnadas, a saber: Primero, con fecha siete de febrero de mil novecientos setenta y ocho se decretó, por el Excmo. Sr. Director General de Seguridad, orden de expulsión del territorio nacional, con prohibición de entrada en España por espacio de dos años, aunque sea portador de documentación regular, al súbdito hindú, hoy recurrente, D. K. P. Al nótificar esta resolución al interesado, el veintiséis de mayo de mil novecientos setenta y acho, queda advertido y se da por enterado de que el quebrantamiento de esta medida setá causa de su puesta a disposición de los Tribunales de Justicia. El afectado por la orden de expulsión salió, efectivamente, de España por el aeropuerto de Málaga, el día diez de agosto de mil novecientos setenta y ocho. No obstante lo anterior, el aludido súbdito hindú entra en territorio español, por el aeropuerto de Barajas, el nueve de noviembre de mil novecientos setenta y ocho. Segundo, el diecinueve de febrero de mil novecientos setenta y nueve solicita ante el Gobierno Civil de Las Palmas permiso de trabajo y autorización de residencia, dictándose resolución por el gobernador civil, el quince de mayo de mil novecientos setenta y nueve, en la que se dispone el archivo sin más de las actuaciones, por razones de orden público, y ordenando que, por el Cuerpo General de Policía, se dé inmediato cumplimiento a la medida de expulsión, caso de haber sido infringida la prohibición de entrada. Mediante oficio de cuatro de junio de mil novecientos setenta y nueve, la Dirección General de Seguridad participa al gobernador civil de Las Palmas haberse acordado dejar sin efecto las medidas de expulsión y prohibición de entrada por dos años que pesaban sobre el recurrente. El once de junio de mil novecientos setenta y nueve se interpuso por éste recurso de reposición frente a la citada resolución del gobernador de la Provincia de quince de mayo anterior. Mediante nuevo oficio de diecisiete de julio de mil novecientos setenta y nueve, la Dirección General de Seguridad participa haber reconsiderado el caso y dispone que sea inmediatamente expulsado el súbdito hindú hasta tanto cumpla la prohibición de entrada, que fue quebrantada (comunicación que no consta notificada al recurrente). En escrito de doce de septiembre de mil novecientos setenta y nueve, el interesado solicita del gobernador civil deje sin efecto la orden de expulsión hasta la resolución del recurso de reposición, por causársele graves perjuicios, y mediante escrito de veintisiete siguiente aporta certificación de buena conducta de la Guardia Civil y Policía de Maspalomas, aduciendo "ya que uno de los motivos de la resolución de ese Gobierno Civil, reiterando la expulsión, estriba en los malos antecedentes del que suscribe". Con fecha dos de octubre de mil novecientos setenta y nueve, el Gobierno Civil resuelve desestimar la reposición pretendida.-TERCER CONSIDERANDO: Que, aunque no se citan en la demanda ni en ninguno de los escritos del recurrente, los derechos fundamentales de la persona a libertades públicas de los que se crea asistido, que hayan podido ser quebrantados por el acto administrativo que se impugna, parece deducirse del contexto de sus pretensiones que se reclama, al amparo de los derechos de "libre entrada y salida de España", "elección libre de residencia" $y$ "derecho al trabajo", proclamados por los artículos diecinueve y treinta y cinco de la Constitución de veintisiete de diciembre de mil novecientos setenta y ocbo, respecto de los cuales conviene ya desde aquí precisar que el primero de ellos, esto es, el derecho de entrar libremente en España, es inexcusable presupuesto de los otros dos, puesto que si no está asegurada la libertad de entrar en un territorio no se puede pretender el derecho a elegir el lugar de residencia y de trabajo en él, de suerte que el problema litigioso queda así circunscrito al examen de la medida de expulsión del territorio nacional, concretada en la resolución recurrida y condicionada a la comprobación de que, efectivamente, se bubiera incumplido la probibición de entrada que pesaba sobre el recurrente.-CuARTo CONSIDERANDo: Que lo primero que se 
advierte en esta medida de expulsión del territorio nacional, cuya anulación se postula en este concreto recurso juntamente con la pretensión individualizada de que se declare que el recurrente está legitimado para "estar" en España, es que se trata de un acto ejecutivo o de vigilancia y cumplimiento respecto de la resolución adoptada en siete de febrero de mil novecientos setenta $y$ ocho por el director general de Seguridad, que fue la que decretó la expulsión del recurrente, con la secuela de prohibición de entrada por dos años en territorio español, y como, obviamente, esta resolución no es la que aquí se discute, cae por su base la pretensión de enjuiciamiento del acto del gobernador civil dirigida meramente a dotarla de efectividad; pero, con independencia de esto, vale decir, aun aceptando que el acto ejecutivo estuviera investido de la necesaria autonomía para ser revisado por la jurisdicción, ha de repararse igualmente en que lo resuelto por el gobernador de Las Palmas no es una expulsión en sentido propio, frente a la que pudiera invocarse el artículo trece del Pacto Internacional de Derechos Civiles y Politicos (Nueva York, diecinueve de diciembre de mil novecientos sesenta y seis), que entró en vigor en España el veintisiete de julio de mil novecientos setenta y siete, conforme al cual "el extranjero que se halle legalmente en el territorio de un Estado parte en el presente Pacto sólo podrá ser expulsado de él en cumplimiento de una decisión aceptada conforme a la Ley...", sino que dicha resolución se limita a decretar la salida de España de un extranjero, condicionada a la comprobación de que, efectivamente, baya quebrantado la probibición de entrada, lo que supone el recto lucimiento de una situación de becho que no entraña "expulsión", por la sencilla razón de que el afectado por la medida "no se balla legalmente en el territorio nacional". QUINTO CONSIDERANDO: Que, por lo demás, aunque el derecho a elegir la residencia en el territorio de cualquier Estado viene proclamado como ideal común de todos los pueblos por el artículo 13.1 de la Declaración Universal de Derechos Humanos (Paris, diez de diciembre de mil novecientos cuarenta $y$ ocho), normativa de interpretación mandada observar por el artículo 10.1 de nuestra Constitución de veintisiete de diciembre de mil novecientos setenta y ocbo, es lo cierto que tal idea no ba conseguido hacerse realidad, y que el artículo diecinueve del citado texto constitucional reserva este derecho a los nacionales, al disponer que "asimismo tienen derecho (los españoles) a entrar y salir libremente de España en los términos que la Ley establezca".-SEXTo consrderando: Que en lo concerniente a la reclamación de los derechos de residencia y de trabajo que constituyen la petición impulsora del expediente que fue archivado "sin más" por la resolución objeto de este recurso, cabe añadir la reflexión fundamental, o si se quiere elemental, de que el Estatuto de extranjería, en cuanto a la posibilidad de que un extranjero pretenda obtener los permisos y licencias determinados por la legislación nacional (Decreto mil diecisiete, de mil novecientos setenta y ocho, de dos de junio, y Decreto mil setecientos veintiuno, de la misma fecha, entre otros), supedita la exigencia a la previa comisión de dicho extranjero en España, momento en que cae automáticamente bajo la soberanía territorial del Estado; de aquí que, encontrándose el recurrente en situación legal de expulsado, con probibición de entrada durante dos años, se manifieste que carece de la precisa babilitación para invocar los derechos que postula en el recurso.- SÉPTIMO CONSIDERANDO: Que cuando se dictó la primera resolución del Gobierno Civil, el quince de mayo de mil novecientos setenta y nueve, decretando el archivo sin más del expediente, no había recibido aún el oficio del comisario general de Seguridad (cuatro de julio siguiente) participando haberse dejado sin efecto la orden de expulsión, y cuando se resuelve por la propia autoridad provincial el recurso de reposición (dos de octubre de mil novecientos setenta y nueve), figuraba ya en el expediente el oficio de la misma Comisaría General de Seguridad (diecisiete de julio anterior), participando que, reconsiderado el caso, la Dirección General de Seguridad ha dispuesto su inmediata expulsión hasta tanto cumpla la 
prohibición de entrada que fue quebrantada por el recurrente, y como quiera que esta comunicación sólo hay que tomarla como presupuesto de becho de la resolución del Gobierno, se trata de una decisión de la Dirección General de Seguridad conectada con la resolución de tal organismo directivo de siete de febrero de mil novecientos setenta y ocho, por el que se decretó la inicial expulsión y prohibición de entrada en España del recurrente, y, por tanto, materia ajena a la que es objeto de nuestro enjuiciamiento.-OCTAvo CONSIDERANDo: Que, con arreglo a lo ordenado en el artículo 10.3 de la Ley de Protección Jurisdiccional de los Derechos Fundamentales de la persona, sesenta y dos de mil novecientos setenta y ocho, de veintiséis de diciembre, al ser totalmente rechazadas las pretensiones del recurrente deben declararse a su cargo el pago de las costas procesales.»

Resultando: Que contra la anterior sentencia interpuso apelación don K. D. P., alegando como motivos los siguientes: De forma, que descansaba la resolución combatida en vía contenciosa en motivos de orden público que no babian sido concretados ni recogidos en la sentencia apelada de un lado, y de otro, que pudiendo ser uno de tales motivos la infracción de entrada en España por el recurrente en plazo inferior a dos años, conforme a resolución de la Dirección General de Seguridad, de fecha diecisiete de julio de mil novecientos setenta y nueve, que la determinaba, dicba resolución, como se recogía en la propia sentencia, no babia sido notificada al recurrente, lo que producía manifiesta indefensión; y de fondo: porque la sentencia apelada citaba normas legales de las que bacía aplicación indebida la Sala sentenciadora; recurso de apelación que fue admitido en ambos efectos, con emplazamiento de las partes y remisión de los autos a este Tribunal, ante el que se personó, en tiempo y forma, el procurador don E. R. C., en representación del apelante don K. D. P., a quien se tuvo por parte, acordándose pasar las presentes actuaciones al Excmo. Sr. Magistrado Ponente designado en las mismas, para la resolución procedente.

Visto, siendo Ponente el Magistrado Excmo. Sr. D. Eugenio Díaz Eimil.

Vistos el Decreto de 2 de junio de 1978; los artículos 27 del Código Civil; 10, 19 y 39 de la Constitución española; la Ley de Protección Jurisdiccional de los Derechos Fundamentales de la Persona de 28 de diciembre de 1978 y demás normas y jurisprudencia de aplicación,

Se aceptan los considerandos de la sentencia apelada; y

ConsIderando: Que siendo incuestionable e indiscutido que el Acuerdo del director general de Seguridad de 7 de febrero de 1978 ordenó la expulsión del territorio nacional del recurrente, súbdito hindú, con probibición de entrada por espacio de dos años, y que este acuerdo fue aceptado y cumplido en su primer pronunciamiento por el interesado, al abandonar el territorio nacional por el aeropuerto de Málaga, el día 18 de agosto del mismo año, y quebrantado en el segundo al volver a entrar en España por el aeropuerto de Barajas, el día 9 de noviembre siguiente, es igualmente incuestionable que el acuerdo recurrido del gobernador civil de Las Palmas, de 2 de octubre de 1979, por el cual se ordenó el archivo de su solicitud de permiso de trabajo y autorización de residencia y su expulsión por baber infringido aquella probibición de entrada que le babía impuesto el acuerdo directivo anteriormente citado, constituye consecuencia obligada e ineludible de quebrantamiento, que restaura la eficacia y debido cumplimiento de ese acuerdo firme y consentido, y por ello la confirmación que de la resolución recurrida bace la sentencia apelada se manifiesta como de intacbable corrección jurídica, sólidamente fundada en el acertado y completo estudio que de la cuestión litigiosa se hace en sus considerandos, a cuya aceptación por esta Sala no pueden eficazmente oponerse las alegaciones consistentes en que no se concretan los motivos de orden 
público que justifican la resolución confirmada, que el acuerdo de la Dirección General de Seguridad, de 17 de julio de 1979 , no ha sido notificada, ocasionándose con ello indefensión, y que se hace indebida aplicación de las normas legales, puesto que tales alegaciones están suficientemente rebatidas en dicha sentencia de tan evidente manera, que dispensan de todo otro razonamiento que indefectiblemente resultaría reiterativo.

Considerando: Que la desestimación total del recurso de apelación comporta la imposición de costas al apelante, a tenor de lo dispuesto en el número 3 del artículo 10 de la Ley de 28 de diciembre de 1978.

\section{Comentario}

Según se expresa en la sentencia, para los extranjeros el derecho a la libre elección de residencia y al trabajo están condicionados al disfrute del derecho a entrar y salir libremente de España.

La sentencia después de recordar que conforme al artículo 10.2 (dice en el texto 10.1) de la Constitución la interpretación de los derechos fundamentales y libertades públicas debe hacerse conforme a los tratados internacionales suscritos en la materia por España (concretamente cita el artículo 13.1 de la Declaración Universal de Derechos Humanos hecha en París el 10 de diciembre de 1948), alcanza en el quinto considerando una conclusión que no es muy afortunada por cuanto del juego entre los artículos 10.2 y 19 del texto constitucional no se desprende ineludiblemente que el derecho a entrar y salir de España esté reservado exclusivamente a los españoles. A nuestro juicio, la ley de extranjeros podrá establecer límites al ejercicio de dicho derecho que en principio tienen los extranjeros conforme a lo dispuesto por el artículo 13 del propio texto constitucional que transfiere a la Ley la regulación de los derechos fundamentales de la extranjería en España.

De este modo, y en tanto no se dicte la referida ley de extranjería, está permitida una interpretación amplia del artículo 19 de la Constitución que incluye a los extranjeros. Conviene de otra parte señalar que las distintas denominaciones «ciudadano», «todos», "toda persona», «los españoles» debe hacerse con criterio amplio, porque los propósitos del constituyente no entiendo que puedan conectarse al objetivo de excluir. En el caso que nos ocupa parece lógico que los derechos del artículo 19 de la Constitución se refieran a los españoles, porque son derechos conectados al territorio español, pero no deben entenderse un propósito de excluir del disfrute de los derechos a los extranjeros.

Véase, especialmente, el comentario de J. L. Piñar Mañas, El derecbo a la libertad de residencia y circulación de los extranjeros en el territorio nacional, en RAP, núm. 93, septiembre-diciembre 1980.

Núm. 8. Sentencia de 27 de junio de 1980. Contencioso-Administrativo. Sala III. Ponente, J. L. Martín Herrero: ARTICULOS 3, 24.2 Y 53 DE LA CONSTITUCION.

Principio de presunción de inocencia: vincula a todos los poderes públicos

Los documentos en lengua diferente a las españolas reconocidas en el artículo 3 de la Constitución no pueden surtir efectos en España sino después de la correspondiente adveración, autenticación y pertinente traducción.

La Constitución, en su artículo 24.2, consagra el principio de presunción de inocencia en tanto no se pruebe lo contrario.

Considerando: Que el art. 24.2, inciso último, de la Constitución de 27 de diciembre de 1978 declara el derecho de todos los españoles a la presunción de 
inocencia, declaración que, según el art. 53, vincula a todos los poderes públicos, por lo que bay que partir de esa presunción «iuris tamtum» de inocencia, que, como todas las de su clase, puede ser destruida mediante la prueba en contrario, que en este caso concreto será la de la culpabilidad del agente, lo que significa que la falta de prueba de esa culpabilidad equivale a la prueba de la inocencia, en virtud de la presunción constitucional; y no pueden invertirse los términos y entender que es el inculpado a quien corresponde probar que es inocente, sino que esto debe presumirse siempre y sólo entender destruida la presunción cuando los órganos encargados de efectuar la correspondiente acusación o la persecución de las infracciones prueben su culpabilidad en forma cierta e inequívoca, puesto que en caso de duda ésta deberá actuar en beneficio del imputado; por ello, por muy hábiles o sofisticados que sean los medios o los procedimientos para realizar las infracciones de contrabando, en virtud de la presunción anteriormente establecida es preciso llevar al ánimo del Tribunal - cualquiera que sea su naturaleza- la convicción de la realización del hecho criminal y la indicación del culpable, por lo que la prueba que se practique para destruir la presunción de inocencia ha de ir dirigida, primeramente, a convencer al juzgador de la existencia o realización de los hechos delictivos que puedan ser relevantes $y$, posteriormente, a acreditar que estos hechos fueron realizados por la persona del imputado, para lo cual pueden emplearse todos los medios de prueba que legalmente se admitan y que puedan servir para producir en el juzgador ese convencimiento, pero perteneciendo a éste, como facultad indeclinable, la libre valoración de toda la que se practique.

Considerando: Que en el presente caso la existencia o realización de los hechos delictivos está íntimamente relacionada con la valoración de la prueba practicada, puesto que para acreditar el hecho imputado -el embarque de un cargamento de cigarrillos en el puerto franco de Bremen, a bordo del buque español «Ciudad de Alicante»- se han presentado unos medios de prueba consistentes en unos documentos remitidos por las autoridades aduaneras alemanas a las españolas, en mera fotocopia compulsada con sus originales, pero no autenticados tales documentos ni por las correspondientes firmas o sellos de las autoridades aduaneras alemanas, ni, sobre todo, acompañadas de su correspondiente traducción al castellano, y sin que tampoco esta traducción haya sido realizada por las autoridades españolas, por lo que, siendo esta lengua la única oficial del Estado español, según el art. 3 de la Constitución, carecen de relevancia alguna los documentos remitidos por las autoridades alemanas, puesto que una cosa es que exista un Convenio de Asistencia Mutua entre las autoridades aduaneras de España y de la República Federal de Alemania y otra cosa muy distinta que todos los documentos enviados por las respectivas autoridades, en su lengua de origen, deban surtir plenos efectos ante las autoridades españolas sin la correspondiente adveración y autenticación, y la pertinente traducción, ya que aunque la Administración o algunos de sus órganos los admitieron en tal forma, ni pueden ni deben surtir sus efectos ante los Tribunales de Justicia, cuyo conocimiento particular de idiomas distintos del castellano ni es exigido por las Leyes procesales u orgánicas ni, en caso de conocerlos, puede servir para hacer uso de ellos en las actuaciones procesales, porque precisamente ello sería extraprocesal y, en algunos casos, productos de indefensión de los inculpados; pero es que, además, el propio Convenio de Asistencia, de 27 de noviembre de 1969, ratificado por Instrumento de 18 de mayo de 1970 y publicado en el Boletín Oficial de 20 de agosto de 1971 exige en su art. 6 que los documentos que se remiten sean «informes, actas o copias certificadas de documentos» y se refieran a «operaciones comprobadas o proyectadas» —art. 6-, estableciendo a su vez el art. 8 que «la fuerza probatoria de tales documentos, así como el uso que de ellos se haga en justicia, dependerá del derecho nacional», añadiendo a continuación que «cuando deban auten- 
ticarse determinados escritos lo serán por los funcionarios de las administraciones aduaneras a este fin designadas", trámites todos ellos incumplidos en el presente caso, lo que obliga a rechazar los documentos remitidos, primero y principalmente por falta de traducción, después por falta de autenticación (ya que no equivale a ella la mera compulsa de la fotocopia con el original) y por último por la serie de irregularidades puestas de manifiesto en la Sentencia apelada, tales como el error en el nombre del capitán del buque en uno de los viajes, el error en la consignación del puerto español, las rectificaciones, errores y correcciones que en otros se contienen, que afectan incluso al total de la mercancía presuntamente embarcada e incluso la falta de identificación de la firma de quienes la estamparon en varios de ellos, uno de los cuales incluso pudiera ser la de un súbdito alemán, como alegan los apelados, por lo que dichos documentos no pueden ser admitidos como medios de prueba dentro de un proceso seguido ante órganos jurisdiccionales.

CoNSIDERANDO: Que como precisamente mediante tales documentos quiere darse como probado el hecho del embarque de la mercancía en el buque español «Ciudad de Alicante» en el puerto franco de Bremen (cuya mercancía no fue aprehendida al llegar el buque a puerto español), este hecho no puede darse como probado, al no haberse llevado al convencimiento del juzgador la realización de los hechos relevantes, no, por tanto, el hecha básico del cual se puedan derivar los posteriores constitutivos de la infracción sancionada, pues es evidente que al no haberse justificado el embarque de la mercancía mal puede deducirse - -sin faltar a las reglas del criterio humano - el desembarco de esa misma mercancía en territorio español, por lo que no solamente no puede hablarse de prueba de presunciones -al faltar la prueba del hecho inicial cierto al que se conectan lógica y congruentemente los otros hechos posteriores-, sino que ni siquiera puede hablarse de meros indicios, puesto que ni se justificó el embarque de la mercancía en el puerto de Bremen ni esta mercancía se aprehendió en territorio español, y además han quedado acreditadas por declaración del funcionario del Consulado español en Bremen, señor B., las irregularidades que en aquellas fechas se descubrieron en aquel puerto, y en el que estaba implicado algún funcionario de la aduana alemana, lo que ha sido ratificado por las noticias de la prensa - convenientemente traducidas-, de las que resultan las condenas a tales funcionarios por los Tribunales alemanes, lo que obliga a concluir cuando menos, concediendo a los inculpados el beneficio de la duda, ya que, como apuntan los defensores, ni siquiera se ha acreditado la diferencia del precio de los cigarrillos entre España y Alemania para justificar así el posible beneficio que la introducción clandestina en España podría proporcionar a sus autores, estando por lo tanto, dentro de lo posible, la simulación de un embarque de dicha mercancía a bordo del buque y su posterior desembarco en el propio puerto franco alemán para su distribución en la República Federal, hipótesis que podrá o no ser cierta, pero que no puede ser olvidada y de la que no se puede prescindit, para hacer recaer sobre súbditos españoles el peso de una Ley, cuando son varios los posibles destinos de la mercancía, incluso en la hipótesis - que no se admite como cierta- de que ésta hubiera sido cargada a bordo del buque español.

Considerando: Que el abogado del Estado combate la Sentencia alegando que uno de los capitanes del buque admitió la «posibilidad» de que la mercancía pudiera haber sido cargada a bordo sin su conocimiento, posibilidad que no equivale a reconocimiento del hecho de la carga ni a la certeza de que este hecho se produjo, sino que simplemente indica que este hecho pudo suceder, pero que también pudo no suceder, es decir, que se trata de algo contingente, hacedero, pero no equivalente en ningún caso a algo cierto, seguro e inequívoco, por lo que queda en duda este hecho esencial del que no pueden derivarse otros posteriores ni, por consiguiente, 
darse como probada la entrada de la mercancía en un puerto español, puesto que por la misma razón, y siguiendo la argumentación de «posibilidades», la mercancía pudo desembarcarse en el mismo puerto alemán, o pudo transbordarse a otras embarcaciones fuera de las aguas jurisdiccionales españolas, o pudo ser arrojada al mar, puesto que el número de posibilidades es infinito, y si las admitimos respecto del hecho inicial, las mismas razones existen para admitirlas respecto de los hechos intermedios y respecto del hecho final, que no puede ser el más perjudicial y el que precisamente determine la condena de los inculpados, a quienes hay que presumir inocentes mientras no se haya probado su culpabilidad por algo más que meras posibilidades.

Considerando: Que tampoco puede admitirse, como pretende el abogado del Estado, que sea indubitada la firma que aparece en uno de los documentos, mediante lo que se quiere acreditar el embarque de la mercancía, puesto que lo único que hizo el Tribunal de Contrabando fue comprobar la fotocopia de la firma estampada en uno de los documentos remitidos por las autoridades alemanas con la fotocopia del Documento Nacional de Identidad de uno de los tripulantes del buque, pero sin practicar la pertinente prueba pericial caligráfica sobre firmas indubitadas, por lo que hay que rechazar la «convicción» a que ha llegado el Tribunal de Contrabando respecto de la identidad de ambas firmas, a cuya «convicción» no puede llegar, desde luego, este Tribunal de Justicia; lo mismo puede decirse respecto de la admisión del embarque de los cigarrillos deducida de la declaración prestada por el maquinista señor F. O., por las convincentes razones expuestas en la Sentencia apelada, es decir, por las manifestaciones hechas posteriormente por el propio señor $F$. en comparecencia realizada ante un notario - téngase en cuenta su cualidad de maquinista y las frecuentes ausencias que ello origina-, y sobre todo por las específicas funciones que los arts. 612, 627, 632 y 649 del $\mathrm{C}$. Com. establece respecto del capitán -y su sustituto, el piloto-, el sobrecargo y el maquinista, sin perjuicio de que, vistas las manifestaciones posteriores del señor $\mathrm{F}$. y las de los demás inculpados, parecía conveniente contrastar tales contradicciones observadas practicando el pertinente careo, como señala la Sentencia apelada.

\section{Comentario}

La Sentencia de 27 de junio de 1980 alcanza sin titubeos la conclusión de que el ptincipio de presunción de inocencia vincula a todos los poderes, siendo de directa aplicación (artículos 24.2 y 53), en un razonamiento que es irreprochable en cuanto expresa que siempre debe presumirse la inocencia, de modo que esta presunción sólo puede destruirse cuando se pruebe lo contrario, sin que pueda invertirse esta presunción obligando a probar la inocencia.

No es tan convincente la alusión a la Constitución para justificar la inadmisión de documentos escritos en lengua diferente a las españolas. El carácter del castellano como lengua oficial del Estado y de las demás lenguas españolas en las Comunidades Autónomas, si así lo disponen sus Estatutos, pudiera ser compatible con la aportación de documentos en lenguas extranjeras. Porque no debe pensarse sólo en la aportación de documentos contra la presunción de inocencia, sino en defensa de la misma. El obstáculo a la admisión de tales documentos sin adveración, autenticación y pertinente traducción se encuentra en el Convenio de Asistencia Mutua entre las autoridades aduaneras de España y la República Federal de Alemania, tal y como se fundamenta en la citada sentencia. 
Núm. 9. Sentencia de 3 de julio de 1980. Contencioso-Administrativo. Sala IV. Ponente, E. Díaz Eimil: ARTICULOS 13 Y 24 DE LA CONSTITUCION.

\author{
Igualdad de derechos sin discriminación de nacionalidades \\ Extranieros \\ Presunción de inocencia
}

La mera denuncia no puede significar responsabilidad penal, ya que esto iría en contra del principio de presunción de inocencia proclamada en el artículo 24 de la Constitución. De otra parte, la Constitución, que consagra los derechos fundamentales, los otorga sin discriminación de nacionalidades.

\title{
Antecedentes
}

Véase Sentencia de 27 de junio de 1980 (núm. 8 de 1980).

ConsIDERANDo: Que, como acertadamente manifiesta el Ministerio Fiscal al evacuar su trámite en este recurso, la resolución administrativa al presente impugnada se basa únicamente en el hecho de que «por investigaciones llevadas a cabo y que constan en el expediente, se pone de manifiesto una conducta irregular por parte del súbdito alemán antes citado»; mas, cuando acudimos a examinar el citado expediente, sólo encontramos un Informe-Propuesta del comisario-jefe provincial de Policía de Castellón, de fecha 24 de agosto de 1979, dirigido al Excmo. Señor Gobernador Civil de dicha provincia, en el que se relatan unas actuaciones relativas a la retirada del pasaporte a petición del Consulado alemán, al parecer por cuestiones fiscales en su nación de origen que no han llegado a determinarse, así como una denuncia presentada contra aquél por un supuesto delito de apropiación indebida relativa a retraso en la devolución de un automóvil alquilado, así como un intento de disolver una sociedad, civil o mercantil, que dicho súbdito extranjero había constituido con el propietario de una discoteca en Benicasim, amén de haber resultado perjudicado en una presunta estafa cometida contra el mismo por una tercera persona, hechos todos ellos de los que la autoridad gubernativa pretende deducir el concepto jurídico indeterminado «conducta irregular» como una de las causas legales que recoge el apartado $10^{\circ}$ del art. 29 del Decreto de 14 de febrero de 1974; pues bien, analizadas dichas bases fácticas a fin de poder determinar si algunas de ellas pueden ser tenidas como integradoras de referido concepto, se observa que, la primera, retirada del pasaporte, se refiere a un hecho, sin que conste la causa desencadenante de referida unilateral medida, así como que la segunda, hasta tanto no exista sentencia judicial, la mera denuncia no puede significar la forzosa responsabilidad penal, y cualquier consecuencia que en tal sentido pudiera presumirse se opone a la presunción de inocencia que proclama el articulo 24 de nuestra Constitución, sin que ello sea olvidar la normativa del apartado $2 .^{\circ}$ del artículo 29 citado; por otra parte, las bases fácticas tercera y cuarta aludidas con su sola mención deben quedar excluidas de toda consideración a estos efectos, pues respectivamente discutibles o acciones punibles de terceros, en las que el actual interesado puede aparecer como víctima o perjudicado.

ConstDerando: Que, atendiendo los supremos presupuestos de la vigente Constitución española, respetuosa con los derechos de la persona sin discriminación de nacionalidades y, en particular el artículo 13 del Pacto Internacional de 19 de diciembre de 1966, ratificado por el Estado español el 19 de abril de 1977, que determina que el extranjero sólo podrá ser expulsado del territorio español en cumpli- 
miento de una decisión adoptada conforme a la Ley y, a menos que razones imperiosas de seguridad nacional se opongan a ello, siempre se le permitirá a dicho extranjero exponer las suyas en contra de tal expulsión así como someter su caso a revisión ante la autoridad competente; pues bien, en el caso presente que nos ocupa no se aprecia ninguna de las causas de los artículos 26 y 29 del Decreto 522/1974, de 19 de febrero, ni del Decreto 1617/1978, de 2 de junio, que la resolución impugnada invoca, ya que incluso del expediente administrativo - como antes se apunta- no se deduce que de su forma de vida, actividades o conducta, y al no existir infracciones en materia de extranjería sea aconsejablemente razonable la adoptación de medida como la aludida de su expulsión del territorio nacional; por todo ello se está en el caso de entender como disconforme a derecho la resolución administrativa al presente combatida, habiéndose de estimar el actual recurso contra la misma interpuesto; y habiéndose ya adoptado las medidas oportunas respecto de la suspensión de la ejecución del acto impugnado, así como en relación a su situación de libertad por los hechos de referencia, sólo nos queda acceder a la petición de dejar sin efecto el acto anulado, sin que haya lugar a resolver sobre la petición de devolución del pasaporte por ser cuestión diferente a la que nos ocupa.

Considerando: Que, a tenor de lo dispuesto en el párrafo 3 del artículo 10 de la Ley 62/1978, al haberse circunscrito la declaración de la situación jurídica individualizada solamente a los supuestos fácticos de referencia, sin que aquélla se refiera a la petición de la retirada del pasaporte y su devolución, como el suplico de la demanda acota, no existen méritos suficientes para hacer una expresa declaración de condena en costas respecto de las derivadas de este proceso jurisdiccional especial.

Resultando: Que contra la anterior Sentencia interpuso apelación el abogado del Estado, que fue admitida en un solo efecto, con emplazamiento de las partes y remisión de los autos a este Tribunal, ante el que se personó, en tiempo y forma, el abogado del Estado, sin que lo haya verificado don F. G. D.; y por providencia de 22 de mayo de 1980 se acordó pasar las presentes actuaciones al señor Magistrado Ponente en las mismas, para la resolución procedente.

Visto, siendo Ponente, el Magistrado Excmo. Sr. D. Eugenio Díaz Eimil.

Vistos la Ley de 26 de diciembre de 1978 sobre protección jurisdiccional de los derechos fundamentales de las personas; el Decreto de 14 de febrero de 1974; el Decreto de 2 de junio de 1978 y demás normas y jurisprudencia aplicables.

Se aceptan los Considerandos de la Sentencia apelada; y

ConsIDERANDo: Que la presente apelación carece en absoluto de fundamentación, pues la Abogacía del Estado la interpone por medio de un escrito que incumple el artículo 9.2 de la Ley de 26 de diciembre de 1978 , en cuanto que en el mismo no se contiene razonamiento de clase alguna que explique o justifique dicho recurso, incidiendo así éste en un defecto procesal, no intentado subsanar en el escrito de personación, que priva a esta Sala de la presencia de una auténtica pretensión revocatoria de la sentencia apelada que venga legalmente articulada, y si a ello se une que en dicha Sentencia no se aprecia infracción de orden público, que, en último término, pudiera justificar su revocación sin faltar a la naturaleza rogada de esta jurisdicción, resulta obligada una decisión confirmatoria que además encuentra sólido apoyo en la acertada interpretación y aplicación que dicha sentencia hace de la legalidad vigente y que le conduce, de acuerdo con la petición del Ministerio Fiscal, a una anulación del acto administrativo recurrido, que merece sin reparo alguno la aceptación de esta Sala. 
Considerando: Que rechazado totalmente el recurso de apelación, procede imponer las costas de esta segunda instancia a la Administración apelante por así ordenarlo el artículo 10.3 de la Ley citada.

\section{Comentario}

La Sentencia de 3 de julio de 1980 reitera el principio de presunción de inocencia, consagrado expresamente en el apartado 2 del artículo 24 . La aplicación de dicho principio determina que la denuncia de una supuesta «conducta irregular» de un ciudadano extranjero no es susceptible de determinar la aplicación del artículo 29 del Decreto de 14 de febrero de 1974.

La Sentencia alcanza la conclusión de que la Constitución española no discrimina a los extranjeros en relación a los españoles en el ejercicio y disfrute de los derechos fundamentales. Esta posición no es, sin embargo, del todo ajustada al texto constitucional. En efecto, el artículo 13 de la Constitución, después de afirmar en su apartado 1 el principio general de equiparación entre españoles y extranjeros, lo subordina a los términos de los tratados y la Ley, y en el apartado 2 establece una concreta limitación en relación al artículo 23 del texto constitucional. Por lo demás, a mi juicio, el criterio de la Sentencia es el adecuado y es de esperar que así se recoja en la Ley de extranjería cuyo Anteproyecto fue aprobado recientemente en el Consejo de Ministros y remitido a las Cortes.

Finalmente cabe destacar que la Sentencia aplica directamente el Pacto Internacional de 19 de diciembre de 1976, ratificado por España el 19 de abril de 1977, sin duda por virtud de lo dispuesto en el artículo 13.1 en relación al artículo 10.2 del texto constitucional.

Núm. 10. Sentencia de 11 de julio de 1980. Contencioso-Administrativo. Sala III. Ponente, F. Roldán Martínez: ARTICULOS 10.1, 19, 20.4, 28.2, 37.2, 53.1, 97 y DISPOSIGION DEROGATORIA 3." DE LA CONSTITU. CION.

Derecho a la buelga: límites

Servicios esenciales: limite a la medida

de conflicto colectivo

El derecho a la huelga no es un derecho absoluto, sino sometido a límites que deben interpretarse restrictivamente de acuerdo con el texto constitucional y tratados internacionales suscritos en la materia pot España.

En especial supone un límite al derecho a la huelga la garantía constitucional de que se asegure el mantenimiento de los servicios esenciales de la comunidad. El derecho a la huelga, que es de directa aplicación, necesita preceptos complementarios de desatrollo y aplicación concreta que lo encaucen, sin que pueda reputarse que tal desarrollo niegue el derecho, sino que lo hace posible.

Considerando: Que al recurso núm. 306.167/80, promovido por el Sindicato Unitario (S. U.), al amparo de la Ley de Protección Jurisdiccional de los Derechos Fundamentales de la Persona de 26 de diciembre de 1978, impugnando el Real Decreto 266/80 de 8 de febrero, y las Circulares núms. 450 y 451 de la Dirección General de Renfe dictadas en aplicación del artículo 2 del expresado Real Decreto y la delegación de atribuciones otorgada en favor del delegado del Gobierno en Renfe, fueron acumulados los recursos núms. 306.169 y $306.170 / 80$, interpuestos respectivamente por la Federación de CC. OO. de Transportes y Comunicaciones de la Confederación Sindical de Comisiones Obreras y por don Manuel Fernández Cachán y otros, miembros del Comité de Empresa de Renfe, por deducirse contra el mismo Real Decreto y Circulares de Renfe dictando normas para asegurar el funcionamiento del servicio ferroviario para que no quedase paralizado por el ejercicio del derecho de huelga por los agentes de Renfe, anunciada por el Comité de 
Empresa de la misma, de setenta y dos horas de duración para los días 20,21 y 22 de febrero de 1980.

Considerando: Que el primer tema a resolver es el de la caducidad de los recursos números 306.169 y 306.170/80 opuesta por el abogado del Estado por haberse formulado las demandas fuera del plazo establecido en el art. 8.4 de la Ley de 26 de diciembre de 1978 de Protección Jurisdiccional de los Derechos Fundamentales, que fija el plazo improrrogable de ocho días, y ser de aplicación supletoria el art. 67.2 de la Ley Jurisdiccional, que con carácter imperativo establece que si la demanda no se hubiese presentado en el plazo concedido, se declarará de oficio caducado el recurso, siendo por ello esta cuestión de examen preferente, ya que de estimarse la caducidad impediría entrar a resolver sobre el fondo de las cuestiones planteadas en ambos recursos por la Federación de CC. OO. de Transportes y Comunicaciones de la Confederación Sindical de Comisiones Obreras y por don $\mathrm{Ma}$ nuel Fernández Cachán y otros miembros del Comité de Empresa de Renfe, aunque en este caso, por tener los tres recursos igual objeto y discutirse las mismas cuestiones de fondo, no suceda así, no relevando a la Sala de su examen y decisión.

Considerando: Que los términos preclusivos fijados por la Ley para el ejercicio eficaz de un derecho que decae fatal y automáticamente en razón objetiva de su no utilización, sin contemplación de causas subjetivas, son plazos de caducidad o decadencia del derecho que la Ley explícitamente determina ante la necesidad de consolidar superiores intereses tenidos en cuenta por el legislador, cual sucede con la caducidad del recurso que el número 2 del artículo 67 de la Ley Jurisdiccional dispone decretar de oficio, por lo que debe ser acordada desde el mismo momento en que se produce la extemporánea presentación de la demanda, por ser claro y terminante el mandato de la Ley, $y$, doblemente, ha de ser respetado y cumplido cuando sobre el efecto jurídico del incumplimiento del plazo procesal se produce, a instancia de parte, solicitando esa declaración de caducidad, que es el supuesto que aquí se contempla, por lo que apareciendo de las actuaciones que el escrito de demanda de la Federación de CC. OO. de Transportes y Comunicaciones de la Confederación Sindical de Comisiones Obreras y del Comité de Empresa de la Renfe fue presentado por el procurador señor Bonilla, con fecha 18 de junio pasado, y que la providencia de esta Sala de 2 de junio fue notificada con fecha 6 del expresado mes, es manifiesto que la demanda de dichos recurrentes se presentó extemporáneamente después de transcurrido el término de los ocho días, por lo que procede declarar los efectos que la Ley señala, solicitados por el abogado del Estado, respecto a ambos recursos, declarándolos caducados por haberse presentado la demanda fuera del plazo establecido, máxime teniendo en cuenta la naturaleza sumaria y urgente que para la tramitación de esta clase de recursos establece el art. 10 de la Ley 62/78 de 26 de diciembre a todos los efectos orgánicos y procesales, por lo que si los plazos de esta naturaleza los concede la Ley, no la Sala ni la Secretaría, es claro que ni los particulares ni el propio Tribunal pueden desvirtuar la legalidad de la notificación practicada conforme a Ley para alterar el plazo, pues, de no ser así, habría que considerar sin contenido los preceptos que así lo imponen, quedando a merced de los interesados la ampliación indefinida de los plazos.

Considerando: Que encontrándose una de las notas esenciales del Estado de Derecho en el axioma de la sumisión de la actividad administrativa al ordenamiento jurídico preestablecido, y en que si éste axioma es quebrantado por una actividad administrativa - que se manifiesta en disposiciones generales y actos administrativos-, es abiertamente opuesta a una norma jurídica de rango superior, pueda ser estimada y declarada por los Tribunales disconforme a derecho, siendo el problema 
de fondo que se plantea en este procedimiento de protección a los derechos y libertades fundamentales en vía judicial previa al amparo constitucional, definir si el Real Decreto 266/80 de 8 de febrero, y las circulares ya citadas, contienen normas que vulneren el derecbo a la buelga garantizado a los trabajadores como derecho fundamental por el artículo 28.2 de la Constitución, en los términos limitados que según el texto literal del indicado precepto que: «Se reconoce el derecho a la buelga de los trabajadores para la defensa de sus intereses. La Ley que regule el ejercicio de este derecho establecerá las garantías precisas para asegurar el mantenimiento de los servicios esenciales de la comunidad», procede examinar en primer lugar la cuestión referente a la inconstitucionalidad del mencionado Real Decreto, para lo que conviene comenzar puntualizando que toda norma constitucional deberá ser interpretada no aisladamente, sino dentro del conjunto o sistema del contexto general de la Constitución, y que en materia de limitaciones de un derecho fundamental la interpretación ba de bacerse con criterio restrictivo a fin de no imponer a las personas otras limitaciones, en el ejercicio de sus derechos fundamentales, que las que exijan el bien común y el respeto a los derechos de las demás, como así se recoge en el numero 1 del artículo 10 del propio texto constitucional, señalando en el numero 2 de este mismo artículo 10 que las normas relativas a los derechos fundamentales $y$ a las libertades que la Constitución reconoce se interpretarán de conformidad con la Declaración Universal de Derechos Humanos y los Tratados y Acuerdos Internacionales sobre las mismas materias ratificadas por España; sin duda, a causa de la ausencia de precedentes en nuestra historia constitucional, pero del examen de los textos de las Declaraciones Universales de los Derechos Humanos, en orden al reconocimiento de estos derechos y sus garantías, $\mathrm{y}$, en forma más concreta, del derecho de los trabajadores a la huelga, es el de consagrarlos de modo expreso sistemático en las Constituciones, estableciendo limitaciones o restricciones en beneficio de la comunidad, valorando los nuevos derechos sociales y económicos de la misma manera que los clásicos a la libertad y la igualdad, en la Declaración Universal de los Derechos del Hombre, formulada por las Naciones Unidas en 1948 pueden señalarse como características principales, aparte de su fundamentación en el principio filosófico-jurídico de la dignidad de la persona humana, la contenida en el artículo 29.2 que al hablar de las limitaciones a las libertades de la persona incluye, con carácter general, las que se deriven de las justas exigencias de la moral, del orden público y del bienestar general de una sociedad democrática, a partir de cuya Declaración de 1948 se han ido celebrando Pactos y Convenciones Internacionales sobre Derechos Humanos como los adoptados por la Asamblea General de las Naciones Unidas en 16 de diciembre de 1966, uno para los derechos civiles y políticos y otro para los derechos económicos, sociales y culturales; los acuerdos a nivel regional, como la Convención Europea para la Salvaguardia de los Derechos del Hombre, del Consejo de Europa, firmada en Roma en 1950, en todos ellos se reconocen los derechos llamados fundamentales y sus garantías mediante un control jurisdiccional, habiendo sido recogidos en las leyes constitucionales de los Estados signatarios tanto los llamados derechos innatos a la persona como los adquiridos por el ciudadano y el trabajador, reconocidos constitucionalmente como fundamentales, pero ninguno de ellos tiene carácter absoluto ni ilimitado, sino que están limitados en cada sistema jurídico por las exigencias del bien general y la coexistencia con los ottos derechos de los demás, pudiendo afirmarse en este sentido que la existencia de la comunidad estatal, con sus necesidades, pone límites a los derechos fundamentales. Solo en la Declaración de Derechos, como la francesa de 1789, se les formula como absolutos, por lo cual esta Sala no puede compartir el criterio de considerar absolutos e ilimitados tales derechos, por lo que al resolver sobre la legalidad del Real Decreto impugnado debe tenerse presente que el reconocimiento constitucional del derecbo a la buelga necesita de preceptos complementarios de 
desarrollo $y$ aplicación concreta, sin que pueda alegarse que por el becho de que tales preceptos o normas complementarias encaucen las libertades que la Constitución reconoce, nieguen éstas o sean contrarios e incompatibles con los mencionados derechos básicos de la persona, pues, de entenderlo así, también se llegaría a la absurda consecuencia de estimar en contradicción con el fundamental derecho de ir y venir o libre circulación por todo el territorio nacional, que es una de las libertades más fundamentales, con la reglamentación municipal sobre circulación urbana y la aplicación del Código de la Circulación, por ser manifiesto que tanto uno como otro ponen limites a la libre circulación, pero es evidente que lo hacen precisamente para confirmar el derecho de ir y venir; lejos de contradecir el derecho fundamental, lo reafirman al posibilitar su ejercicio; de una coordenada contemplación de los artículos 10.1 y 20.4 del texto constitucional no se puede dudar que los derechos fundamentales y libertades públicas tienen sus limites en el respeto a los derecbos reconocidos a los demás en el Título I y en las Leyes que los desarrollen, y consiguientemente también el derecho de los trabajadores a la buelga.

Considerando: Que si bien es cierto que las Constituyentes del 78, al establecer las garantías, determinaron en los artículos 28.2 y 53.1 que sólo por Ley podrá regularse el ejercicio de los derecbos y libertades reconocidos en el Título I, capítulo II, establecieron por tanto la reserva de Ley para regular los derecbos fundamentales, entre los que se encuentra el derecho de buelga, estableciendo el articulo 81.1 que son leyes orgánicas las relativas al desarrollo de los derechos fundamentales y de las libertades públicas; la garantía establecida fue de una ley orgánica, y cierto también que el Decreto que se impugna no reune la categoría de Ley, se trata de un Decreto del Gobierno, pero siendo el derecho de buelga que consagra el artículo 28.2 de aplicación inmediata y directa por los Tribunales como por todos los poderes públicos, según asi lo dispone el artículo 53.1, es incuestionable, como lo reconoce expresamente el Sindicato Unitario (S. U.), en el fundamento undécimo de su demanda, que al no existir la Ley que desarrolle el derecbo a la buelga ante la falta de desarrollo legislativo, necesariamente babría que optar o por no dar efectividad al derecbo de buelga proclamado basta que se promulgase la Ley que regule su ejercicio o establecer las limitaciones valiéndose de una normativa legal vigente, por no alcanzarle la cláusula derogatoria $3 .^{a}$ de la Constitución, como es el Real Decreto-Ley de 4 de marzo de 1977, que sirve de cobertura legal vigente en cuanto su Título I está reconocido en la Ley posterior que aprobó el Estatuto de los Trabajadores de 10 de marzo de 1980, como así lo establece el número 15 de la disposición final tercera, por lo que al haber sido ratificado dicho Decreto-Ley y apoyarse en sus preceptos el Real Decreto que aquí se impugna, dictado en uso de la autorización concedida en la disposición final cuarta del citado Real Decreto-Ley de 4 de marzo de 1977, haciendo una interpretación siguiendo la línea del párrafo segundo del artículo 10, sus normas deben ser aplicadas mientras no sea desarrollada la Constitución con la Ley reguladora del derecbo a la buelga acorde con las limitaciones establecidas en las leyes nacionales de los demás paises y el respeto a la propia Constitución, al ejercicio de los derechos reconocidos en ella a los demás, y protección en definitiva de los superiores intereses de la comunidad nacional, siendo incuestionable que debe recbazarse toda solución que conduzca al absurdo, como sería aceptar las pretensiones que en definitiva laten en el fondo de la presente impugnación, de declarar el derecbo a la buelga con carácter absoluto, pues ello conduciría a la negación del derecbo proclamado como básico e impediría el ejercicio por los demás, de los restantes derechos fundamentales que la Constitución reconoce y garantiza.

Considerando: Que el Real Decreto impugnado de 8 de febrero de 1980, como se expresa en su preámbulo, fue dictado exclusivamente para garantizar el funcio- 
namiento del servicio público ferroviario, encomendado a la Renfe, para que, en cualquier situación de huelga de su personal, no quedase paralizado el servicio, $l i$ mitando su mantenimiento a lo esencial, ajustadamente a lo así dispuesto en el número 2 del artículo 28 de la Constitución española; por ser manifiesto que el servicio ferroviario de Renfe es uno de los servicios públicos esenciales de la comunidad nacional, que no es absoluto, y que no existe Ley específica que lo desarrolle, el Decreto se limitó a tutelar el derecbo básico de buelga en los propios términos establecidos en el texto constitucional a la vez de posibilitar el ejercicio de los demás derechos reconocidos a los españoles, por lo que no se puede estimar que el referido Real Decreto en derecbo material contradiga o sea opuesto a la Constitución de 27 de diciembre de 1978, por ser incuestionable que si no se ba desarrollado la Constitución, en la regulación de la buelga, el Estado, que tiene como misión primordial defender a la población y el territorio no puede quedar indefenso y tiene que arbitrar alguin medio para asegurar el mantenimiento de los servicios esenciales de la comunidad nacional y a la vez se pueda ejercer el derecbo a la buelga; la falta de esa Ley orgánica proclamada por la Constitución sólo puede ser subsanada con la normativa vigente aplicada, el Real Decreto-Ley de 4 de marzo de 1977, cuyo rango normativo es en sentido formal una Ley ordinaria, y que al no estar en contradicción con el texto constitucional, no se le puede considerar derogado por la disposición derogatoria $3 .^{a}$ de la Constitución; en último término, ante una situación económica grave por una paralización del tráfico ferroviario, el becbo es que el Gobierno, al amparo del artículo 97 de la Constitución, apoyándose en el DecretoLey de 4 de marzo de 1977, baya becho uso de la potestad reglamentaria adoptando medidas para mantener el servicio de la Renfe sin salirse del marco constitucional, justifica la promulgación del Real Decreto de 8 de febrero de 1980 sin que para la cuestión de fondo que se debate tenga mayor trascendencia que el artículo $28.2 \mathrm{ba}$ ble de establecer las garantías precisas para asegurar «el mantenimiento» de los servicios esenciales, y en el artículo 10 del Real Decreto-Ley de 4 de marzo de 1977 y en el Real Decreto de 8 de febrero de 1980 y la Circular núm. 450 se diga asegurar el «funcionamiento» del servicio público ferroviario, pues tanto en uno como en el otro texto de lo que en definitiva se trata es la de habilitar para tomar las medidas «necesarias» - nada más que las necesarias-, siendo equivalentes las dos acepciones, «mantenimiento» o «funcionamiento» de los servicios esenciales, como lo prueba de una manera auténtica la indiferencia con que el legislador utiliza ambos vocablos en el propio texto constitucional, pues si en el artículo 28.2 babla de «mantenimiento», en el 37.2 , refiriéndose a un supuesto análogo de limitaciones $y$ garantías que deberán establecerse en la Ley que regule el ejercicio del derecho de los trabajadores en los casos de conflicto colectivo, dice que se incluirán aquellas garantías precisas para asegurar el funcionamiento de los servicios esenciales de la comunidad; como se ve, lo que el legislador quiso decir y expresó en ambos supuestos fue simplemente su voluntad de que las limitaciones a las libertades, derecbos fundamentales reconocidos, cuando se trate o afecte a una empresa de servicios públicos no cabe establecerlas con interpretaciones extensivas, sino que deben bacerse con sentido restrictivo, o sea, sólo las precisas para respetar los otros derechos reconocidos a los demás y posibilitar asi su ejercicio por la comunidad nacional.

Considerando: Que la última cuestión a resolver es la referente a la legalidad o ilegalidad de las dos Circulares impugnadas, números 450 y 451, apreciación que ba de bacerse en confrontación con las disposiciones superiores, que son las establecidas en el tan repetido artículo 28.2 de la Constitución y en el Real Decreto de 8 de febrero de 1980, al disponer el primero que la Ley que regule el ejercicio del derecho a la buelga establecerá las garantías precisas para asegurar el mantenimiento de los servicios esenciales, y establecer el segundo que la buelga que afecte al personal 
de la Renfe se condicione a mantener el servicio de transporte ferroviario esencial; las dos Circulares ban sido dictadas por la Dirección General de la Renfe, y aunque el abogado del Estado alega la incompetencia de la jurisdicción para resolver sobre su impugnación, por estimar que no son actos administrativos, porque la Red Nacional de los Ferrocarriles Españoles no es un órgano administrativo ni una entidad estatal autónoma y su reglamentación orgánica sólo autoriza la impugnación en esta vía jurisdiccional de los acuerdos de la Delegación del Gobierno al resolver las alzadas contra actos de la Renfe; pero tal alegación debe ser rechazada, porque, aun siendo cierto que la Red Nacional de los Ferrocarriles Españoles sea propiedad del Estado y constituya un patrimonio dotado de personalidad jurídica propia y distinta de la de aquél, no cabe desconocer que aunque sea una empresa industrial fue creada para la explotación de un servicio nacional en régimen de gestión como empresa privada, por lo que, en cuanto es gestora de un servicio público, tiene el carácter de administración pública en la prestación del servicio, en la contratación y en la administración; su presupuesto y financiación, además, se nutre de los del Estado; entrando ya en el estudio de las dos Circulares impugnadas del Centro Directivo de Renfe, vemos que no hacen más que transcribir sendas resoluciones de la Delegación del Gobierno: la 450 contiene instrucciones sobre el Plan Esencial de Transportes a aplicar en la red ferroviaria en cualquier supuesto de huelga, y la 451 aprobando la aplicación del nivel 2 a la situación de huelga convocada para los días 20, 21 y 22 de febrero de 1980; antes de entrar a examinar la posible extralimitación de las mismas debe tenerse presente que en Derecho administrativo, en cuanto no exista un precepto expreso que la prohíba, la competencia de un órgano o agente puede delegarse, y en los casos de extrema urgencia la incompetencia puede subsanarse por la ratificación ulterior del acto o disposición por la autoridad competente; lo que no puede hacerse válidamente es renunciar a la competencia en provecho o favor de un subordinado.

Considerando: Que la lectura de ambas Circulares pone de manifiesto que ninguna de las dos es interpretativa de disposiciones superiores, no alteran ni modifican abiertamente el texto constitucional ni el contenido del Real Decreto 266/80 de 14 de febrero, no son, pues, en sentido formal un grado más de la jerarquía de las normas, sino simple manifestación de la jerarquia administrativa de carácter interno para determinar el modo de proceder de los subordinados jerárquicos; la Circular 40 pone en conocimiento de todos los agentes cuál es el Plan Esencial de Transportes a aplicar en la red en caso de huelga, y la Circular número 451 comunica las instrucciones a seguir para aplicar el nivel 2 autorizado por el delegado del Gobierno con motivo de la convocatoria de huelga de setenta y dos horas anunciada para los días 20, 21 y 22 de febrero de 1980; conforme a lo dispuesto en el apartado $f$ ) de la Circular 450, ninguna de las dos Circulares infringe el texto del artículo 28.2 de la Constitución ni se extralimitan de lo que permite el Real Decreto de 8 de febrero de 1980 , el cual, en su artículo $1 .^{\circ}$, establece que «cualquier situación de huelga que afecte al personal de la Renfe se entenderá condicionada a que se mantenga el servicio de transporte esencial»; el artículo 2, «que la Delegación del Gobierno será la que determine, con carácter restrictivo, el personal estrictamente necesario para asegurar la prestación del servicio de transporte ferroviario esencial», acreditado por la prueba documental incorporada al expediente que fue la Delegación del Gobierno en Renfe - no la Dirección General de esta empresa- la que fijó el nivel intermedio 2 para aplicar a la huelga general de tres días; si se tiene en cuenta que la prestación del servicio por la aplicación de dicho nivel número 2 supuso un total de agentes afectados de 14.256, agentes impedidos de ir a la huelga, frente a la cifra de 72.000 personas trabajadoras en Renfe, por lo que resulta haberse respetado el derecho a la huelga de cerca de 
60.000 trabajadores; infiriéndose de estas cifras no haber rebasado los límites razonables de mantenimiento del servicio de transporte ferroviario esencial; las 14.000 personas necesarias para la prestación de ese nivel de servicios esenciales es independiente de la duración de la huelga, tenga ésta una duración de tres días o de cuatro horas; no varía la necesidad del número de agentes precisos para la explotación o mantenimiento de los servicios mínimos esenciales durante toda la jornada, por. lo que, si se admiten limitaciones al derecho de huelga, no puede negarse el derecho del Estado a adoptar las medidas mínimas indispensables, y como de la prueba aportada no resulta que las restricciones a la circulación ferroviaria superasen las limitaciones esenciales que el texto constitucional autoriza, procede la desestimación del recurso.

\section{Comentario}

La Sentencia de 11 de julio de 1980 es la primera dictada por el Tribunal Supremo sobre el derecho de huelga con posterioridad a la promulgación de la Constitución. Posteriormente, en idéntica línea jurisprudencial, y durante el año 1980, el Alto Tribunal ha dictado tres sentencias más sobre la misma materia. Por otra parte, en este momento está pendiente el Tribunal constitucional de dictar una sentencia sobre el Real Decreto-Ley de 4 de marzo de 1977, que sirve de fundamento legal al Real Decreto y Circulares objeto de este recurso. La sentencia que comentamos aborda una serie de cuestiones a propósito de pronunciarse sobre la constitucionalidad del Real Decreto 266/80 de 8 de febrero y las Circulares núms. 450 y 451 del Ministerio de Trabajo, de las que queremos resaltar algunas en este lugar. Son presupuestos de que parte la sentencia el de que no pueden concebirse los derechos fundamentales sin límites, pero éstos deben recibir una interpretación restrictiva. Por otra parte, la interpretación de los derechos fundamentales debe hacerse conforme a los tratados internacionales suscritos por España en la materia, como preceptúa el apartado 2 del artículo 10. Hasta aquí la sentencia alcanza conclusiones que se deducen transparentemente del texto constitucional y sobre las que la doctrina ha insistido reiteradamente.

A partir de las conclusiones anteriores, se afirmará que la regulación del derecho de huelga no debe entenderse sino como cauce para su ejercicio, afirmación que no está desprovista de exactitud, dándose la circunstancia de que el propio artículo 28.2 prevé que se dicte una ley reguladora del derecho de huelga que debe contemplar necesariamente el conjunto de garantías precisas para asegurar el mantenimiento de los servicios esenciales de la Comunidad. Pero esta previsión no puede entenderse en el sentido de que el derecho no sea ejercitable directamente a partir de la Constitución, sino que la índole del derecho hace especialmente necesario el desatrollo legislativo habida cuenta de los límites que se prevén, lo que en caso alguno, insiste la sentencia, significa que la falta de desarrollo constitucional impida el ejercicio directo del derecho como parece desprenderse del $50^{\circ}$ considerando, en que se advirte cierta contradicción en los términos.

Otro de los temas que se plantean es el del rango de la disposición de desarrollo del artículo 28.2 conectado con el artículo 53.1, la disposición derogatoria 3. ${ }^{\mathrm{a}}$ y el Real Decreto-Ley de 4 de marzo de 1977.

No parece dudoso que el rango de la disposición de desarrollo del artículo 28.2 debe ser el de Ley orgánica, punto sobre el que no vamos a insistir por ser pacífico en la doctrina. El problema radica en calibrar el Real DecretoLey de 4 de marzo de 1977, que sirve de fundamento al Decreto y Circulares impugnados en el sentido de establecer su vigencia con relación al texto constitucional.

El argumento utilizado en la sentencia del que podría deducirse que el Estatuto de los Trabajadores viene a confirmar la constitucionalidad del citado Decreto-Ley es inconsistente. Las Leyes, aun proviniendo del poder legislativo, no son patente de corso que obvien el examen sobre la constitucionalidad de otras normas o de ellas mismas.

Pero siendo cierto lo anterior, no lo es menos que la circunstancia de que el DecretoLey de 4 de marzo de 1977 sea anterior a la Constitución no implica de por sí que haya sido derogado por oponerse a la Constitución o que devenga inconstitucional. En el caso de que su contenido no fuera inconstitucionalidad, no obstante, cabe plantearse su vigencia dada la reserva de ley orgánica que se deduce de los artículos 28.2, 53.1 y 81.1 del texto 
constitucional. A mi juicio, si bien resulta evidente que no puede dictarse esta legislación en directo desarrollo del texto constitucional, con posterioridad a la vigencia de éste, si ésta no es de carácter orgánico (aunque esto ha tenido lugar, véase E. Linde, Anotaciones a los Decretos-Leyes de convocatoria de los referéndums autonómicos en el País Vasco y Cataluña: vigencia de la Constitución y reserva de la Ley orgánica, en RAP, núm. 89). La duda surge cuando lo que tiene lugar es el desarrollo y posteriormente la aplicación de una norma anterior a la Constitución, como es el Decreto-Ley a que nos hemos referido. A nuestro juicio, en el caso de que el Decreto-Ley pueda reputarse conforme a la Constitución permanecerá vigente en tanto no se dicta la correspondiente Ley orgánica de desarrollo del artículo 28.2 del texto constitucional, pero los desarrollos del Decreto-Ley y sus actos de aplicación no sólo deberán ser estrictamente conformes a aquel, sino al texto constitucional en su conjunto. Esto es, la legalidad del Decreto de 8 de febrero de 1980 y Circulares de aplicación no depende sólo de su adecuación al Decreto-Ley que le sirve de base, sino a su adecuación a la Constitución y especialmente a los tratados internacionales suscritos por España en la materia. A los Tribunales corresponde hacer esta verificación.

Sobre el tema de la huelga contamos con amplia bibliografía, entre la que destacamos:

G. Barreito González, La disponibilidad del derecbo de buelga y su garantía en la Constitución, en «Revista de Política Social», núm. 121, 1979, págs. 75 a 91; A. Martín Valverde, El derecbo de buelga en la Constitución de 1978, cit., págs. 227 a 253; íd., Regulación de la buelga en la Constitución, en «Los trabajadores y. la Constitución», 1980, páginas 201 a $210 ; \mathrm{A}$. Baylos Grau, Notas laborales. Una propuesta sindical de autorregulación de las buelgas, en «R. F.D.U.C.M.», núm. 59, 1980, págs. 167 a 175; W. Däubler, La buelga en la Constitución española, en «Los trabajadores y la Constitución», cit., páginas 83 a 92, y L. E. de la Villa Gil, Algunas reflexiones para la regulación legal de la buelga, en «Estudios de Derecho del trabajo en memoria del profesor Gaspar Bayón Chacón», Madrid, 1980 , págs. 95 a 118.

Núm. 11. Sentencia de 24 de septiembre de 1980. Contencioso-Administrativo. Sala III. Ponente, J. L. Ruiz Sánchez: ARTICULO 53.2 y SECCION 1., CAPITULO II, TITULO I, DE LA CONSTITUCION.

\section{Tutela de derechos y libertades}

Mera cita en su considerando segundo del artículo 53.2 y sección $1{ }^{\text {a }}$, capítulo II del título I en conexión con la Ley 62/1978 (y el Real Decreto de 20 de febreto de 1979) de Protección Jurisdiccional de los Derechos Fundamentales de la Persona.

Considerando 2.0: Que expuesto lo que constituye la esencia de la actividad de raciocinio de las partes, es preciso destacar que, en el ámbito estricto y restringido de este incidente, no procede analizar si las pretensiones de los recurrentes tienen o no acogida en el tipo de proceso creado por la Ley 62/1978 para garantizar aquellos derechos que son objeto de específica enunciación por el artículo 1.2, más tarde ampliados por el Real Decreto de 20 de febrero del pasado año y recogidos por los artículos 14 al 20 de la Constitución; circunstancias excluyentes que también afectan a la invocada falta de legitimación, ya que no se puede prescindir de la naturaleza misma del incidente que examinamos, y la legitimación, no lo debemos olvidar, constituye o es la aptitud de ser parte en un proceso concreto, aptitud que viene determinada por la posición en que se encuentre o encuentren respecto de la pretensión procesal, de modo que se derive o deduzca una idoneidad en relación con el problema de fondo a discernir; es, pues, un problema procesal ligado con el derecho material, máxime cuando la posibilidad sanatoria en el proceso principal puede llegar a lograrse, de no estar justificada, a través de los artículos 62.2 o 129 de la Ley reguladora de esta jurisdicción, a cuyo concurso es preciso adicionar la orientación espiritualista con que la jurisprudencia ha concebido la «legitimación activa», ello sin perjuicio del carácter de los derechos que son objeto de contemplación y de especial tutela, pues o bien se admite en él la acción pública ciudadana al amparo del artículo 53.2 de la Constitución, o bien babría que partir de la idea 
de que quien reclama a través de este procedimiento especial es porque, «prima facie», lo necesita como medio para amparar o proteger su libertad, concepto que tiene una valoración que, cuando se estima coartada, debe ser objeto de concreción según las circunstancias concurrentes y la concepción que se establezca por norma adecuada, por todo lo cual bay que recbazar este obstáculo invocado.

Núm. 12. Sentencia de 24 de septiembre de 1980. Contencioso-Administrativo. Sala III. Ponente, F. Roldán Martínez: TITULO I, CAPITULO II, SECCION 1., ARTICULOS 28.2, 37, 53.1 DE LA CONSTITUCION.

Derecbo de buelga: limites

Servicios esenciales: limite a la medida de conflicto colectivo

El derecho a la huelga no es un derecho absoluto, sino sometido a límites que deben interpretarse restrictivamente de acuerdo con el texto constitucional y tratados internacionales suscritos en la materia por España.

En especial supone un límite al derecho a la huelga la garantía constitucional de que se asegure el mantenimiento de los servicios esenciales de la comunidad. El derecho a la huelga que es de directa aplicación necesita preceptos complementarios de desarrollo y aplicación concreta que lo encaucen, sin que pueda reputarse que tal desarrollo niegue el derecho, sino que to hace posible.

\section{Antecedentes:}

Véase Sentencia de 11 de julio de 1980 (núm. 10 de 1980 de este Repertorio).

CONSIDERANDo: En cuanto a las causas de inadmisibilidad formalmente opuestas por Renfe y sustancialmente indicadas por la abogacía del Estado: a) que las Circulares 450 y 451 , objeto directo de las pretensiones del recurso, aunque se presenten como emanadas de la Dirección General de aquella entidad, que efectivamente está sujeta a régimen jurídico privado, no son sino la explicitación de dos resoluciones de la Delegación del Gobierno: la primera impartiendo instrucciones que integraban un Plan Esencial de Transportes a aplicar en la Red en cualquier supuesto de huelga, y la segunda aprobando la propuesta de Renfe para aplicar el nivel 2 a la situación de huelga convocada para los días 20,21 y 22 de febrero último; y ambas resoluciones constituyen evidentemente manifestaciones típicas de una potestad administrativa no sólo por el encuadramiento orgánico y funcional de la Delegación del Gobierno en Renfe, sino, más concretamente, por serlo de la competencia atribuida en el artículo 2. ${ }^{\circ}$ del Real Decreto 288/1980 de 8 de febrero, sobre cuyo carácter jurídico-administrativo no puede abrigarse duda alguna; esta observación conduce, en suma, a advertir que las pretensiones del recurso versan sobre dos resoluciones del delegado del Gobierno en Renfe formalmente exteriorizadas; en cuanto atañe al personal de este organismo, a través de otras tantas Circulares de la Dirección General de esta entidad, y conduce también a dejar señalado desde este momento que toda posible extralimitación de las Circulares en cuanto a las instrucciones recibidas participaría, en orden a su efectividad, de esa misma naturaleza, siendo tal extralimitación tema distinto y que, en su caso, debe ser tratado como el ejercicio indebido de potestades administrativas o como el ejercicio por delegación de esas mismas potestades; b) que, por virtud de lo dispuesto en el artículo 41.1 de la Ley Orgánica del Tribunal Constitucional, en relación con la disposición transitoria segunda, dos, el procedimiento de protección de los derecbos y libertades fundamentales en vía judicial previa al amparo constitucional se extiende a todos los artículos 14 al 29 de la Constitución; c) que, según lo que de estos preceptos 
se desprende, en relación con el apartado 2 del mismo articulo 41, la protección se otorga también frente a las «disposiciones»; d) que el recurso contencioso-administrativo que pende ante la Sala Tercera del Tribunal Supremo contra el Real Decreto 288/1980 no impide a esta Sala el examen del único problema que se ajusta a esta especifica modalidad de fiscalización jurisdiccional, cuyo problema se define de modo muy simple, puesto que se trata de comprobar si las normas contenidas en las Circulares vulneran -o no- el derecho a la ouelga garantizado por el artículo 28.2 de la Constitución. De ahí que haya que prescindir de todos los óbices de admisibilidad y pasar de inmediato a la cuestión de fondo, tal como acaba de delimitarse.

Resultando: Que contra dicha sentencia se interpuso por el abogado del Estado y la representación de la Red Nacional de los Ferrocarriles Españoles el presente recurso de apelación, en el que, tras el correspondiente emplazamiento, comparecieron dichas partes apelantes ante este Tribunal Supremo, así como la representación del Sindicato Unitario (S. U.) en concepto de apelado.

Siendo Ponente el Magistrado Excmo. Sr. D. Fernando Roldán Martínez.

SE ACEPTA el Considerando primero de la sentencia apelada, y

Considerando: Que la validez o nulidad de los actos y disposiciones administrativas depende de sus cualidades esenciales y de su licitud o legalidad intrínseca en conformidad a las normas de derecho material; en el caso que se enjuicia, el tema objeto de debate de la primera instancia al que se refiere la presente apelación es el de la legalidad de las dos Circulares números 450 y 451 , de fechas 14 de febrero de 1980 y 15 de febrero de 1980 respectivamente, adoptando medidas para asegurar el servicio de transporte ferroviario esencial y en condiciones de seguridad en los supuestos de huelga, conteniendo a tal fin instrucciones dictadas por la Delegación del Gobierno en Renfe, en desarrollo del Real Decreto de 8 de febrero de 1980, Decreto cuya legalidad fue ya declarada por esta Sala en sentencia de 11 de julio de este mismo año, resolviendo recurso promovido al amparo de la Ley de 26 de diciembre de 1978 de Protección Jurisdiccional de los Derechos Fundamentales de la Persona, por estimar este Tribunal en dicha Sentencia de 11 de julio último que las disposiciones del Real Decreto de 8 de febrero de 1980 se ajustan al marco de las garantías constitucionales reguladoras del ejercicio del derecho a la buelga, conforme a los términos limitados en que fue proclamado el reconocimiento de este derecho en el texto constitucional, revocando también dicho recurso sobre las dos Circulares mencionadas números 450 y 451 de la Dirección General de la Renfe, conteniendo la primera instrucciones de la Delegación del Gobierno en dicha empresa nacional de ferrocarriles y estableciendo la segunda, previa autorización del expresado delegado del Gobierno, el nivel de servicio aplicable con motivo de la convocatoria de huelga ferroviaria de setenta y dos horas anunciada para los días 20,21 y 22 de febrero del año actual.

Considerando: Que, por lo que se deja expuesto, resulta manifiesto que sobre esta cuestión ya tuvo ocasión de pronunciarse la Sala en la aludida Sentencia de 11 de julio pasado, estimando la validez formal y material de las dos citadas Circulares por existir dentro de nuestro ordenamiento positivo norma habilitante que posibilita al delegado del Gobierno en Renfe a dictar y aprobar instrucciones de servicio en lo que concierne a la interpretación y aplicación del Real Decreto de 6 de febrero de 1980 -el art. $2^{\circ}$ del mismo- en orden al mantenimiento o funcionamiento del servicio ferroviario en los casos de huelga en los límites precisos para posibilitar el ejercicio por los demás de los otros derechos fundamentales reconocidos por el texto constitucional a la comunidad nacional, singularmente el más fundamental de circular libremente por el territorio nacional; ambas Circulares en su 
contenido sólo tienen medidas de orden interior; no se trata de disposiciones normativas de rango inferior, pues sólo contienen medidas de planteamiento concreto o instrucciones de servicio para asegurar el funcionamiento del servicio público ferroviario, que no puede quedar paralizado por el ejercicio legítimo del derecho de huelga. Tales instrucciones fueron dictadas por la Delegación del Gobierno para desarrollar el artículo 2. ${ }^{\circ}$ del citado Real Decreto de 6 de febrero de 1980, siendo todas ellas indispensables para el mantenimiento del servicio de transporte ferroviario esencial, por lo que tanto una como otra Circular son simples manifestaciones de la jerarquía administrativa, prescripciones que se dan a los funcionarios o agentes de la Renfe colocados bajo la autoridad de su director general concernientes a la aplicación e interpretación del Real Decreto que se deja citado; no contienen reglas de Derecho, sino que se limitan a indicar a los agentes de Renfe cómo deben entender y aplicar aquel Real Decreto, teniendo, pues, un efecto de orden interior, sin encubrir auténticas normas reglamentarias, y no traspasan las fronteras ni restringen las limitaciones establecidas en el texto constitucional para el ejercicio del derecho a la huelga; no crean una obligación o regla nueva que no esté implícita o explícitamente establecida en el Real Decreto de 8 de febrero de 1980, cuya cobertura legal, por otra parte, está asegurada por la vigencia del artículo 10, párrafo $2^{\circ}$, de la Ley 17/77, como expresamente se reconoce en la sentencia apelada, en cuanto babilita a la autoridad administrativa para acordar las medidas necesarias para asegurar «el funcionamiento de los servicios de reconocida e inapelable necesidad» dentro del contexto que imponen los artículos 28.2, 37 y 53.1 de la Constitución, deduciéndose de este reconocimiento que no es aceptable la distinción que el Tribunal «a quo» bace entre «mantenimiento» $y$ «funcionamiento» del servicio, para llegar a consecuencias que no son compartidas por esta Sala de apelación por entender que los vocablos «mantenimiento» que utiliza el articulo 28.2 y el de «funcionamiento» que emplea el artículo 37 del texto constitucional, referidos ambos para asegurar los servicios esenciales de la comunidad, son conceptos equivalentes de igual significado utilizados por el legislador indistintamente para expresar en todo caso que se tomarian las medidas «necesarias» en la Ley que regule el ejercicio del derecho a la buelga para asegurar los servicios esenciales afectados, debiendo significarse, por otra parte, que incluso el vocablo «mantenimiento» expresa una idea más amplia que la de «funcionamiento», por ser evidente que el mantenimiento de un servicio ferroviario precisa del funcionamiento de determinados elementos técnicos para su conservación y puesta a punto o que no estén sin funcionar; por todo ello, resulta claro que si la norma habilitante para dictar Circulares e instrucciones de servicio la Delegación del Gobierno en Renfe existe, pues el artículo 2. ${ }^{\circ}$ del Real Decreto de 8 de febrero de 1980, que autoriza a la Delegación del Gobierno a determinar «con carácter restrictivo el personal estrictamente necesario para asegurar la prestación del servicio de transporte. ferroviario esencial, así como su prestación en condiciones de máxima seguridad», al dictar el delegado del Gobierno, en función de tal delegación de atribuciones, las expresadas Circulares, su actuación quedó formalmente legitimada y el contenido de las mismas se ajusta a derecho, por limitarse a dar cumplimiento a lo dispuesto en el artículo $2 .^{\circ}$ del Real Decreto mencionado, por mantenerse tales instrucciones dentro del espíritu que informa el artículo $10^{\circ}$ del Decreto, en cuanto establece que «cualquier intervención de buelga que afecte al personal de la Red Nacional de los Ferrocarriles Españoles se entenderá condicionada a que se mantenga el servicio ferroviario», precepto que no bace sino recoger lo dispuesto en el artículo 28.2 de la Constitución; y al aplicar el nivel 2 para el mantenimiento del servicio de transporte ferroviario, teniendo en cuenta que la huelga prevista era total y de tres días de duración, las Circulares han ponderado y tenido en cuenta todas las circunstancias que se consignan en el apartado o letra $f$ ) de la Circular 450 para establecer el nivel del Plan Esencial de 
Transportes aplicable al caso, como lo revela, según ya fue señalado por la Sentencia de 11 de julio de esta Sala en su penúltimo Considerando, que el número de agentes afectados fue de 14.256 , frente a la cifra total de 72.000 agentes de Renfe, por lo que no es de apreciar la aplicación extensiva de las medidas adoptadas, al ser casi 60.000 los agentes que pudieron ejercitar el derecho a la huelga, por lo que debe ser revocada la sentencia apelada por no estar probada la trascendencia que el Tribunal a quo aprecia para decretar la nulidad de las Circulares en ausencia de prueba que desvirtuase el criterio técnico seguido por la Administración para asegurar el mantenimiento del servicio ferroviario que fijase el «servicio mínimo esencial» para garantizar a la comunidad, en el caso concreto de la huelga, si procedía el nivel 1 o el nivel 2 aplicado determinando los servicios realmente necesarios en relación con los requerimientos de la sociedad y el contingente de personal preciso para su explotación; por lo que, en ausencia de todos estos datos y atribuida en principio al Gobierno por la Ley 17 de 1977 -art. 10 - la decisión sobre cuáles de los servicios mínimos precisos a garantizar en este caso de huelga son necesarios, los señalados no vulneran el derecho a la huelga, procediendo, consiguientemente, la estimación del presente recurso de apelación.

Considerando: Que por aplicación de lo dispuesto en el artículo 10.3 de la Ley de 26 de diciembre de 1978 sobre imposición de costas, procede imponer las del recurso en primera instancia a la parte demandante y sin expresa condena a ninguna de las causadas en la presente apelación.

\section{Comentario}

Véase comentario a la Sentencia de 11 de julio de 1980 (núm. 10 de 1980 de este Repertorio).

Núm. 13. Sentencia de 24 de septiembre de 1980. Contencioso-Administrativo. Sala III. Ponente, F. Roldán Martínez: ARTICULOS 28.2 Y 37.2 DE LA CONSTITUCION.

\section{Derecbo a la buelga: limites}

Servicios esenciales: limite a la medida de conflicto colectivo

El derecho a la huelga no es un derecho absoluto sino sometido a límites que deben interpretarse restrictivamente de acuerdo con el texto constitucional y Tratados internacionales suscritos en la materia por España.

En especial supone un límite al derecho a la huelga la garantía constitucional de que se asegure el mantenimiento de los servicios esenciales de la comunidad. El derecho a la huelga que es de directa aplicación necesita preceptos complementarios de desarrollo y aplicación concreta que lo encaucen sin que pueda reputarse que tal desarrollo niegue el derecho, sino que lo hace posible.

\section{Antecedentes:}

Véase Sentencia de 11 de julio de 1980 (núm. 10 de 1980 de este Repertorio) y Sentencia de 24 de septiembre de 1980 (número 12 de 1980 de este Repertorio).

CONSIDERANDo: Que habiendo sido interpuesto este proceso especial de protección de los derechos fundamentales de la Persona, reconocidos en nuestro texto constitucional, únicamente para impugnar las normas dictadas por el Ministerio de Transportes y Comunicaciones a la Dirección de la Compañía del Ferrocarril Me- 
tropolitano de Madrid y del Suburbano de Carabanchel-Plaza de España, transmitidas a su vez por la Dirección de la Compañía a sus empleados, en fecha 19 de marzo último estableciendo, en aplicación del Real Decreto 495/80 de 14 de marzo (R. 648), las medidas restrictivas a adoptar, conforme a lo establecido en el artículo $20^{\circ}$ del mismo, a fin de garantizar el mantenimiento o funcionamiento de ese servicio público, durante la huelga total y legal de veinticuatro horas anunciada para los días 13 y 20 del citado mes de marzo, resulta manifiesto, como así lo reconoce la sentencia apelada, que, al no haber sido impugnado dicho Real Decreto de $14 \mathrm{de}$ marzo, el ámbito del litigio queda limitado al examen de las normas de desarrollo del mismo o medidas de Servicio establecidas por el Ministerio; para decidir si constituyen o no restricción al derecho de huelga que el art. 28 de la Constitución (R. 1978, 2383), reconoce a los trabajadores para la defensa de sus intereses profesionales, para cuyo análisis debe partirse, de la legalidad y vigencia del referido Real Decreto de 14 de marzo último, como muy bien se razona en el Considerando segundo de la sentencia apelada, pero, teniendo presente que el párrafo $2 .^{\circ}$ del artículo 10 de la Ley $17 / 77$ de 4 de marzo (R. 490 y N. Dicc. 29184), que sirve de cobertura legal al Real Decreto de 14 de marzo último, expresamente habilita a la Administración (la autoridad Administrativa), para acordar «las medidas necesarias para asegurar el funcionamiento de los servicios de reconocida e inaplazable necesidad», dentro de los términos limitados que señalan los artículos 28.2 y 37.2 del texto constitucional; de otra parte, que como ya tuvo ocasión de pronunciarse esta Sala en anteriores sentencias - 11 julio y 24 septiembre (R. 2950 y 3248)- sobre esta materia de interpretación de los términos empleados en el texto constitucional en orden al aseguramiento de los servicios mínimos calificados de esenciales para la comunidad nacional, en los supuestos de huelga que establece, se tomaran las medidas «necesarias», para el mantenimiento del servicio público, no cabe estimar como conceptos diferentes los de «mantenimiento» y «funcionamiento» de los servicios esenciales, pues, tanto uno como el otro vocablo al estar referidos por el legislador para el aseguramiento del servicio esencial que resulte afectado por la situación de huelga, tienen significación análoga, pues, incluso el concepto «mantenimiento» de un servicio, que equivale a su puesta a punto, implica o comprende el «funcionamiento» de ciertos elementos materiales o técnicos del mismo para que se pueda prestar el servicio tan pronto termine la situación de huelga.

Considerando: Que siendo un servicio esencial el que presta el Metropolitano de Madrid, y disponiendo el artículo 2 del referido Real Decreto de 14 de mayo último, que, en cualquier situación de huelga, ha de asegurarse la prestación del mismo con carácter restrictivo, con el personal estrictamente necesario, para que el servicio del Metro se realice en condiciones de máxima seguridad, no cabe dudar que tanto este precepto como la norma habilitante del citado Real Decreto, o sea, el artículo 10.2 del Real Decreto-Ley $17 / 77$ atribuye a la Administración la facultad de precisar los servicios mínimos esenciales necesarios para garantizar el servicio del Metro en cada situación de huelga que se presente, y, aun siendo incuestionable que para fijar en cada caso las medidas restrictivas a adoptar deben ponderarse las circunstancias que concurran para, de adaptar las «medidas» a las «normas» a fin que la restricción al derecho de huelga sea mínima en cada supuesto que se dé, sin olvidar tampoco que, en todo caso, el servicio debe prestarse en condiciones de máxima seguridad para las personas usuarias, el personal de la Compañía y el mantenimiento del material de la misma, pero en el presente caso, no aparece que el Ministerio haya aludido o no haya tenido presente al dictar las normas impugnadas las circunstancias o hechos concurrentes a la situación de huelga total de veinticuatro horas anunciada en esta capital, sino que en atención a las distancias o largos desplazamientos existentes, desde muchos barrios de esta gran capital, para despla- 
zarse los trabajadores desde el domicilio hasta el lugar del puesto de trabajo así como los distintos horarios que existen de entrada y salida del personal, y la gran masa urbana y suburbana de trabajadores en Madrid, son circunstancias todas ellas bien notorias, que por serlo no necesitan de prueba, por lo que esta Sala no estima excesivas las ocho horas fijadas por el Ministerio para la prestación del Servicio (cuatro para el acceso y cuatro para el regreso del trabajo) por lo que siendo discrecional apreciación la fijación de ese tiempo fijado y ser dicho horario la razón básica por la que la Sala de instancia se pronunció por la estimación del recurso, apreciación que no es compartida por esta Sala, entiende debe estimar el presente recurso de apelación, ya que, por otra parte, no se ha justificado por los recurrentes que las normas impugnadas restrinjan el derecho a la huelga, por la concurrencia de cualquier otro hecho o circunstancia, en más que lo estrictamente necesario para posibilitar el derecho al trabajo en condiciones de máxima seguridad a la gran masa del resto de trabajadores de esta gran capital usuarios del Metropolitano que es notorio no puede ser absorbida por el transporte público de superficie.

\section{Comentario}

Véase comentario a la Sentencia de 11 de julio de 1980 (núm. 10 de 1980 de este Repertorio).

Núm. 14. Sentencia de 24 de septiembre de 1980. Contencioso-Administrativo. Sala V. Ponente, A. Falcón García: ARTICULOS 24, Y 117 DE LA CONSTITUCION.

\section{Tutela jurisdiccional}

Potestad jurisdiccional

Según la Sentencia, el artículo 24 de la Constitución es una declaración de derechos que no expresa la forma y medios de protección por los Tribunales, y la aplicación de lo dispuesto en el apartado $3 .^{\circ}$ del artículo 117 no es tampoco de directa aplicación, siendo preciso el previo desarrollo legislativo.

Carácter programático de los citados preceptos.

Considerando: Que en el presente recurso se impugna la clasificación efectuada al recurrente, coronel de Infantería de Marina, por los acuerdos del Consejo Superior de la Armada de 31 de mayo y 15 de septiembre de 1978, resoluciones en las que fue declarado «elegible» con el número seis entre los nueve coroneles clasificados; en sus alegaciones pretende que el párrafo segundo de la disposición adicional tercera de la Ley 68/78, que dispone que contra las resoluciones del Consejo Superior de la Armada no se dará recurso alguno, incluso el contenciosoadministrativo, con la única excepción de que se aleguen defectos de procedimiento, ba quedado derogada por el artículo 24 de la Constitución, y puede entrarse también a decidir sobre el fondo del asunto, o sea, sobre la calificación efectuada, y realizarse la precedente por el Tribunal; pero aparte de que tal disposición constitucional es una declaración de derechos y no expresa la forma y medios en que tales derecbos ban de ser protegidos por los Tribunales, el párrafo 3 del artículo 117 de la misma Constitución establece que «el ejercicio de la potestad jurisdiccional en todo tipo de procesos, juzgando y baciendo ejecutar lo juzgado, corresponde exclusivamente a los Juzgados y Tribunales determinados por las leyes, según las normas de competencia y procedimiento que las mismas establezcan», lo que lleva a que la extensión de la competencia ba de ser fijada por éstas, sin que baya quedado derogada ni la disposición citada ni el artículo 40 de la Ley de esta jurisdicción; pero además de lo expuesto, el suplico de la demanda pide se declare la 
nulidad de todo lo actuado en el expediente de clasificación del actor y su nueva clasificación como elegible, por la Administración, en el lugar que por justicia le corresponde, por lo que declarar sobre clasificación que le es debida, fallar sobre el fondo del asunto, sería una incongruencia, en relación con lo pedido en la demanda, infringiéndose el artículo 43 de la Ley jurisdiciconal.

\section{Comentario}

$\mathrm{Ni}$ lo dispuesto en el artículo 24 ni el apartado 3 del artículo 117 de la Constitución han derogado la disposición adicional tercera de la Ley 68/78, que dispone que contra las resoluciones del Consejo Superior de la Armada no se dará recurso alguno, incluso el administrativo, con la única excepción de que se aleguen defectos de procedimiento; tampoco el artículo 40 de la Ley de la Jurisdicción contencioso-administrativa.

Esta conclusión no hace sino reflejar la necesidad de que el principio constitucional de tutela efectiva de los jueces y Tribunales (art. 24) y la concepción expansiva de la jurisdicción ordinaria por relación a la militar (párrafos 3 y 5 del artículo 117) obtengan pronto desarrollo. A nuestro juicio, la comprensión de los citados principios constitucionales es incompatible con la inexistencia de recursos judiciales frente a la actividad administrativa, por lo que es certero el juicio del recurrente en el sentido de que la citada disposición adicional tercera de la Ley 68/78 puede entenderse derogada, así como el también citado artículo 40 de la Ley de la Jurisdicción contencioso-administrativa.

Núm. 15. Auto de 26 de septiembre de 1980. Contencioso-Administrativo. Sala III. Ponente, M. Sainz Arenas: ARTICULO 9.3 DE LA CONS. TITUCION.

\section{Principio de seguridad jurídica}

Mera cita en el Considerando cuarto del Auto de 26 de septiembre de 1980 del principio de seguridad jurídica consagrado en el artículo 9.3 de la Constitución.

Considerando: Que no puede prosperar el primer motivo del recurso, que se pretende fundar sobre la errónea afirmación que atribuye al auto apelado haber confirmado el acuerdo del Tribunal Económico Administrativo Central, creando con ello la confușión de si lo que ha decidido dicho auto es el fondo del asunto o bien una cuestión incidental; toda vez que el considerando único del auto recurrido se contrae a la pretensión de suspensión del acto administrativo combatido, esto es, a la formulada, al amparo del artículo 123 de la Ley de la Jurisdicción, mediante otrosí en el escrito de interposición del recurso contencioso-administrativo, y juzga procedente desestimarla por entender insuficiente la simple alegación de falta de liquidez de la entidad accionante, e igualmente, la parte dispositiva se limita a denegar la suspensión de la ejecución del acto impugnado, sin siquiera mencionar el acuerdo del Tribunal Económico Administrativo Central constitutivo de la cuestión de fondo, dejando así su confirmación o revocación a lo que se decida en la sentencia que se dicte en los autos principales de los que deriva la correspondiente pieza separada abierta conforme al párrafo primero del citado artículo 123 , ahora unida a estos autos de segunda instancia.

Constoerando: Que tampoco es atendible cuanto se alega sobre la naturaleza de la Renta de Aduanas, para concluir estableciendo distingos entre este y los demás impuestos que resultan contradictorios con las disposiciones del Decreto 511/1977, de 12 de febrero, cuyo vigor reconoce la parte apelante, que declaran aplicables las normas de la Ley General Tributaria y del Reglamento de Procedimiento para las reclamaciones económico-administrativas respecto de los derechos arancelarios a la importación y del impuesto de compensación de gravámenes interiores. 
Considerando: Que no es admisible tampoco el intento de relacionar el cumplimiento de las obligaciones fiscales con la conservación de las mercancías importadas en el patrimonio del sujeto pasivo o de cualquier otro responsable del tributo, ni que a ello haya de estimarse supeditada la solvencia o liquidez del deudor $\mathrm{ni}$, en general, las aducidas trabas crediticias bancarias, que, de aceptarse con el criterio del recurso, impondrían, en todo caso, la necesidad de acceder a las pretensiones de suspensión sin examinar las especiales circunstancias concurrentes en cada supuesto, que son, por el contrario, las que han de merecer preferente atención al tomar la decisión más adecuada; y puesto que ninguna aportación trae la apelación eficaz para subsanar la insuficiencia de la simple alegación que motivó la denegación pronunciada en la primera instancia (ya que la cuestión relativa a si el Decreto $2062 / 1974$ infringe o no lo dispuesto en la Ley General Tributaria no puede ser examinada en la pieza separada de suspensión, por constituir la de fondo del recurso contencioso-administrativo), no existe razón para revocar lo así resuelto por el auto apelado.

CONSIDERANDo: Que tampoco la pretensión que la apelación propugna adquiere solidez alguna con las citas, que a su favor se hacen, del artículo 9.3 de la Constitución española y de la Ley 62/1978, de 26 de diciembre, porque el principio de seguridad jurídica que el precepto constitucional garantiza no resulta afectado, sino, por el contrario, salvaguardado, por el juego de las acciones y recursos ejercitados ante las autoridades administrativas $y$ judiciales competentes, sustanciados conforme a sus especificas normas $y$. resueltos ponderando los derechos e intereses de las distintas partes -en este caso, también los del Tesoro Público-; y de otra parte, si bien es cierto que el artículo 7.0 de la precitada Ley de Protección de los Derechos Fundamentales de la Persona invierte los términos del 123 de la de lo ContenciosoAdministrativo, no deroga ni sustituye a éste ni, por tanto, puede aplicarse cuando, como ocurre en este caso y la apelación admite expresamente, el supuesto que se plantea en el presente recurso no se halla incluido en dicha Ley.

Considerando: Que, en definitiva, no se está en un caso de ejercicio de una facultad discrecional falto de motivación, como también se afirma en el recurso, sino en el de la denegación de una pretensión de suspensión del acto administrativo recurrido por falta de la indispensable justificación de que su ejecución haya de ocasionar los daños o perjuicios de reparación imposible o difícil, determinantes de la procedencia de otorgar la suspensión por imperativo del artículo 122 de la Ley de lo Contencioso-Administrativo, por lo que procede desestimar la apelación, sin que, según el artículo 131 de la misma Ley jurisdiccional, resulte necesario un pronunciamiento especial sobre las costas procesales causadas en la segunda instancia.

Núm. 16. Auto de 26 de septiembre de 1980. Criminal. Ponente, M. García Miguel: ARTICULOS 16.1, 16.3, 22, 24, 27.6, 27.7, 27.8, 28.1, 34, 107.5 DE LA CONSTITUCION.

Principio de unidad jurisdiccional

Jurisdicción militar: carácter excepcional y restringido

El principio de unidad jurisdiccional conlleva la expansión de la jurisdicción ordinaria y el constreñimiento de las jurisdicciones especiales y excepcionales a los específicos supuestos legales en los que les venga atribuida expresamente la competencia.

La protección jurisdiccional a que se refiere el artículo 24 en relación a la sección $1 .^{\text {a }}$, capítulo II, título I, y al artículo 53.2 se extiende a las personas físicas y jurídicas.

La jurisdicción ordinaria es la competente para conocer los delitos contra el honor de 
la Guardia Civil a tenor de lo dispuesto por la Constitución en su artículo 117.5 y la Ley de Protección jurisdiccional de 26 de diciembre de 1978.

\section{Antecedentes:}

Auto de 2 de mayo de 1980, núm. 4 de este Repertorio.

Considerando: Que la presente cuestión de competencia suscitada entre la Capitanía General de la 6. ${ }^{\text {a }}$ Región Militar y la Audiencia de San Sebastián plantea como único tema a resolver el relativo a cuál sea la jurisdicción competente para conocer de los delitos de injuria al Cuerpo de la Guardia Civil, o sea, si compete conocer a la jurisdicción militar o a la ordinaria, y el problema ya ha sido resuelto por esta Sala por auto de 2 de mayo del corriente año, en el sentido de que la competencia para conocer de los delitos de injurias cometidos contra dicho Benemérito Instituto corresponde a la jurisdicción ordinaria, por las razones ampliamente expuestas en dicha resolución, y que sintéticamente son las siguientes: La Ley de 26 de diciembre de 1978 sobre Protección Jurisdiccional de los Derechos Fundamentales de la Persona, en su artículo 1.2, se refiere a los derechos de reunión, expresión y asociación, a los de libertad personal, inviolabilidad de domicilio y correspondencia y a otros, estableciendo en su artículo 2 que los delitos y faltas cometidos contra los derechos fundamentales de la persona comprendidos en el ámbito de esta Ley serán juzgados por los jueces y tribunales de la jurisdicción ordinaria, de suerte que, como el Decreto de 20 de febrero de 1979, en su artículo 1 , incorporó al texto de la disposición anteriormente citada, entre otros, el derecho al honor, atribuyéndole la misma protección jurisdiccional, no cabe duda que la competencia corresponde, en principio, a la jurisdicción ordinaria, quedando como única cuestión a resolver la relativa a la determinación de si el honor al que se refiere la norma que se viene comentando es el individual, correspondiente a las personas físicas, o si debe comprenderse también el de las personas jurídicas, cuerpos, instituciones, clases del Estado u organismos públicos o privados, lo que debe resolverse en el sentido de que todos los referidos supuestos deben entenderse comprendidos en el precepto dado, que en el Título I de la Constitución se denomina «De los derechos y deberes fundamentales», sin que en él se distinga entre personas físicas y jurídicas y en la sección $1 .^{a}$ del capitulo II de dicho Título, artículo 24, se anuncia la protección jurisdiccional de tales derechos principio programático constitucional que se desarrolla por la Ley y Decretos anteriormente mencionados, robusteciendo esta tesis de que no son unicamente los derechos individuales los proclamados tutelados, sino todos los demás, lo que se dispone en los artículos 16.1, 16.3, 22, 27.6, 7 y 8, artículo 28.1 y artículo 34 de la Constitución.

Considerando: Que por todo ello, y además tenidos en cuenta el principio general del carácter atrayente de la jurisdicción ordinaria, proclamado en el artículo 10 y siguientes de la Ley de Enjuiciamiento Criminal y el principio fundamental y de rango superior de la unidad jurisdiccional proclamado en el numero 5 del articulo 117 de la Constitución, que conlleva la expansión de la jurisdicción ordinaria y el constreñimiento de las jurisdicciones especiales $y$ excepcionales a los específicos supuestos legales en los que les venga atribuida expresamente la competencia, procede decidir la presente cuestión de competencia a favor de la Audiencia Provincial de San Sebastián.

\section{Comentario}

El Tribunal Supremo sostiene en esta como en otras sentencias una línea doctrinal irreprochable, afirmando que el principio de unidad jurisdiccional conlleva la expansión de 
la jurisdicción ordinaria y constreñimiento del ámbito de las jurisdicciones especiales y excepcionales. La mención a jurisdicciones «especiales y excepcionales», sin embargo, no debe hacer suponer que se reconoce su existencia, salvo en el caso de la jurisdicción militar consagrada expresamente en el apartado $5 .^{\circ}$ del artículo 117 . El principio de unidad jurisdiccional, conforme al precepto anteriormente citado, sólo tiene su excepción en la jurisdicción militar, que sólo entra en juego con carácter residual «en el ámbito estrictamente castrense» y en los supuestos de estado de sitio, de acuerdo con los principios de la Constitución, lo que significa que no puede considerarse como una jurisdicción excepcional, al margen del conjunto de principios procesales que la Constitución consagra.

Conviene destacar que, sin embargo, no se ha utilizado exclusivamente el principio de unidad jurisdiccional del que se deriva el carácter atrayente de la jurisdicción ordinaria, sino que la competencia de dicha jurisdicción se afirma como consecuencia de la interpretación que se hace de la Ley de Protección jurisdiccional de los Derechos Fundamentales de la Persona en relación con algunos preceptos de la sección 1.a, capítulo II, Título I del texto constitucional. Según esta interpretación, la tutela jurisdiccional que dispensa la Constitución ampara a personas físicas y jurídicas, como se deduce de una serie de preceptos que en el Considerando transcrito se refieren. Hasta aquí la interpretación resulta a nuestro juicio adecuada y se desprende directamente del texto constitucional. Pero a partir de estas observaciones se llega a equiparar personas jurídicas a «cuerpos», «instituciones», «clases del Estado», «organismos públicos o privados», y esta equiparación es más que dudosa, aunque la conclusión que se alcanza, a la que podría llegarse tan sólo a partir del principio de unidad jurisdiccional, es a nuestro juicio la adecuada.

\section{Núm. 17. Auto de 24 de septiembre de 1980. Criminal. Sala II. Ponente, B. Gil Sáez: ARTICULO 25.2 DE LA CONSTITUCION.}

Mera cita del artículo 25.2 de la Constitución, que el recurrente conecta con el artículo 61.4 del Código Penal. A nuestro juicio, la conexión no es adecuada, habida cuenta de que el artículo 25.2 es un precepto que no va dirigido expresamente al juez, sino al legislador, que debe regular penas privativas de libertad orientadas bacia la reeducación y reinserción social. Esta expresión no supone habilitación alguna en los jueces para que puedan modificar la pena aplicable al margen de lo dispuesto en el Código Penal.

Considerando 2.0: Que el cuarto de los motivos del propio recurso, acogido al mismo cauce procesal que el precedente, reputando en su fondo y realidad la misma infracción de la regla $4 .^{\mathrm{a}}$ del artículo 61 , en relación con el artículo 25.2 de la Constitución y con los artículos 84, 92 y 93 del Código Penal, puesto que al imponer la pena superior a un año de prisión imposibilitaba la aplicación de la remisión condicional, no obstante la edad del procesado, su carencia de antecedentes penales, la inmadurez de su personalidad y la perfecta y correcta integración familiar con otros seis hermanos, cuyo conjunto de circunstancias desaconsejaban el internamiento penitenciario para cumplir una tan corta pena privativa de libertad, datos no tenidos en cuenta tampoco al ejercer el arbitrio otorgado por la repetida regla, alegación puramente subjetiva que incurre en inviabilidad por idénticas causas a las anteriormente señaladas en atención a lo facultativo de la disposición aplicada, que tiende a la individualización judicial de la punición del delito calificado, sin que pueda significar infracción de ley, à efectos de la censura casacional, la decisión lógica que precisamente se aplica en graduación racional y privada por el Tribunal de instancia que señala la extensión y límite cuantitativo de la penalidad, teniendo conocimiento personal, directo e insustituible de los elementos criminológicos y objetivos que la sirven de módulo en su decisión, bajo el límite único e incensurable de su apreciación en conciencia, que escapa a la revisión y codificación del recurso extraordinario formulado, como tan reiteradamente se tiene declarado y afirmado por esta Sala, incurriendo el motivo y alegación sustentadora en la ya indicada causa $1 .^{2}$ de inadmisión del artículo 884 de referencia. 
Núm. 18. Sentencia de 29 de septiembre de 1980. Criminal. Sala II. Ponente, A. Huerta y Alvarez de Lara: ARTICULO 20 DE LA CONSTITUCION.

\section{Libertad de expresión: limites}

La libertad de expresar y difundir libremente los pensamientos, ideas y opiniones mediante la palabra, el escrito o cualquier otro medio de reproducción no tiene en su ejercicio más limitaciones que las establecidas en el apartado $4 .^{\circ}$ del artículo 20 de la Constitución.

Considerando: Que el delito de desacato del artículo 240 del Código Penal precisa coordinarse, como viene declarando esta Sala, con el de injurias, calumnia o amenazas, que disyuntivamente completan su tipicidad y le sirven de base; tipicidad que claramente aparece de la declaración de hechos probados de la sentencia recurrida, que, recogiendo párrafos o expresiones proferidas en el escrito dirigido por el procesado al señor Magistrado de Trabajo de Palencia, con referencia a un asunto en el que había recaído sentencia desfavorable para la empresa de la que era consejero-delegado, ponen de manifiesto la injuria, porque nada puede empañar más el prestigio de los funcionarios encargados de administrar justicia que poner en duda que ésta ha sido el norte y guía de sus resoluciones, que tacha directa y repetidamente de injustas en su escrito $y$, no obstante ello, le anuncia que no recurrirá contra la sentencia - cuando es el único remedio procesal para combatir la sentencia injusta y conseguir que se dicte otra más ajustada y conforme a Derecho-, pero sí que montará una campaña de descrédito contra el magistrado, dando cuenta en Madrid, a las autoridades que considere, de esa sentencia, que él estima injusta y con la cual se aquietó; pero es que no sólo tacha de injusta la sentencia, lo cual, en términos de defensa, es el motivo usual que en la práctica del foro se viene alegando con todo respeto por los litigantes para fundamentar sus recursos contra ellas, sin que ello constituya delito alguno ni ofenda a los juzgadores al alegarse en términos procesales de defensa, sino que directa y personalmente, y eso sí es ya constitutivo de delito de desacato, se imputa al magistrado -empañando su prestigio- que no obró con justicia; imputación grave y ánimo de injuriar que aparece con mayor evidencia de la lectura íntegra del citado escrito dirigido al magistrado de Trabajo que de los párrafos aislados que se recogen en el factum, según ha podido apreciar esta Sala con la compulsa de los autos realizada al amparo del artículo 899 de la Ley de Enjuiciamiento Criminal ante las alegaciones hechas por el recurrente en sentido contratio en su escrito de formalización del recurso, por lo que, concurriendo los elementos objetivo y subjetivo que configuran el delito de desacato, procede desestimar el primer motivo del recurso, en el que, al amparo del número 1 del artículo 849 de la citada Ley de Enjuiciamiento Criminal, se denuncia la infracción por aplicación indebida del artículo 240 del Código Penal.

Considerando: Que se proclama y protege en el artículo 20 de la Constitución española de 1978 el derecho que tienen los españoles a expresar y difundir libremente los pensamientos, ideas y opiniones mediante la palabra, el escrito o cualquier otro medio de reproducción, sin otras limitaciones en el ejercicio de ese derecbo fundamental de la persona que las establecidas en el inciso $4 .^{\circ}$ del mismo precepto, entre las cuales, indudablemente, no se encuentran - como se alega por el recurrente- la de privar a un justiciable expresar libremente su opinión sobre la resolución que resuelve la cuestión que sometió a la decisión judicial, pero sí se encuentra entre esas limitaciones o restricciones a la libertad de palabra las establecidas por la Ley en protección del individuo, autoridades y sus agentes contra la calumnia, la injuria y la difamación, debiendo responder su autor, en cada caso, del abuso de esa libertad en los casos determinados en las leyes penales, y abuso de esa libertad lo constituye verter en escrito dirigido al magistrado conceptos gravemente in- 
juriosos para su persona, lo cual constituye un hecho punible típico, como se dice en el precedente Considerando de esta sentencia, por lo cual precede desestimar también el motivo segundo del recurso.

\section{Comentario}

La sentencia estima que entre las limitaciones que tiene la libertad de expresión no se encuentra la interdicción de que el justiciable opine sobre la resolución que resuelve la cuestión que sometió a la decisión judicial; pero, sin embargo, es un abuso punible de la libertad de expresión verter por escrito a un magistrado conceptos gravemente injuriosos para su persona. A nuestro juicio, la conclusión es irreprochable.

Núm. 19. Sentencia de 30 de septiembre de 1980. Contencioso-Administrativo. Sala III. Ponente, J. L. Ruiz Sánchez: ARTICULO 20.1 a) DE LA CONSTITUCION.

\section{Libertad de expresion}

Mera cita de la libettad de expresión.

\section{Antecedentes:}

La doctrina de esta Sentencia coincide con la de las Sentencias de 14 de agosto de 1979 (Repertorio 1979, núm. 8) y 4 de febreto de 1980 (Repertorio 1980, núm. 1).

Considerando: Que es necesario tener presente en esta apelación, interpuesta por la representación legal de don Alfonso Feliú Corcuera y otros, un doble condicionamiento en orden al ámbito y alcance del recurso suscitado, derivado uno del carácter especial y extraordinario que, por razón de la materia objeto de debate, establece el procedimiento peculiar objeto de regulación en la Ley 62/1978, de 26 de diciembre, y otro como específica conclusión de la naturaleza misma de la apelación en cuanto a la aplicabilidad de los principios rectores de la misma, contenidos sustancialmente en la Ley de Enjuiciamiento Civil, en virtud del juego de los reenvíos que a la misma se hace a través de la Ley Reguladora de esta jurisdicción, a la que, como supletoria, remite la propia Ley $62 / 1978$, lo cual nos obliga a eliminar aquellas objeciones $\mathrm{u}$ óbices que, articuladas por las partes oponentes al contencioso promovido, y desestimadas por la sentencia, no son susceptibles de reproducción, dada la conducta procesal adoptada por las mismas, circunstancia que se acentúa, respecto del apelante, en razón a las especiales características formales de la apelación reflejadas en la propia Ley 62/1978.

Considerando: Que, expuesto lo anterior, y, por tanto, excluida la cuestión de la inviabilidad del recurso, no podemos olvidar, al examinar la problemática de fondo suscitada, la peculiar naturaleza del procedimiento establecido por la referida Ley 62/1978, excepcional, sumario y urgente, que impide se extienda o afecte a otras cuestiones que no se refieran a la comprobación de si un acto del poder público modifica, restringe, priva o no el ejercicio de un derecbo fundamental de la persona -en el supuesto concreto de autos, la libertad de expresión- dentro del cauce o marco general de la actuación legal de dicho poder, y la valoración de estas circunstancias son las que deben ser racional y jurídicamente apreciadas para deducir si se ha producido o no esa consecuencia, como presupuesto necesario y previo que motiva la admisibilidad y subsiguiente viabilidad ad initio del proceso para discernir sobre la realidad y repercusión que puede haberse producido en el 
derecho fundamental denunciado como quebrantado, y en la sentencia apelada se analiza, con un criterio de exacta ponderación, la razón motivadora de la suspensión definitiva de los periódicos afectados, basada en una circunstancia meramente económica, exponiendo cómo esa supresión no afecta, en su íntima esencia, a la libertad de expresión, con análisis de la imposibilidad de poner a disposición de los que se conceptúen como afectados en ese derecho un medio que implica grave quebranto económico para la sociedad, constituyendo como única causa directa e inmediata de la suspensión definitiva de los periódicos afectados la indicada de las dificultades financieras, que se cifran en un monto de 90.405 .869 pesetas para ambos periódicos - La Voz de España, con un déficit en el ejercicio de 1979 de 36.795 .035 pesetas, y Unidad, por 53.610.334 pesetas en el mismo período-, y este hecho, como generador del acuerdo impugnado, es reconocido paladinamente por los recurrentes, en unión del Real Decreto 1434/1979, de 16 de junio, como específicas motivaciones del mismo, si bien niega efectividad y verosimilitud a la nefasta situación económica de los periódicos y, por otro lado, trata de razonar los vicios de nulidad que estima adolece el referido Real Decreto.

Considerando: Que al combatirse en apelación la sentencia recurrida, de acuerdo con el procedimiento establecido por la Ley 62/1978, se acusa de incongruencia a la misma, en cuanto se dice no ha examinado la totalidad de los problemas planteados, circunstancia que no es admisible, porque no sólo son objeto de razonamiento, sino que se inspira haciendo referencia a la que se dictó por este Tribunal con fecha 14 de agosto de 1979, y la extraordinaria de revisión de 4 de febrero de 1980 , con la circunstancia de que ni se ataca el Real Decreto $1434 / 1979$, poniendo de relieve hipotéticos vicios que se acusan provocan su nulidad, ni se postula tal pretensión, ni se ha encauzado en el orden jurisdiccional la posibilidad de su conocimiento, ello hace que resalte con mayor nitidez la interrelación entre la pretensión deducida a través del procedimiento excepcional y la ansiada restauración profesional de los recurrentes, en un puesto o actividad de trabajo, que en su manifestación genuina no quebranta el derecho a la libertad de expresión o de libre difusión de ideas, pues se trata del cierre de unas empresas periodísticas que tienen graves dificultades financieras, que hasta entonces han sido empleadas por los recurrentes para la expresión de sus pensamientos e ideas en función a la actividad laboral desempeñada en los mismos, pero sin que el hecho de la suspensión de esas empresas haya menoscabado sus libertades de expresión, aunque sí privado del medio empleado en virtud de la relación laboral - que se resuelve de acuerdo con el Real Decreto $1434 / 1979$, cuya reapertura provocaría un gravísimo perjuicio no sólo en el aspecto económico o material, sino incluso respecto de los otros empleados y trabajadores no recurrentes, a lo que es preciso adicionar la limitada accionabilidad en función de la excepcionalidad del procedimiento en razón a la materia, que permite la posibilidad de actuación del artículo $10^{\circ}$ de la Ley Reguladora de esta jurisdicción, así como derivación del condicionamiento que la Ley 62/1978 establece en orden a interposición de la apelación y alegaciones que deben ser objeto de consideración valorativa por el Tribunal ad quem.

Núm. 20. Sentencia de 3 de octubre de 1980. Contencioso-Administrativo. Sala III. Ponente, J. Rodríguez Hermida: ARTICULOS 7, 9, 14 Y 21 DE LA CONSTITUCION.

\section{Libertad sindical}

Los referidos artículos de la Constitución se hacen constar como vistos sin que se refieran en el contenido de los considerandos de la sentencia. Se confirma la sentencia apelada 
por el abogado del Estado, cuyo fallo se contiene en el segundo resultando de la sentencia que transcribimos.

Considerando: Que al tener la materia objeto de la presente apelación una legislación sui generis y específica, a ella ha de atenerse esta Sala, quedando la Ley jurisdiccional como supletoria de aquélla, artículo 6 de la Ley de 26 de diciembre de 1978, por lo que al preceptuar el artículo 9 de la calendada Ley que la «apelación se preparará mediante escrito razonado ante la Sala sentenciadora», este Tribunal tiene que desestimar la apelación interpuesta por la Abogacía del Estado contra la sentencia que nos ocupa, toda vez que el escrito que sirvió de vehículo a la apelación examinada, de fecha 19 de mayo de 1980, se formuló sị el más leve atisbo al razonamiento o consideración alguna no sólo de hecho, sino, lo que es más trascendental, de derecho, lo que implica, sin más, la desestimación del mismo, pues tal razonamiento es trascendental, ya que al no haber alegaciones ante esta Sala, son los razonamientos y consideraciones vertidos en él los que ha de examinar la misma, al objeto de ver la adecuación o no a derecho de la sentencia contra la que se interpone, no debiendo olvidarse que éste también es el criterio que sigue esta Sala en los procesos regidos por el texto jurisdiccional de 1956, tanto si no se formulan alegaciones ante ella como si se pretende cumplir tal requisito bajo la fórmula de remitirse a los razonamientos y consideraciones legales vertidos en los respectivos escritos del proceso apelado, por todo lo cual debe desestimarse el recurso de apelación formulado por el abogado del Estado, precisamente por esta consideración y no porque debió ser inadmitido por la Sala a quo, puesto que si el escrito bajo el cual se prepara la correspondiente apelación está o no suficientemente razonado, es un presupuesto que nunca debe ser acogido bajo el prisma de la admisibilidad o inadmisibilidad del mismo, siendo materia del Tribunal ad quem y no de la Sala a quo su estimación o desestimación.

Considerando: Que, por lo que se refiere a la adhesión a la presente apelación, formulada por la representación del Sindicato Unitario (SU), y reconducida, exclusivamente, al apartado $3 .^{\circ}$ del Fallo de la Sentencia controvertida, no acogida por dicha resolución, la Sala tiene que desestimar dicha pretensión, pues para acceder a la concesión de locales postulada habría de cumplirse cierta preceptiva legal [art. 3., ap. c) del Real Decreto 19/1976], así como de los demás preceptos legales que pautan esta materia, preceptiva que no se ha cumplido, como lo denota el hecho de que, para legitimar la concesión de locales, el Sindicato apelante acude a las concesiones que en su día se hicieron a UGT, CCOO y USO, sin demostrar que las concesiones en cuestión se darían cumpliendo todos y cada uno de los requisitos que la preceptiva imperante en la materia exige; incluso, es más, dicho Sindicato alude a las citadas concesiones y a su otorgante discrecional, sacando de ellas un precedente administrativo para viabilizar la concesión por él instado, puesto que, según razona, si así no se hiciera, se conculcaría el principio de igualdad ante la Ley, razonamiento y consecuencias carentes de valor, pues del simple otorgamiento de concesiones discrecional y sin ajustarse a la preceptiva legal imperante no se puede sacar un precedente válido y vinculante, ya que si anteriormente la Administración obró mal, no por tal instrucción se puede seguir sine die obrando a espaldas de la Ley, en cuanto que las precedentes ilegales no pueden vincular a los Tribunales.

Considerando: Que, en cuanto a costas, no hay motivos suficientes para su imposición expresa a ninguna de las partes litigantes. 


\section{Comentario}

El contenido del fallo de la Sentencia de 2 de abtil de 1980 es irteprochable en su correcta aplicación del principio de libertad sindical en relación con el de no discriminación.

\section{Nủm. 21. Sentencia de 6 de octubre de 1980. Contencioso-Administrativo. Sala IV. Ponente, E. Medina Balmaseda: ARTICULO 14 DE LA CONS- TITUCION.}

Mera cita de los principios de seguridad jurídica y de igualdad, para reforzar una conclusión que se deduce directamente de la Ley del Suelo en sus artículos 32 y 39.

ConsIDERANDO: Que por los propios fundamentos de la sentencia apelada en invocación de los artículos 32 y 39 de la Ley del Suelo, en su texto de 12 de mayo de 1956, dada la fecha de los acuerdos municipales impugnados y la modificación de rasantes sin el cumplimiento de los requisitos exigidos en los artículos invocados, así como el principio de seguridad jurídica y de igualdad de los españoles, consagrado éste boy ya en la Constitución de 27 de diciembre de 1978, en su artículo 14, hace que la pretensión de Promotora Rubí deba prosperar y acceder a ella, confirmando el fallo recurrido, si bien sin hacer expresa imposición de costas a la empresa apelante Crisan, S. A., cuyo recurso de apelación se desestima.

\section{Núm. 22. Auto de 9 de octubre de 1980. Criminal. Ponente, A. Huerta y Alvarez de Cara: ARTICULO 15 DE LA CONSTITUCION.}

\section{Pena de muerte: abolición}

Mera cita del artículo 15 de la Constitución, en el que queda abolida la pena de muerte. La sentencia plantea el problema de la formación del Tribunal de las Audiencias Provinciales y alcanza la conclusión de que, pese a la abolición de la pena de muerte, los Tribunales, cuando el fiscal y las demás partes acusadoras piden la pena de reclusión mayor, el Tribunal debe constituirse con cinco miembros, razón por la que el auto decreta la nulidad de todas las actuaciones a partir de las sesiones del juicio oral y ordena se constituya Tribunal con cinco magistrados.

Véase, sobre este tema, R. Caballero Bonald, Formación del Tribunal en las Audiencias Provinciales (articulo 145 de la Ley de Enjuiciamiento Criminal), en «Boletín de Información del Ministerio de Justicia», núm. 1229 de 5 de febrero de 1981.

Considerando: Que la sentencia recurrida, dictada por tres magistrados, condena al procesado, como autor responsable de dos delitos de robo con homicidio, con las agravantes de alevosía, desprecio de sexo y edad en uno de ellos y de alevosía, premeditación y desprecio de edad en el otro, a dos penas de reclusión mayor, una por cada delito, de acuerdo con la petición fiscal en sus conclusiones definitivas y las de las acusaciones particulares.

Considerando: Que el párrafo 2.0 del artículo 145 de la Ley de Enjuiciamiento Criminal establece que «para dictar autos y sentencias en las causas cuyo conocimiento corresponde a las Audiencias de lo Criminal o a la Sala de las respectivas Audiencias Territoriales serán necesarios tres magistrados, y cinco para dictar sentencia en las causas en que se hubiere pedido pena de muerte, cadena o reclusión perpetuas", abolidas estas penas por el Código Penal de 1932 y boy abolida nuevamente la pena de muerte por la Constitución de 1978, después de su restablecimiento en 1934, se estableció para sustituirla la todavía subsistente pena de reclusión mayor, con duración de veinte años y un día a treinta años, según se desprende de 
la propia exposición de motivos y se declara en sentencias de 21 de noviembre de 1969 y 27 de septiembre de 1973.

ConsiderANDo: Que esta Sala, resolviendo la cuestión procesal, tan debatida por la doctrina de si el Tribunal de Instancia ha de constituirse con tres o cinco magistrados cuando se pida por alguna de las partes la pena de reclusión mayor, ha declarado, en Sentencia de 5 de matzo de 1980, que el Tribunal de Instancia ha de formarse con cinco magistrados cuando la petición de pena sea la de treinta años de reclusión mayor, porque este límite es el que permite determinar la semejanza con la cadena o reclusión perpetua y considerar la reclusión mayor como sucedánea de éstas.

ConsIDERANDo: Que, habiéndose constituido el Tribunal de Instancia con tres magistrados, no obstante ser la petición fiscal y de las demás partes acusadoras de treinta años de reclusión mayor, se incumplió el mandato del párrafo $2 .^{\circ}$ del citado artículo 145 de la Ley de Enjuiciamiento Criminal, que determina serán necesarios cinco magistrados para dictar sentencia en estas causas, proceda, dado que los preceptos procesales son de orden público, declarar de oficio la nulidad del juicio oral, en virtud de lo dispuesto en el número 3 del artículo $60^{\circ}$ del Código Civil, que establece la nulidad de pleno derecho de los actos contrarios a las normas imperativas y las prohibitivas, salvo que en ellas se establezca un efecto distinto para el caso de contravención.

Se decreta la nulidad de todas las actuaciones practicadas por la Sección 3.a de la Audiencia Provincial de Barcelona en la causa número 111, rollo número 3.379 de 1978, procedente del Juzgado de Instrucción de Barcelona, número 14, por robo con homicidio, contra Esteban Romero Sánchez, a partir de las sesiones del juicio oral. Devuélvanse a tal efecto los autos a dicho Tribunal para que, constituido con cinco magistrados, y previa citación de las partes, testigos y demás personas que proceda, se celebre de nuevo el juicio oral dictado en su día la sentencia procedente en Derecho y se declaran de oficio las costas de este recurso.

\section{Núm. 23. Sentencia de 13 de octubre de 1980. Contencioso-Administrativo. Sala III. Ponente, J. L. Ruiz Sánchez: ARTICULO 103.1 DE LA CONSTITUCION.}

Mera cita del artículo 103.1 de la Constitución, con relación al 83.2 de la Ley reguladora de la Jurisdicción Contencioso-administrativa, que el recurrente invoca para fundamentar un supuesto caso de desviación de poder. La sentencia desestima el recurso.

Considerando: Que como derivación de lo consignado y de la conjugación de los preceptos atinentes - art. 27 de la Ley de Puertos y 42 a 54 del Reglamento-, claramente se infiere la diferencia concurrente entre un «proyecto de obras» y un «proyecto de zona de servicio», con tratamiento jurídico perfectamente diferenciado, dando lugar con ello, y reconocida la aportación de los documentos esenciales, a la conclusión establecida en la sentencia apelada en orden a la observancia de los trámites correspondientes a la fase adecuada - art. 51 del Reglamento de Puertos-, con las secuelas derivadas no sólo de la inexistencia de nulidad, sino de anulabilidad, como se postula por la parte tecurrente, y menos aún puede sentarse una premisa sobre supuestos cargados de presunciones nugatorias, basadas en que carecería de efectividad la zona de servicio caso de no llevarse a cabo el desvío del río Llobregat o de no proyectarse definitivamente la dársena en el cauce del citado 
río, porque se tratan de «obras faraónicas» - según expresión de la parte apelante-, puesto que la consecuencia de su positivación se refleja en el procedimiento contencioso que finó con la sentencia de esta Sala de 13 de marzo de 1978, que hace quebrar el razonamiento por el que se pretende sumir la «aprobación de un proyecto de zona de servicio» en el régimen de los artículos 42 a 46 del Reglamento, esto es, como un «proyecto de obras», máxime cuando se reconoce de forma paladina que «no se pone en duda que el proyecto de ampliación de la zona de servicio contenga la documentación pertinente y haya sido aprobado por el organismo competente», circunstancias todas ellas que nos conducen a la conclusión de rechazar el último intento de impugnación, al invocar el «desvío de poder» al amparo de los artículos 83.2 de la Ley Reguladora de esta jurisdicción en relación con el 103.1 de la Constitución, puesto que, teniendo en cuenta la doctrina sentada por este Tribunal en orden a la concepción, presupuestos y efectividad del instituto que contemplamos, no puede sentarse la secuela objeto de previsión en el artículo 83.3 para apreciar su existencia, por lo que procede, con desestimación de la apelación interpuesta, la confirmación de la sentencia recurrida.

\section{Núm. 24. Auto de 14 de octubre de 1980. Criminal. Ponente, J. Moyna Menguez: ARTICULO 117.5 DE LA CONSTITUCION.}

\section{Principio de unidad jurisdiccional \\ Jurisdicción militar: carácter excepcional y restringido}

El principio de unidad jurisdiccional conlleva la expansión de la jurisdicción ordinaria y el constreñimiento de las jurisdicciones especiales y excepcionales a los específicos supuestos legales en los que les venga atribuida expresamente la competencia.

La protección jurisdiccional a que se refiere el artículo 24 en relación a la sección 1., capítulo II, título I, y al artículo 53.2, se extiende a las personas físicas y jurídicas.

$\mathrm{La}$ jurisdicción ordinaria es la competente para conocer los delitos contra el honor de la Guardia Civil a tenor de lo dispuesto por la Constitución en su artículo 117.5 y la Ley de Protección Jurisdiccional de 26 de diciembre de 1978.

\section{Antecedentes:}

Autos de 2 de mayo de 1980 y 26 de septiembre de 1980 (núms. 4 y 16 de este Repertorio).

Considerando: Que están comprendidos en el ámbito de aplicación de la Ley de Protección Jurisdiccional de los Derechos Fundamentales de la Persona, de 26 de diciembre de 1978, los derechos al honor, según resulta del artículo 1.0-2 de dicha Ley, y de su Disposición Final en relación con el Real Decreto legislativo de 20 de febrero siguiente, artículo único, y los delitos y faltas contra dicho derecho «serán enjuiciados por los Juzgados y Tribunales de la jurisdicción ordinaria, según su propia competencia (art. $2 .^{\circ}-1$ ), con derogación de cualesquiera disposiciones que se expongan a lo prevenido en esta Ley» (Disposición derogada, con la eficacia prevenida en el artículo $2 .^{\circ}-2$ del Código Civil).

Considerando: Que la Ley citada, en el artículo $4 .^{\circ}$-incisos 2 y 4 -, al referirse a la forma de persecución de estos delitos, hace una alusión particularizada a la calumnia o injuria por escrito y con publicidad o entendida oralmente ante un concurso de personas y, asimismo, a las ofensas dirigidas a la autoridad, corporaciones 
o clases determinadas del Éstado, debiendo entenderse -conforme declararon los autos de esta Sala de 2 de mayo y 26 de septiembre del año en curso- que los derechos fundamentales constitucionalmente protegidos, en este caso los derechos al honor, tienen por sujeto tanto a las personas físicas como a las personas jurídicas, y entre ellas los cuerpos, instituciones o clases determinadas del Estado, sin hacer excepción hacia las de carácter militar, porque la Ley no hace salvedad alguna y es regla interpretativa la cualidad atrayente o extensiva de la jurisdicción ordinaria, proclamada en el artículo 10 de la Ley de Enjuiciamiento Criminal y con primerísimo rango en el artículo 117.5 de la Constitución.

Considerando: Que la moción presentada por uno de los concejales del Ayuntamiento de Pamplona - que es el caso sometido a la decisión de esta Sala especialsobre la necesidad de que los mozos navarros hicieran el servicio militar en Euzkadi, por considerar «extranjero» al Ejército, bien porque constituya un epíteto afrentoso, bien por otras connotaciones penales que no es ocasión de señalar, debe ser sometido al conocimiento y resolución de los órganos de la jurisdicción ordinaria, en este caso de la Audiencia Provincial de Pamplona, de acuerdo con los fundamentos legales transcritos, que han sido aceptados por esta Sala en los autos de 2 de mayo y 26 de septiembre antes citados.

\section{Comentario}

Véase Auto de 26 de septiembre de 1980, número 16 de este Repertorio.

Núm. 25. Sentencia de 20 de octubre de 1980. Contencioso-Administrativo. Sala IV. Ponente, E. Díaz Eimil: ARTICULO 137 DE LA CONSTITUCION.

\section{Autonomía municipal}

La autonomía municipal en materia urbanística es hoy principio rector de la organización territorial del Estado, acogido y declarado en el artículo 137 de la Constitución.

Consmorando: Que en impugnación de la sentencia apelada, la Abogacía del Estado formula en su escrito de alegaciones un conjunto de razonamientos que resume en tres conclusiones, respectivamente consistentes, la primera, en que los alcaldes no pueden suspender las licencias concedidas por las Cómisiones Provinciales de Urbanismo en el ejercicio de las facultades subrogatorias que les concede el artículo 9.7 del Reglamento de Servicios de las Corporaciones Locales; la segunda, en no haberse cumplido el plazo de tres días que establece el artículo 118.1 de la Ley de esta jurisdicción, y la tercera, en que la licencia suspendida no incurre en infracción urbanística grave que sea «manifiesta».

Considerando: Que dichas tres conclusiones han sido ya rechazadas por la sentencia apelada con apoyo en una fundamentación jurídica, que esta Sala acepta íntegramente $\mathrm{y}$ en cuya confirmación debe aquí reiterarse, primero, que en el término «recursos» que emplea el artículo 220 del Texto Refundido de 9 de abril de 1976 debe entenderse comprendida toda acción dirigida a obtener la nulidad del acto administrativo, cualquiera que sea su titular, $y$, por tanto, no sólo aquellas que puedan corresponder a los administrados, sino también las que competen a la Administración respecto a los actos de otras Administraciones o de los suyos propios, y entre estas últimas todas las que le vienen atribuidas en defensa de la legalidad 
urbanística, incluida la de suspensión de los efectos de las licencias que concede a los alcaldes el artículo 186 del Texto Refundido citado, pues cualquiera otra interpretación conduciría a contradecir el propósito y voluntad del legislador de potenciar los instrumentos de control y restablecimiento del orden urbanístico, manifestados en la exposición de motivos de la Ley de Reforma de 2 de mayo de 1975, así como limitar sin fundamento normativo alguno la autonomia municipal en esta materia, convertida boy en esencial principio rector de la organización territorial del Estado, acogido y declarado en el artículo 137 de la Constitución, y en virtud de ello, así como del usual significado jurídico del comentado término de «recurso», procede aquí declarar que, en aplicación conjunta de los mencionados arts. 186 y 220, los alcaldes tienen facultad para suspender, por razones de manifiesta infracción urbanística grave, los efectos de las licencias que concedan las Comisiones Provinciales de Urbanismo al amparo del art. 9 del Reglamento de Servicios de las Corporaciones Locales; segundo, que el plazo de tres días que establece dicho art. 186, en concordancia con el 118 de la Ley de esta jurisdicción, se inició a partir del Decreto de la Alcaldía de 23 de junio de 1977, en virtud del cual se acordó la suspensión que dio origen a este proceso, pues el anterior Decreto, de 16 del mismo mes, no puede entenderse reproducido por aquél, dado que entre ellos existe la fundamental diferencia de que el primero acordó la suspensión de los efectos de la licencia de conformidad con lo previsto en el repetido artículo 186, mientras que en el segundo se ejercitó la acción de suspensión de obras que se realizan sin licencia, regulada en el artículo 184 del mismo Texto Refundido, acción ésta que es totalmente ajena a traslado alguno a la Sala de lo Contencioso-Administrativo y, por tanto, al indicado plazo de tres días, y por ello procede desestimar el motivo que en este aspecto formula la Abogacía del Estado, en relación a la cual es conveniente aclarar que, si bien parece contradictorio que a los pocos días de suspender unas obras por falta de licencia, se suspendan los efectos de la licencia que autoriza dichas obras, sin embargo, tal contradicción desaparece si se tiene en cuenta que la ejecución de la primera suspensión fue impedida por el gobernador civil, en una actuación que, siendo una verdadera «vía de hecho», se pretendió justificar en la existencia de la licencia concedida por la Comisión Provincial de Urbanismo, y tal circunstancia obligó al alcalde a dirigir su facultad suspensiva contra los efectos de esta licencia, en cumplimiento de su deber de insistir en la defensa de la legalidad urbanística, con el único medio jurídico que le quedaba, a consecuencia de dicha intervención gubernativa, y tercero, la licencia suspendida autorizó a construir sobre un terreno calificado de «zona verde» en el Plan General de Ordenación Urbana, y ello constituye infracción urbanística, calificada de grave por el artículo 226.2 del Texto Refundido, cuya condición de «manifiesta» no desaparece por el hecho de que el Plan Parcial contenga una zonificación distinta, pues siendo ésta una norma de desarrollo del Plan General, carece de efecto jurídico alguno en todo aquello en que lo contradiga o modifique con incumplimiento de lo ordenado por el párrafo $2 .^{\circ}$ del número 1 del artículo 13 del repetido Código Urbanístico, y, por tanto, también en este aspecto es correcta y acertada la sentencia apelada, al anular por tal motivo la licencia suspendida, la cual además incide en la nulidad de pleno derecho de la letra a), número 1 del artículo 47 de la Ley de Procedimiento Administrativo, en cuanto que fue concedida por la Comisión Provincial de Urbanismo, sin que se hubiera operado la subrogación del citado artículo 9 del Reglamento de Servicios, dado que la facultad de su concesión había sido ya agotada por la decisión denegatoria del Ayuntamiento, adoptada en tiempo hábil para ello, según se desprende del oficio de 7 de marzo de 1977, dirigido al mismo por la Delegación Provincial del Ministerio de la Vivienda, y de la cual tuvo conocimiento aquella Comisión antes de otorgar su licencia y, en consecuencia, con datos suficientes de su incompetencia para ello. 


\section{Comentario}

La alusión a la autonomía municipal le sirve de fundamento para sostener que el término «recursos» del artículo 220 del Texto Refundido de 9 de abril de 1976 comprende las facultades de la Administración para obtener la nulidad de actos administrativos y concretamente que los alcaldes tienen facultad para suspender, por razones de manifiesta infracción urbanística grave, los efectos de las licencias que conceden las Comisiones Provinciales de Urbanismo al amparo del artículo 9 del Reglamento de servicios de las Corporaciones locales.

Núm. 26. Sentencia de 21 de octubre de 1980. Contencioso-Administrativo. Sala III. Ponente, F. Roldán Martínez: ARTICULO 9.3 DE LA CONSTITUCION.

\section{Principio de legalidad}

\section{Principio de jerarquía normativa}

La interpretación de las normas sancionadoras debe hacerse siempre en el sentido más favorable al inculpado (principio pro reo). Los principios de legalidad y jerarquía normativa consagrados en el artículo 9.3 de la Constitución determinan que la falta de cobertura legal de hechos objeto de sanción hacen que no sean éstos determinantes de culpabilidad.

Considerando: Que siendo objeto de las resoluciones impugnadas en el presente recurso la imposición de la sanción de 400.000 pesetas a la entidad Cirte, S. A., titular del cinematógrafo «Novedades», de esta capital, por infracción de la «cuota de pantalla» durante los años 1976 y 1977, por un déficit en la proyección o exhibición de películas españolas, según resulta del expediente de sanción seguido a dicha empresa, en relación a los días que correspondan películas españolas por los de películas extranjeras proyectada, resulta manifiesto que la valoración y calificación de estos hechos se mueve en el ámbito de la facultad punitiva del Estado, cuyo ejercicio, sea cual sea la jurisdicción o campo en que se produzca, viene sujeto a unos mismos principios, dentro de los que puede citarse el de pro reo y tipicidad, es decir, que esté prevista en una norma jurídica anterior, antijurídica, esto es, lesiva de un bien jurídico protegido por el Ordenamiento vigente, por lo que si la norma sancionadora es anulada por una sentencia ejecutoria como lo han sido los artículos 17 y 19 del Decreto de 11 de noviembre de 1977, declarados ilegales por la sentencia ejecutoria de esta Sala, de fecha 9 de julio de 1979, por estar la cuota de pantalla regulada en un decreto sin rango de ley y ser esta sentencia reservada a ley formal, por representar una específica y grave limitación al principio de libertad de comercio para las empresas cinematográficas, declarándose por ello que tales preceptos, por su carácter reglamentario, contradecían el principio de legalidad y el de jerarquía normativa, proclamados y garantizados ambos en el texto constitucional -art. 9.3-, por lo que, al desaparecer la cobertura legal de los becbos que fueron objeto de sanción, determinantes de la responsabilidad administrativa, no se puede formular en el momento, acto de un enjuiciamiento, un reproche de responsabilidad contra la entidad recurrente, autora de los mismos, porque al baberse anulado la norma sancionadora, los preceptos que fueron anulados por aquella sentencia, es claro que los becbos producidos bajo sus efectos no son determinantes de culpabilidad, pues la interpretación de una norma sancionadora siempre debe hacerse en el sentido más favorable al inculpado y ajustándose a la realidad social del momento en que los hecbos se produjeron, en aplicación del principio «pro reo» que preside esta materia; de lo dispuesto en el artículo 4.2 del 
Título Preliminar del Código Civil, en cuanto al ámbito de aplicación en el tiempo de las leyes sancionadoras, y de lo establecido en orden a los efectos de las nulidades de pleno derecho, como fue la declarada por aquella sentencia, por lo que al haber sido declarada por la sentencia de esta Sala de 9 de junio de 1979 la ilegalidad de la llamada «cuota de pantalla», no procede aplicar las disposiciones sancionadoras de aquel Decreto, que precisamente fueron las declaradas nulas, siendo asimismo improcedente. aplicar la nueva Ley de 10 de enero de 1980 y Real Decreto de 11 de julio de 1980 sobre protección del cine por no tener efectos retroactivos sus preceptos sancionadores, por aplicación de lo que ya se deja sancionado y lo dispuesto en el artículo 4.2 del Título Preliminar del Código Civil.

\section{Comentario}

La utilización de los principios de legalidad y jerarquía normativa son irreprochables y determinan la estimación del recurso interpuesto contra acuerdos del Consejo de Ministros, que anula, ordenando la devolución de las cantidades ingresadas en concepto de depósito por la sanción impuesta.

Núm. 27. Sentencia de 24 de octubre de 1980. Contencioso-Administrativo. Sala III. Ponente, F. Roldán Martínez: ARTICULOS 28.2 Y 37.2 DE LA CONSTITUCION.

Derecbo de buelga: limites

Servicios esenciales: límite a la medida de conflicto colectivo

El derecho a la huelga no es un derecho absoluto, sino sometido a límites que deben interpretarse restrictivamente de acuerdo con el texto constitucional y tratados internacionales suscritos en la materia por España.

En especial supone un límite al derecho a la huelga la garantía constitucional de que se asegure el mantenimiento de los servicios esenciales de la comunidad. El derecho a la huelga, que es de directa aplicación, necesita preceptos complementarios de desarrollo y aplicación concreta que lo encaucen, sin que pueda reputarse que tal desarrollo niegue el derecho, sino que lo hace posible.

\section{Antecedentes:}

Véase Sentencia de 11 de julio de 1980 (núm. 10 de 1980 de este Repertorio); Sentencia de 24 de septiembre de 1980 (núm. 12 de 1980 de este Repertorio), y Sentencia de 24 de septiembre de 1980 (núm. 14 de 1980 de este Repertorio).

Considerando: Que babiendo sido interpuesto este proceso especial de protección de los derecbos fundamentales de la persona, reconocidos en nuestro texto constitucional, únicamente para impugnar las normas dictadas por el Ministerio de Transportes y Comunicaciones a la Dirección de la Compañía del Ferrocarril Metropolitano de Madrid y del Suburbano de Carabanchel-Plaza de España, transmitidas a su vez por la Dirección de la Compañía a sus empleados, en fecha 19 de marzo último, estableciendo, en aplicación del Real Decreto 495/1980, de 14 de marzo, las medidas restrictivas a adoptar, conforme a lo establecido en el artículo $20^{\circ}$ del mismo, a fin de garantizar el mantenimiento o funcionamiento de ese servicio público, durante la huelga total y legal de veinticuatro horas, anunciada para los días 13 y 20 del citado mes de marzo, resulta manifiesto, como 
así lo reconoce la sentencia apelada, que, al no haber sido impugnado dicho Real Decreto de 14 de marzo, el ámbito del litigio queda limitado al examen de las normas de desarrollo del mismo o medidas de servicio establecidas por el Ministerio, para decidir si constituyen o no restricción al derecbo de buelga que el artículo 28 de la Constitución reconoce a los trabajadores para la defensa de sus intereses profesionales, para cuyo análisis debe partirse de la legalidad y vigencia del referido Real Decreto de 14 de marzo último, como muy bien se razona en el Considerando segundo de la sentencia apelada, pero teniendo presente que el párrafo $2 .^{\circ}$ del artículo 10 de la Ley 17/1977, de 4 de marzo, que sirve de cobertura legal al Real Decreto de 14 de marzo último, expresamente babilita a la Administración (la autoridad administrativa) para acordar «las medidas necesarias para asegurar el funcionamiento de los servicios de reconocida e inaplazable necesidad», dentro de los términos limitados que señalan los artículos 28.2 y 37.2 del texto constitucional; de otra parte, que, como ya tuvo ocasión de pronunciarse esta Sala en anteriores sentencias (11 de julio y 24 de septiembre) sobre esta materia de interpretación de los términos empleados en el texto constitucional en orden al aseguramiento de los servicios minimos calificados de esenciales para la comunidad nacional, en los supuestos de buelga que establece, se tomarán las medidas «necesarias» para el mantenimiento del servicio público, no cabe estimar como conceptos diferentes los de «mantenimiento» $y$ «funcionamiento» de los servicios esenciales, pues tanto uno como el otro vocablo, al estar referidos por el legislador para el aseguramiento del servicio esencial que resulte afectado por la situación de buelga, tienen una significación análoga, pues incluso el concepto «mantenimiento» de un servicio, que equivale a su puesta a punto, implica o comprende el «funcionamiento» de ciertos elementos materiales o técnicos del mismo para que se pueda prestar el servicio tan pronto termina la situación de buelga.

Considerando: Que siendo un servicio esencial el que presta el Metropolitano de Madrid, y disponiendo el artículo 2 del referido Real Decreto de 14 de mayo último que, en cualquier situación de huelga, ha de asegurarse la prestación del mismo con carácter restrictivo, con el personal estrictamente necesario para que el servicio del Metro se realice en condiciones de máxima seguridad, no cabe dudar que tanto este precepto como la norma habilitante del citado Real Decreto, o sea, el artículo 10.2 del Real Decreto-Ley 17/1977 atribuye a la Administración la facultad de precisar los servicios minimos esenciales necesarios para garantizar el Servicio del Metro en cada situación de huelga que se presente, y aun siendo incuestionable que para fijar en cada caso las medidas restrictivas a adoptar deben ponderarse las circunstancias que concurren para adaptar las «medidas» a las «normas», a fin de que la restricción al derecho de huelga sea mínimo en cada supuesto que se dé, sin olvidar tampoco que, en todo caso, el servicio debe prestarse en condiciones de máxima seguridad para las personas usuarias, el personal de la Compañía y el mantenimiento del material de la misma; pero en el presente caso no parece que el Ministerio haya aludido o haya tenido presente, al dictar las normas impugnadas, las circunstancias o hechos concurrentes a la situación de huelga total de veinticuatro horas anunciada en esta capital, sino que, en atención a las distancias a largos desplazamientos existentes, desde muchos barrios de esta gran capital, para desplazarse los trabajadores desde el domicilio hasta el lugar del puesto de trabajo, así como los distintos horarios que existen de entrada y salida del personal y la gran masa urbana y suburbana de trabajadores en Madrid, son circunstancias todas ellas bien notorias, que por serlo no necesitan de prueba, por lo que esta Sala no estima excesivas las ocho horas fijadas por el Ministerio para la prestación del servicio (cuatro para el acceso y cuatro para el regreso del trabajo), por lo que, siendo discrecional apreciación la fijación de ese tiempo fijado y ser dicho horario la 
razón básica por la que la Sala de instancias se pronunció por la estimación del recurso, apreciación que no es compartida por esta Sala, entiende debe estimar el presente recurso de apelación, ya que, por otra parte, no se ha justificado por los recurrentes que las normas impugnadas restrinjan el derecho a la huelga, por la concurrencia de cualquier otro hecho o circunstancia, en más que lo estrictamente necesario para posibilitar el derecho al trabajo en condiciones de máxima seguridad a la gran masa del resto de trabajadores de esta gran capital, usuarios del Metropolitano, que es notorio no puede ser absorbida por el transporte público de superficie.

\section{Comentario}

Véase comentario a la Sentencia de 11 de julio de 1980 (núm. 10 de 1980 de este Repertorio).

Núm. 28. Sentencia de 31 de octubre de 1980. Contencioso-Administrativo. Sala IV. Ponente, E. Medina Balmaseda: ARTICULO 14 DE LA CONSTITUCION.

Mera cita del principio de igualdad de los españoles consagrado en el artículo 14 de la Constitución, que impide la desigualdad de trato en materia urbanística.

Considerando: Que precisamente por consistir las licencias municipales un reconocimiento del derecho de los peticionarios de las mismas, la denegación de su otorgamiento no puede tener otro fundamento que la infracción evidente de otro derecho que con la licencia se produzca, lo cual implica la naturaleza reglada que su concesión tiene, pues sólo en la vulneración de un derecho preeminente puede denegarse.

Considerando: Que en el supuesto de autos queda fuera de toda duda que el Ayuntamiento de Larraga tenga Plan General de Ordenación de la localidad, porque así lo certifica el secretario del mencionado Ayuntamiento, apareciendo igualmente que la construcción solicitada por don Angel Merino García está prevista en terrenos adjudicados como anejos a la vivienda; que efectivamente se ha autorizado a otros beneficiarios construcciones similares y que el Patronato informante de tales extremos no opone objeción alguna al mencionado proyecto.

Considerando: Que con estos datos, y dados los resultados obtenidos con la diligencia de reconocimiento judicial practicada en los autos y plano que obra en ellos, hay que concluir que la denegación de la licencia solicitada por el recurrente en primera instancia, señor Merino, es totalmente improcedente, porque el derecho que le asiste no infringe ningún otro que merezca o exija la limitación o denegación del suyo, razones todas que obligan a mantener la sentencia recurrida en aras de preceptos legales que prohíben su concesión y la existencia de otros, como son el principio de igualdad de los españoles, recogido en la Constitución de 28 de diciem. bre de 1978, cuyo artículo 14 lo proclama paladinamente en relación con el artícu. lo 348 , en este punto concreto, del Código Civil, que ampara la propiedad sin más limitaciones que las establecidas en las leyes. 
Núm. 29. Auto de 31 de octubre de 1980. Criminal. Ponente, M. García Miguel: ARTICULO 117 DE LA CONSTITUCION.

Principio de unidad jurisdiccional

Jurisdicción militar: carácter excepcional y restringido

El principio de unidad jurisdiccional conlleva la expansión de la jurisdicción ordinaria y el constreñimiento de las jurisdicciones especiales y excepcionales a los específicos supuestos legales en los que les venga attibuida expresamente la competencia.

La protección jurisdiccional a que se refiere el artículo 24 , en relación a la sección $1 .^{a}$, capítulo II, título I, y al artículo 53.2, se extiende a las personas físicas y jurídicas.

La jurisdicción ordinaria es la competente para conocer los delitos contra el honor de la Guardia Civil a tenor de lo dispuesto por la Constitución en su artículo 117.5 y la Ley de Protección Jurisdiccional de 26 de diciembre de 1978.

\section{Antecedentes:}

Autos de 2 de mayo de 1980,26 de septiembre de 1980 y 14 de octubre de 1980 (números 4, 16 y 24 de este Repertorio).

Considerando: Que como ha venido declarando esta Sala al resolver cuestiones de competencia análogas a las aquí planteadas, a efectos decisorios del tema objeto de enjuiciamiento, han de tomarse como base los dos principios fundamentales, y de superior rango, siguientes: el de unidad jurisdiccional, proclamado en el artículo 117 de la Constitución, a medida del cual se consagra la expansión de la jurisdicción ordinaria, $y$ el correlativo constreñimiento de las jurisdicciones especiales y excepcionales, cuya competencia para conocer queda delimitada a aquellos casos en los que el enjuiciamiento de determinados becbos punibles les venga atribuido por claros, expresos y terminantes preceptos legales; y el estatuido en el artículo 3.1 del Código Civil, conforme al cual las normas se interpretarán acudiendo no sólo a los métodos gramatical, lógico, histórico y sistemático, sino también al sociológico o a la realidad social del tiempo en el que deben ser aplicadas, ya que si las leyes han de estar en contacto con la vida real que constituye su razón de ser, es menester que, junto con los precitados elementos interpretativos, tradicionalmente tomados en consideración tanto por la doctrina científica como por la praxis judicial, se tenga en cuenta este nuevo elemento interpretativo, integrado por la serie de factores que revelan y plasman el espíritu de la comunidad en el momento histórico en el que la norma haya de ser aplicada, aunque en su aplicación se deba proceder con la máxima ponderación, a fin de evitar que, a pretexto de la utilización de tal elemento interpretativo, incurra el intérprete en la desviación, legalmente prohibida, de modificar o inaplicar la norma de que se trate.

Consinerando: Que la Ley de 26 de diciembre de 1978, sobre Protección de Derechos Fundamentales de la Persona, hace expresa referencia, en su artículo 1.2, a los derechos de reunión, expresión y asociación, a los de libertad personal, inviolabilidad de domicilio y de correspondencia y a otros, estableciendo en su artículo segundo que los delitos y faltas cometidos contra los derechos fundamentales de la persona, comprendidos en el ámbito de esta Ley, serán juzgados por los jueces y Tribunales de la jurisdicción ordinaria, y en su Disposición Transitoria Segunda se ordena que los Juzgados, Tribunales y autoridades de cualquier orden y jurisdicción distintos de la ordinaria que estuvieron conociendo de delitos de la reseñada índole se inhibirán inmediatamente a favor de la jurisdicción ordinaria. Siendo de notar que, aunque entre los derechos expresamente aludidos en la Ley no se encuentra el del honor, fue incorporado al texto legal por el Decreto de 20 de febrero de 
1979, de modo que no queda la menor duda respecto a la atribución a la jurisdicción ordinaria de la competencia para conocer de los delitos atentatorios este bien jurídico al que se hace extensiva la protección penal, así como la jurisdicción a quien compete prestar tal protección, quedando, pues, como único problema, el relativo a si el honor al que se refiere el precepto es el individual o de las personas físicas, o si ha de entenderse extendido también a las personas juridicas, cuerpos, instituciones, clases del Estado u organismos públicos o privados.

CONSIDERANDO: Que la cuestión últimamente enunciada ba de ser resuelta en sentido amplio, es decir, en el omnicomprensivo de todo atentado al bonor, sea quien fuere la víctima, o, persona natural o jurídica ofendida, en cuanto que en el Título I de la Constitución, que lleva por denominación «De los derechos y deberes fundamentales», no se bace distinción alguna entre una y otra de las dos clases de personas conocidas en Derecbo, y asimismo, en consonancia con ello, en el articulo 24, incluido en la sección $1 .^{a}$ del capitulo 2 de dicho Título, se alude a los derechos fundamentales y las libertades públicas sin restringirlas a una sola de las dos referidas clases de personas, interpretación que viene abonada por el contenido de la propia Constitución en vigor, ya que de los articulos 16.1, 16.3, 22, 27.6, 27.7, 27.8, 38.1 $y 34$, resulta que no son únicamente los derechos individuales los proclamados $y$ tutelados, ya que en dichos preceptos se hace expresa referencia, respectivamente, a las comunidades, confesiones, asociaciones, personas físicas y jurídicas, centros docentes, sindicatos y fundaciones.

Considerando: Que en virtud de lo dispuesto en los textos de Derecho positivo a que se alude en los precedentes considerandos, interpretados a la luz de los principios fundamentales y criterios interpretativos expuestos en el primer considerando de esta resolución, es claro que se ha de concluir en el sentido de que procede resolver el presente conflicto jurisdiccional a favor de la jurisdicción ordinaria y, dentro de ella, del Juzgado de Instrucción número 3 de los de Madrid, a quien, con testimonio de esta resolución, se remitirán las actuaciones, comunicando lo resuelto al excelentísimo señor capitán general de la Primera Región Militar.

\section{Comentario}

Véase auto de 26 de septiembre de 1980, núm. 16 de este Repertorio.

\section{Núm. 30. Sentencia de 31 de octubre de 1980. Criminal. Ponente, B. Gil Sáez: ARTICULO 4 DE LA CONSTITUCION.}

\section{Bandera española: concepto y utilización}

Se comete el delito de ultraje a la bandera de España tipificado en el artículo 123 del Código Penal, aun cuando se ofende a una representación de la misma, con tejidos y colores que le son propios y le dan apariencia de tal, conforme a lo dispuesto en el artículo 4 de la Constitución.

Considerando: Que razones de metodología procesal y la propia naturaleza del motivo obligan a examinar primeramente el segundo de los articulados en el recurso interpuesto por la representación de los procesados J. V. A., S. A. G. G. y M. C. R., al amparo del núm. 2..$^{\circ}$ del art. 849 de la Ley de Enjuiciamiento Criminal, alegando error de hecho en la apreciación de las pruebas derivado del contenido de documento auténtico que demuestra la equivocación del Tribunal de Instancia, designado como 
documento de aquella naturaleza el acta del juicio oral en los particulares referentes a las manifestaciones hechas por los expresados procesados en el sentido de que no tomaron parte en el acto de coger la bandera, ni se pusieron de acuerdo para ello, alegación que vuelve a transcribirse en la interposición y desarrollo del motivo al citarse las declaraciones prestadas por los mismos en las diligencias iniciadas por la Guardia Civil, así como en el sumario ante el Juzgado, ratificadas posteriormente en el acto del juicio oral, afirmando que el procesado G. A. S., si bien cogió la bandera, se limitó a guardarla y esconderla bajo un puente, alegación y motivo enteramente inviable a los efectos casacionales postulados, porque aparte de no haberse mencionado ningún extremo, dato o particular que pudiera contradecir o modificar el relato probatorio, el documento citado del acta del juicio oral, si bien tiene autenticidad formal por la fe judicial del secretario que la refrenda y autenticidad intrínseca respecto a la celebración del acto y su fecha, personas intervinientes y conclusiones de las partes legitimadas, carecen totalmente de valor probatorio vinculante en cuanto a las manifestaciones de voluntad que pudieran hacer los testigos, porque no encierran verdades autónomas e incontrovertibles, sino simples apreciaciones personales sujetas al grado de veracidad y de ética moral y legal de quien las vierte, siendo y constituyendo meros elementos de juicio y prueba sometidos a la discrecional y soberana valoración del juzgador penal, en unión de las restantes existentes en los autos, a los fines de formación del juicio cognoscitivo de conciencia preceptuado en el artículo 741 de la citada Ley procesal, incurriendo el motivo contemplado en las causas de inadmisión cuarta y sexta del artículo 884 de la propia Ley, que en este trámite lo son de desestimación.

Considerando: Que, dentro de la rúbrica general de «Delitos de traición» del capítulo I, título II, del libro $2 .^{\circ}$ del Código Penal, queda tipificado en el artículo 123 un supuesto de traición ideal que difiere de las conductas materiales casuísticamente descritas en los tres artículos que le anteceden, en la que aparece ante todo el honor de la Nación española como objeto de ataque, en los casos de ultraje a la misma o al sentimiento de su unidad, así como a sus símbolos o émblemas, precepto incorporado al texto refundido del Código Penal de 1944, proviniente de la Ley de Seguridad del Estado, cuyos precedentes se encuentran a su vez en la Ley de 23 de marzo de 1908, llamada de Jurisdicciones, y en el artículo 231 del Código Penal de 1928, siendo aquél modificado por la Ley de 8 de abril de 1967, que extendió el ámbito delictivo a los «ultrajes al Estado o su forma política», que todavía conserva tal texto vigente actual, cuyos bienes jurídicamente protegidos se contraen a la nación española, al sentimiento de unidad e integridad, al Estado y su forma política y a los símbolos y emblemas, que son los signos externos que poseen la cualidad de representar a determinadas realidades, que no son parte enteramente señaladas en el precepto respectivo, pero que se desprende de las disposiciones de nuestro ordenamiento jurídico positivo que atribuyen a ciertos signos la indirecta índole representativa cuya consideración merece la bandera nacional, conforme al Código de Justicia Militar, la derogada Ley Orgánica del Estado y el artículo 4 de la vigente Constitución, así como la jurisprudencia aplicada a este elemento objetivo (Sentencias de 22 de diciembre de 1909, 15 de octubre de 1947 y 21 de octubre de 1969). La acción que configura el delito es la de ultraje, equivalente a injuria, cuya concepción es la misma que la definida en el artículo 457 del Código citado, según tiene reconocido la doctrina de esta Sala, requiriéndose como elemento básico de la acción típica el animus iniurandi, o sea, el propósito de deshonrar, vejar y menospreciar a los objetos que entren en los bienes protegidos penal mente por cualesquiera de los modos o formas que la acción de injuriar admite, como la de arrancar y pisotear la bandera (Sentencia de 6 de junio de 1908). 
Considerando: Que a tenor de lo expuesto, y siendo así que los hechos probados de la sentencia impugnada arrojan sustancialmente que el día 4 de diciembre de 1977 los procesados M. C. R., S. E. D. y J. V. A., en unión de otro no recurrente y de S. A. G. G., después de haber tomado parte en una manifestación celebrada en Almería, proautonomía de Andalucía, cuando regresaban en un vehículo Land-Rover a Dalias, conducido por el último (y cuya actuación será considerada separadamente), al pasar por un puesto de la Cruz Roja instalado para auxilio en la carretera N-340, junto al kilómetro 97,100 , del término municipal de Vicar, en cuyo edificio ondeaba una bandera nacional y otra de ésta institución, poniendo en práctica lo que previamente habían acordado entre ellos, detuvieron el vehículo y se apearon todos, excepto el conductor, que continuó algunos metros, en busca de sitio para aparcar debidamente, regresando después aquéllos tras haber quitado la bandera nacional que allí ondeaba y haberla arrojado debajo de un puente, de cuya transcripción, apostillada con la aseveración fáctica del primer Considerando: que los procesados mencionados, con sus actos y conducta, menospreciaron y ultrajaron la referida enseña nacional, como lo evidenciaba el arrancarla del lugar en que visiblemente ondeaba, arrojándola seguidamente al interior de un puente, aparece inequívocamente reflejada la injuria, ofensa, agravio, burla, escarnio, afrenta, desaire y baldón, inferido a la insignia y símbolo nacional por antonomasia de la nación española, y con ello de correcta aplicación la calificación jurídica de ultraje a dicha enseña, tipificada y penada en el artículo 123 ya expresado, careciendo de consistencia fáctica y legal el motivo único por corriente infracción legal del recurso interpuesto por la representación del procesado S. E. D., así como el primero acogido al mismo cauce procesal de los procesados M. C. M. y J. V. A., autores materiales de los hechos, cuya alegación sustancialmente consistentes en que tal ultraje sólo se da cuando real y verdaderamente se ofende la bandera nacional, pero no cuando con tejidos y colores propios se forma una apariencia de la misma, extremo regulado en el artículo 4 de la Constitución española, que determina sus características y reconoce los propios de las regiones autónomas, que se utilizarán junto a aquélla en sus edificios públicos y en sus actos oficiales, pues si se trata de apariencia de banderas que ondean en otros lugares o sitios, como obras, manifestaciones o actos donde no deben mecerse, izarse $u$ ondearse al aire, nunca se tratará de la bandera nacional o de las Comunidades Autónomas, lo que también se ratifica en el Decreto de 24 de noviembre de 1978, probibiendo su uso a los partidos, sindicatos, asociaciones o entidades privadas de toda indole, como símbolos distintivos y diferenciadores de los citados grupos, asociaciones o entidades, por lo que la que ondeaba en el puesto de la Cruz Roja no era la propia de la Nación, sino una apariencia de la misma, al emplear sus colores y franjas, sin que en el relato probatorio se afirme que los procesados tuvieran intención de ultrajar a tal enseña, sobre cuyas alegaciones cabe distinguir, matizar y objetar: a) que la confusa y prolija exposición sobre la aparente y propia bandera no representa más que una lucubrativa y sofisticada alegación, incierta, ineficaz y de mal gusto, pues el signo representativo es el indicado por la estructuración, colores y franjas señaladas en la Constitución y sea cualesquiera el lugar, sitio, emplazamiento, colocación, paraje, ámbito, punto, recinto, local, edificio, zona, etc., donde ondee, será el emblema por excelencia, puesto que una cosa es su representatividad y su significación y otra el buen o mal uso regulado previsto en el Decreto citado de noviembre de 1978, posterior a los hechos, que de resultar indebido o abusivo por personas o entidades resulte sancionable en otro orden del ordenamiento jurídico español; b) que los hechos probados afirman terminantemente que en un puesto oficial de socorro de la humanitaria institución de la Cruz Roja ondeaba tanto la bandera oficial española como la propia de aquella entidad, lo cual era perfectamente lícito, y al suponerse que la primera era una mera apariencia por coincidir su formación externa con su conformación oficial es afirmación incongruente y contra- 
dictoria, con el vinculante e intangible relato probatorio que por sí misma es causa de desestimar en este trámite a tenor del número tercero del artículo 884 de la Ley Procesal; c) que la actuación descrita por el relato fáctico era claramente ofensiva y ultrajante para integrar el delito imputado y penado, cuyos vocablos no se usaron por el Tribunal para evitar el socorrido recurso de forma de predeterminación del fallo, quedando por ello más explícitamente reflejado en la aseveración cognoscitiva del primero de los Considerandos, siendo indudable que la acción premeditada de bajar del coche, arrancar y tirar la bandera bajo un puente era un móvil perverso de injuriar a tal símbolo en presencia de las personas que se encontraban en el puesto de socorro, cuyos sentimientos fueron agredidos al representar en pequeña escala los que integraban por tradición, historia, lenguaje, cultura y territorio nacional los componentes del pueblo español, siendo bien significativo que el ultraje fuera contra la insignia nacional, mientras respetaban la bandera de la Cruz Roja, de tan diferente entidad, valor y representatividad, cuya conducta es por su propia índole tan ostensible y manifiesta, que se califica por sí misma, sin necesidad de remarcarla especialmente; d) que el hecho de concertar previamente la acción, de tener el vehículo frente al lugar donde la bandera se encontraba izada, bajar los autores materiales y hoy recurrentes condenados, S. E. D., M. C. M. y J. V. A., junto al procesado no recurrente, llegando hasta el sitio donde fue arrancada, no cabe en buena lógica y hasta por sentido común atribuir a tal acción otro móvil que el voluntario, libre y pérfido propósito que el ofender y menospreciar la bandera, como en supuestos similares tiene declarado esta Sala, tales como sacar con violencia una bandera del lugar en que está sujeta y pisarla (sentencia de 6-VI-1968), hacerla caer deliberadamente al suelo y arrastrarla (sentencias de 25-V-1959 y 21-XI-1969); siendo un delito de simple actividad que se consuma cuando los actos ofensivos son captados o presenciados por alguna persona ajena (sentencia de 26 de junio de 1969) concurriendo el ánimo de vituperar como dolo específico necesario en esta infracción, cuya finalidad e intención resulta clara, manifiesta y probada en la premisa narratoria y del contexto de la resolución, y $e$ ) que finalmente habiéndose invocado la falta de intención de injuriar de los inculpados en general, conforme al artículo $1 .^{\circ}$ del Código Penal, tal invocación carece de sentido lógico y se vuelve en contra de quien lo esgrime, conforme al párrafo segundo del precepto, por cuanto en virtud de este precepto se presume la consciencia de la antijuridicidad, que comprende al dolo característico de cada una de las figuras previstas y sancionadas en la norma que se aplica, cuya prueba en contrario corresponde suministrarle al inculpado (sentencias de 18 de diciembre de 1973, 15 de mayo de 1975 y 27 de febrero de 1975), lo que consecuentemente conlleva a rechazar por injustificados e improcedentes los dos motivos examinados en cuanto a los procesados señalados, reputando infringido por aplicación indebida el artículo 123 de referencia, que apareciendo correcta y acertadamente calificado por la Audiencia Provincial juzgadora, procede mantener y confirmar.

Considerando: Que el concepto de ultraje lo constituye toda expresión proferida de palabra o por escrito o acción ejecutada con el móvil criminal y perverso de ajar o vituperar abiertamente a cualquiera de los elementos comprendidos en la norma punitiva del artículo 123 del Código Penal, al que se contraen las consideraciones precedentes, y por ello es denigrante y constituye menosprecio el tirar al suelo deliberadamente una insignia de tan alto significado como tiene la bandera nacional, que merece respeto, consideración y estima por parte de todos los españoles, sin distinción de credos políticos o confesionales, por representar a la total unidad de nuestra Patria, integrada por sus regiones, que componen, por fusión de los diversos matices regionales y locales, la unidad inquebrantable de la Nación (sentencia de 21 de noviembre de 1969), y siendo así que el relato cognoscitivo de hechos 
probados, tras reterir que al regreso de los procesados de la manifestación en Almería en favor de la autonomía andaluza, al llegar al puesto de la Cruz Roja donde ondeaba la bandera nacional, en unión de la de esta institución, poniendo en práctica lo previamente acordado entre aquellos que ocupaban el coche, conducido por el también procesado y condenado S. A. G. G., detuvieron el vehículo y se apearon todos, excepto éste, que continuó algunos metros en busca de sitio para aparcar, y cuando regresaron aquéllos, después de haber quitado la bandera, que fue arrojada debajo de un puente, al enterarse de ello el citado G. G., se marchó con el cocbe, dejándoles a los otros en tierra, cuya expresa y terminante afirmación arroja dos extremos fundamentales para valorar su actuación, consistente el primero en que el relato no aclara cuál pudo ser el acuerdo que los usuarios del vehículo pudieron haber tomado, y si éste comprendía o no al conductor recurrente, duda muy significativa que en forma alguna puede presumirse le alcanzara por estar en total contradicción con su conducta subsiguiente y no caber en la órbita restrictiva penal presumir o deducir extremos no dilucidados, ni aclarados, en contra del reo, y por otra parte que, al regresar de su acción los partícipes materiales del hecho, y enterarse de ella el citado G. G., se marchó con el coche, dejando a los mismos en tierra, actuación que sí aclara con más precisión que tuvo conocimiento del hecho delictivo después de consumado, que no tomó participación directa o indirecta en el mismo, que tampoco tuvo oportunidad de presenciarlo por cuanto fue realizado mientras él hacía la maniobra de aparcar el vehículo, y que cuando se enteró del mismo, su reacción no pudo ser más explícitamente opuesta a lo sucedido, abandonando a sus compañeros de viaje, lo que manifiestamente significaba sus sentimientos, propósito y convicción contraria a la infracción cometida, de la que no resultan elementos de juicio en la resolución dictada para reputarlo de coautor en el delito calificado por la triple razón de que no existe constancia precisa que se hubiera concertado previamente con los demás usuarios del vehículo para realizar la infracción punible llevada a efecto (aunque hubieran acordado detenerse en el sitio en que lo hicieron para alguna otra finalidad no determinada); porque no intervino en los hechos en ninguna de las formas requeridas para considerarle partícipe, por lo que su acción careció de antijuridicidad ante la norma penal y porque su significada repulsión al acto cometido excluía enteramente su voluntariedad de realizarlo, faltando el elemento subjetivo de lo injusto, y consiguientemente su culpabilidad personal y voluntaria, lo que lleva a acoger el extremo del recurso que concretamente hace referencia a este procesado para reputarlo exento de responsabilidad penal, casando y anulando respecto al mismo la sentencia pronunciada por la Audiencia Provincial de Almería con fecha 8 de junio de 1979, dictando en su lugar la procedente en derecho.

\section{Comentario}

La Sentencia de 31 de octubre de 1980 estudia con gran precisión el concepto de «bandera de España» del artículo 4 de la Constitución a propósito de calificar la conducta consistente en sustraer una bandera nacional (supuesta en principio) y artojarla debajo de un puente. Contra la pretensión de la defensa se concluirá tajantemente que, con independencia de que la bandera de España se utilice incorrectamente con respecto a lo estipulado en el Decreto de 24 de noviembre de 1978, cuando se represente el símbolo que describe el artículo 4 de la Constitución y se ultraje dicho símbolo, se está ultranjando la bandera de España.

Del Considerando que transcribimos destaca por una parte la aplicación directa de la Constitución sobre el Decreto de 24 de noviembre de 1978, que se circunscribe a regular la utilización de la bandera. De otra parte se alcanza la conclusión, y no podía ser menos, que la bandera es un símbolo que se representa, en el caso de la española, mediante tres 
franjas horizontales: roja, amarilla y roja, siendo la amarilla de doble anchura que cada una de las rojas; pues bien: cualquier representación de estas características es, a los efectos de la Constitución, la bandera española, con independencia de su incorrecta utilización.

\section{Núm. 31. Sentencia de 8 de noviembre de 1980. Criminal. Ponente, J. H. Moyna} Ménguez: ARTICULO 117.5 DE LA CONSTITUCION.

\section{Ambito estrictamente castrense: concepto Jurisdicción militar}

La jurisdicción militar se extiende al ámbito estrictamente castrense que viene definido objetivamente por los llamados lugares o espacios militares. Los cuarteles de la Guardia Civil son a estos efectos «ámbito estrictamente castrense».

Considerando: Que aceptando que los miembros de la Guardia Civil se hallaban en el ejercicio de las funciones señaladas en la Ley de 4 de diciembre de 1978 - artículo 2. $, 2, b$ ) - al tratar de evitar en el cuartel la comisión de un delito de robo con armas, no puede afirmarse la competencia de ésta jurisdicción ordinaria, como propicia el recurrente, porque el artículo $50^{\circ}, 1$, párrafo segundo, de dicha Ley mantiene para la Guardia Civil el Fuero militar, y este Fuero atribuye la competencia a la jurisdicción de guerra para los delitos que sin estar comprendidos en el artículo 16 del Código de Justicia Militar, como no lo está el enjuiciado, se cometen en los lugares militares que menciona el artículo $90^{\circ}, 1 .^{\circ}$, a) de este último texto legal, entre los que se encuentran los cuarteles; a esta misma conclusión coadyuva la interpretación sistemática y lógica del artículo 5. $\mathrm{de}$ la Ley de Policía antes citada, pues si los delitos cometidos «por» los miembros de la Guardia Civil en el ejercicio de las funciones que dicha Ley les encomienda serán enjuiciados par la jurisdicción ordinaria «salvo que por razón del lugar sea competente otra jurisdicción», esta misma salvedad debe hacerse para los delitos que se cometan «contra» los mismos, con fuerza lógica reforzada por el hecho de conservar, en este caso, el Fuero militar; y como razón decisiva basta traer, finalmente, a colación el artículo 117.5 de la Constitución española, que al reconocer el principio de unidad jurisdiccional, restringe el ejercicio de la jurisdicción militar al «ámbito-estrictamente castrense», ámbito que en el aspecto objetivo viene definido por los llamados lugares o espacios militares, y entre ellos, comprendidos, con significación propia y relevante, los locales destinados al acuartelamiento; todo ello conduce a desestimar el motivo de casación formulado por la vía del número $10^{\circ}$ del artículo 849 de la Ley de Enjuiciamiento Criminal, invocando la infracción del artículo $5 .^{\circ}, 1$, párrafo segundo, de la Ley de Policía de 4 de diciembre de 1978, debiendo ser mantenido el auto de la Audiencia Provincial, que rechazó la competencia por inhibitoria propuesta.

\section{Comentario}

La sentencia practica una interpretación del concepto «ámbito estrictamente castrense», que la Constitución no define en su artículo 117.5 , y que atribuye a los cuarteles de la Guardia Civil en razón al Fuero militar de los miembros de la misma. Esta circunstancia hace que, aunque el delito no sea por su naturaleza enjuiciable por la jurisdicción militar, sea ésta competente por razón del lugar en que se cometió. Dentro de estas premisas el razonamiento es irreprochable, pero no pueden descartarse otras soluciones en el futuro más acordes al principio expansivo de la jurisdicción ordinaria que consagra la Constitución en el artículo 117. 
Núm. 32. Sentencia de 12 de noviembre de 1980. Contencioso-Administrativo. Sala III. Ponente, F. Roldán Martínez: ARTICULO 9.3 DE LA CONSTITUCION.

\section{Principio de legalidad \\ Principio de reserva de ley}

La interpretación de las normas sancionadoras debe hacerse siempre en el sentido más favorable al inculpado (principio pro reo). Los principios de legalidad y jerarquía normativa consagrados en el artículo 9.3 de la Constitución determinan que la falta de cobertura legal de hechos objeto de sanción hacen que no sean éstos determinantes de culpabilidad.

\section{Antecedentes:}

Véanse Sentencias de 11 de junio de 1979 (núm. 5 del Repertorio 1979), 25 de junio de 1980 (núm. 6 de este Repertorio 1980) y del 21 de octubre de 1980 (núm. 26 de este Repertorio).

Considerando: Que la empresa recurrente Filmófono, S. A., propietaria del cinematógrafo «Palacio de la Música», de Madrid, impugna la resolución del Consejo de Ministros de 25 de agosto de 1978, que la sancionó con la multa de 500.000 pesetas como responsable de una infracción administrativa por no haber exhibido películas españolas por espacio de cincuenta y seis días durante el año 1977, siendo el tema a resolver el de inobservancia de la llamada «cuota de pantalla», obligación que en beneficio del cine español había sido impuesta por una normativa, sin rango de ley formal, y que como ya tuvo ocasión de pronunciarse esta Sala por sentencia de 21 de octubre de 1980 resolviendo el recurso núm. 305.870/79 en un caso análogo promovido por la empresa del cine «Novedades», también de esta capital, al no estar establecida dicha normativa sancionadora y limitativa de la libertad de comercio desde sus orígenes por una ley formal, la sentencia de esta Sala de 9 de julio de 1979 declaró nulos los artículos 17 y 19 del Real Decreto de 11 de noviembre de 1977 sobre actividades cinematográficas, que era la normativa que en ese año 1977 regulaba la «cuota de pantalla», por lo que en la fecha en que fue dictada la resolución aquí impugnada en 25 de agosto de 1978 implicaba una específica y grave limitación contra la libertad de comercio y principios de reserva de ley y de legalidad que fueron proclamados y garantizados por la Constitución, por lo que al desaparecer la cobertura legal por la nulidad de pleno derecho, declarada por la sentencia de esta Sala que ya se deja citada, no son de aplicar para los hechos ocurridos en 1977 las disposiciones sancionadoras contenidas en aquellos artículos anulados, sin que, por otra parte, puedan darse efectos retroactivos en esta materia sancionadora a la Ley posteriormente aprobada en 10 de enero de 1980 y el Real Decreto de 11 de julio de 1980 sobre protección del cine nacional, porque iría contra la norma general contenida en el artículo 4.2 del título preliminar del Código Civil y el principio pro reo, sin que sean de apreciar circunstancias especiales para hacer una especial imposición de costas.

\section{Comentario}

Véase comentario Sentencia de 21 de octubre de 1980 (núm. 26 de este Repertorio). 


\section{Núm. 33. Sentencia de 2 de diciembre de 1980. Criminal. Ponente, J. Moyna Ménguez: ARTICULO 23.1 DE LA CONSTITUCION.}

\section{Derecbo a participar en los asuntos públicos}

El derecho de los ciudadanos a participar en los asuntos públicos tiene una de sus expresiones en el derecho a participar en las elecciones locales. El ejercicio de dicho derecho está garantizado penalmente.

Considerando 2.0: Que el artículo 23.1 de la Constitución española reconoce a los ciudadanos el derecbo a participar en los asuntos públicos, directamente o por medio de representantes «libremente» elegidos en elecciones periódicas por sufragio universal, y la garantía penal de este derecho viene legalmente prevista en el Título VIII de las normas electorales aprobadas por Real Decreto-Ley de 18 de marzo de 1977, aplicable a las elecciones de ámbito local por remisión del artículo 41, in fine, de la Ley de 17 de julio de 1978; y entre las categorías delictivas definidas en aquellas normas, el artículo 86.1 , bajo el común dolo específico de impedir o dificultar el ejercicio de su derecho a cualquier elector, se refiere en los dos primeros números a unas concretas conductas comisivas, cerrando el dispositivo sancionador con el tipo abierto del apartado $3 .^{\circ}$, dirigido a quienes «de cualquier modo» persiguen el aludido propósito; y es, precisamente, en este precepto penal en el que subsume el Tribunal de instancia la acción del cartero de Villablanca, candidato por el PSOE en las pasadas elecciones locales, que con el fin de impedir que numerosos ancianos ejercieran su derecho de sufragio, por suponer que lo harían a favor de otro partido político, retuvo los sobres a ellos dirigidos con la documentación electoral, impidiendo su voto por correo.

Considerando: Que frente a esta sentencia condenatoria se alza la impugnación del acusado, expresando como motivo de fondo la aplicación indebida del artículo 86.1, inciso 3, de las normas electorales, por entender que la acción del cartero no supuso para los vecinos un impedimento insalvable, ya que pudieron ejercer su derecho directa y personalmente en las mesas electorales; pero al razonar así se desconoce que la opción por dicho medio fue, precisamente, porque preveían que en la fecha de la votación no podrían acudir al lugar en que les correspondería votar, además de que, una vez remitida al elector que solicita el voto por correo la documentación pertinente, por prescripción del artículo 57.2 de dichas normas, se anotará aquella solicitud «a fin de que en el día de la votación no se reciba el voto personalmente»; también se rechaza la alegación en que niega el acusado el dolo específico de impedir el ejercicio del derecho de sufragio a varios electores, porque esta manifestación - sin ningún asidero en los hechos probados- se enfrenta abiertamente con el relato que describe, para la correcta construcción del silogismo judicial, dicho elemento subjetivo del injusto; y, finalmente, no puede prosperar el posible error sobre las circunstancias del hecho, que es la razón -implícita- del motivo de casación en la forma, porque en la documentación normalizada para el ejercicio de este derecho, que arranca del Real Decreto de 15 de abril de 1977, dictado para la primera consulta electoral de dicho año, y que virtualmente es reproducida en el Real Decreto de 29 de diciembre de 1979 para las elecciones locales, los sobres del voto por correo son del mismo formato y leyenda, con la salvedad del tipo de elección y año, e iguales también los trámites del procedimiento de voto por correo, y si los sobres iban dirigidos a los electores, es imposible excusar, por error, que se hiciera la entrega en la mesa electoral el mismo día de la elección, argumentos todos que llevan a desestimar el único motivo de casación admitido por la vía del número primero del artículo 849 de la Ley de Enjuiciamiento Criminal. 


\title{
Comentario
}

La Sentencia comentada cita simplemente el principio de participación consagrado en el artículo 23.1 de la Constitución, pues la garantía penal del referido derecho está prevista al margen del citado artículo.

Véase, sobre el tema de la participación, M. Sánchez Morón, La participación del ciudadano en la Administración pública, en «C. E. C.», Madrid, 1980, y P. Lucas Murillo, Notas sobre el proceso de participación política, en «R.P.C.», núm. 1, págs. 67 a 80 , aunque los citados trabajos no tratan los aspectos penales a que se refiere esta sentencia.

\section{Núm. 34. Sentencia de 22 de diciembre de 1980. Criminal. Ponente, F. Cotta y Márquez de Prado. (Cita la Constitución española.)}

\author{
Principio de unidad jurisdiccional \\ Jurisdicción militar: carácter excepcional y restringido
}

Se cita la Constitución para afirmar que no ha derogado el artículo 6.2 del Código de Justicia Militar, alcanzándose la misma conclusión que en las Sentencias de 2 de mayo y Autos de 26 de septiembre y 14 y 31 de octubre (núms. 16, 24 y 29 de 1980 de este Repertorio).

\section{Antecedentes:}

Véanse Autos de 2 de mayo de 1980, 26 de septiembre de 1980, 14 de octubre de 1980 y 31 de octubre de 1980 (núms. 4, 16, 24 y 29 de este Repertorio).

Considerando: Que el número $60^{\circ}$ del artículo 19 de la Ley de Enjuiciamiento Criminal autoriza a los procesados y a la parte civil, tanto actora como responsable, para promover y sostener competencias dentro de los tres días siguientes al en que se les comunique la causa para calificación, previniendo el artículo 26 , párrafos $1 .^{\circ}$ y $2 .^{\circ}$, de dicha Ley que las competencias lo podrán ser por inhibitoria o por declinatoria, y que el uso de uno de estos medios excluye absolutamente el del otro, así durante la sustanciación de la competencia como una vez que ésta se halle determinada; pero ello no impide, en supuestos excepcionales como el presente, en que una variación sustancial de las reglas de competencia elimina específicos hechos delictivos de la esfera de conocimiento de un Tribunal determinado o de una determinada jurisdicción, que las partes citadas anteriormente puedan de nuevo suscitar la cuestión de competencia cuando aquellos Tribunales o jurisdicciones no hayan acatado el mandato imperativo en que la modificación de la competencia objetiva consista, pues siendo las cuestiones jurisdiccionales de orden público y de orden público las normas que delimitan la competencia de los distintos organismos judiciales, cualquiera que sea la jurisdicción a que pertenezcan, como acto de auxilio a la Administración de Justicia habrá de calibrarse de nuevo el planteamiento del problema, que tiende a evitar sea dictada resolución definitiva por juez o jurisdicción incompetente para hacerlo, y si esto es así, y así es, no cabe la menor duda de que la presente cuestión ha sido planteada en tiempo y forma hábil y que, por tanto, nunca podrá ampararse en una violación inexistente de normas de procedimiento la resolución de rechazarla de plano.

Considerando: Que el delito de injurias u ofensas claras o encubiertas a los ejércitos o a instituciones, armas, clases o cuerpos determinados de los mismos a 
que se refiere el artículo 317 del Código de Justicia Militar vigente en la fecha de planteamiento de la presente cuestión, ha sido eliminado de la órbita competencial de la jurisdicción castrense por la Ley 62/1978, de 28 de diciembre, de Protección jurisdiccional de los Derechos Fundamentales de la Persona y el Real Decreto 342/ 1979, de 20 de febrero, legislativo sobre ampliación del ámbito de la referida Ley, en cuyas disposiciones se establece que serán enjuiciados por los jueces y Tribunales de la jurisdicción ordinaria los atentados contra las libertades de expresión, reunión y asociación, la libertad y secteto de la correspondencia, la libertad religiosa y la de residencia, la garantía de la inviolabilidad del domicilio, la protección jurídica frente a las detenciones ilegales $y$, en general, frente a las sanciones impuestas en materia de orden público, así como los derechos al honor, a la intimidad personal y familiar y a la propia imagen, el secreto de las comunicaciones telefónicas y telegráficas, la libre circulación por el territorio nacional, la libre entrada y salida de España en los términos legales, la libertad de cátedra y la libertad sindical, ordenándose del mismo modo en dichas disposiciones no sólo que las causas que se encuentren en trámite, por acciones u omisiones comprendidas en el ámbito de aplicación de aquella Ley, se acomoden a las prescripciones señaladas en ella, cualquiera que fuera su estado, incluso en los supuestos en que hubiere recaído sentencia y ésta no fuere firme, sino también que los Juzgados, Tribunales y autoridades de cualesquiera orden y jurisdicción distintas de las que componen la jurisdicción ordinaria, que estuvieren conociendo de actuaciones comprendidas en el ámbito de aplicación de la referida Ley, se inhibirán inmediatamente en favor de dicha jurisdicción, que continuará la tramitación de los procesos en el modo y forma establecidos por la Ley procesal sin más modificaciones, en cuanto a requisitos de procedibilidad (que es a los que se refiere), que los que resulten del artículo $4 .^{\circ}$ de la Ley de Protección jurisdiccional de los Derechos Fundamentales de la Persona, el cual establece, en su número cuatro, y con relación a las ofensas dirigidas a la autoridad pública, Corporaciones o clases determinadas del Estado - entre las que se encuentran los ejércitos, instituciones, armas, clases y cuerpos determinados de los mismos--, y lo dispuesto en el capítulo VIII, del título II, del libro II, del Código Penal, que ninguno de estos delitos sufrirá alteración en su actual sistema de persecución como delitos públicos.

Considerando: Que sentado lo anterior, es claro que la Audiencia Provincial de Barcelona ha infringido todas las disposiciones de que se deja hecho mérito, pues si bien es cierto que la Constitución española no ba derogado el artículo 6.2 del Código de Justicia Militar vigente en aquella época, ni tampoco lo ba becbo la Ley ya reseñada de 26 de diciembre de 1978, sí ban extraido las dos, sin embargo, de tal precepto, a los paisanos que cometan los delitos que en el mismo se recogen, los que pasarán a ser enjuiciados por la jurisdicción ordinaria como posteriormente ha sancionado ya con carácter indubitado la Ley 9/1980, de 6 de noviembre, de reforma del Código de Justicia Militar, y como aquellas normas, rectoras en su materia de las competencias objetivas de los jueces y Tribunales, son de orden público $y$, por tanto, de obligado e ineludible acatamiento, es visto que aun cuando cambie la jurisdicción enjuiciante, varíe el procedimiento a seguir y sean distintas las disposiciones sustantivas que deban aplicarse, ninguna de estas quiebras, ni aun en su conjunto, pueden prevalecer contra la imperatividad de tales normas o competenciales, que han de mantenerse y cumplirse aun a sabiendas de padecer la continencia de la causa.

Considerando: Que por todo ello es incuestionable la procedencia de librar oficio inhibitorio a la jurisdicción militar, requiriéndola para que decline el conocimiento de la causa a que se refiere esta resolución, por corresponder el mismo, 
según la Ley, a los jueces y Tribunales de la jurisdicción ordinaria; concretamente, a la sección 2. a de la Audiencia Provincial de Barcelona.

\section{Comentario}

Véase Auto de 26 de septiembre de 1980, núm. 16 de este Repertorio.

\section{B) Resoluciones de la Dirección General de los Registros}

\section{R. 4. Resolución de la Dirección General de los Registros de 7 de mayo de 1980 (Repertorio Aranzadi 2.964/1980) : ARTICULOS 14 Y 39.2 DE LA CONS- TITUCION.}

Principio de igualdad de los bijos ante la Ley con independencia de su filiación

\section{Antecedentes:}

Véase Resolución de la Dirección General de los Registros y del Notariado de 8 de mayo de 1980 (R. 3 de este Repertorio de 1980).

Considerando: Que la cuestión fundamental que plantea el recurso es la de decidir si puede inscribirse en el Registro español el nacimiento de quien aparece reconocido en el expediente como hijo por un español, casado al tiempo de la concepción de aquél, estando de acuerdo con esta confesión la que en el Registro francés consta como madre y afirma ser soltera.

Considerando: Que, conforme al artículo 15 de la Ley del Registro Civil (R. 1957, 777 y N. Dicc. 25893), en el Registro español constarán los hechos inscribibles que afecten a españoles, como lo son, sin distinciones por la clase de filiación, los hijos de español (cfr. art. 17.1. ${ }^{\circ}$ C. Cív.), y, por otra parte, no es necesario para proceder a la inscripción que se dé una seguridad, legal o moral, plena sobre la nacionalidad del sujeto, según se desprende del párrafo $2 .^{\circ}$ del artículo 66 del Reglamento; así, pues, la inscripción de nacimiento ha de practicarse en casos como el presente, aunque, por los motivos que sean, la filiación paterna de la que se deriva la nacionalidad no pueda tener acceso al Registro, pues basta a estos efectos, conforme tiene declarado este Centro a partir de la Resolución de 7 de mayo de 1965 (R. 1958, 1957 y N. Dicc. 25895), que existan indicios racionales de que al nacido le corresponde iure sanguinis la nacionalidad española.

CONSIDERANDO: Que esta conclusión, ya reiteradamente sentada por la doctrina de este Centro Directivo, tiene hoy además respaldo constitucional, al estar proclamada la igualdad de los bijos ante la Ley con independencia de su filiación (arts. 14 y 39.2 de la Constitución -R. 1973, 2336-); y con ella se evita que baya supuestos, cuya frecuencia ba aumentado con la emigración, en que queden fuera del Registro -y de la protección como españoles_- personas que «iure sanguinis» tienen esa nacionalidad, pero respecto de los cuales bay de momento dificultades para una determinación oficial de la correspondiente filiación.

Considerando: Que no procede examinar en el caso presente si es o no posible la inscripción de la filiación natural materna -única filiación cuya constancia regis- 
tral ha sido solicitada-, pues no parece concedida la aprobación judicial exigida en el art. 133 del Código Civil para los reconocimientos que de menores se hacen en documento público (fuera de los casos en que sea efectuado en testamento o al inscribirse oportunamente el nacimiento en el Registro Civil español), pues esta aprobación judicial es una de aquellas formas o solemnidades que afectan a la validez o licitud del acto y a la vez exceden de la estricta cuestión de su formalización, y que en este caso son regidas por la ley española por su relación con la capacidad del español reconocido y con la protección de sus intereses personales, por lo cual ha de ser siempre exigida, incluso en el caso de que el acto haya sido otorgado en el extranjero.

ConsIDERANDo: Que, al no poder entrarse a discutir la inscripción de la filiación, hay que cumplir lo especialmente previsto para estos casos por los artículos 213 y 191 del Reglamento del Registro Civil, manteniendo para el no inscrito los apellidos y nombre de padre y madre a efectos identificadores que viniere usando como menciones de identidad.

Considerando: Que, en cuanto al nombre propio, el que viene utilizando el nacido es el francés $\mathrm{O}$., el cual tiene traducción usual a las lenguas españolas y, por tanto, sólo podrá tener acceso al Registro en la versión que elija quien haya de imponer el nombre; por ejemplo, $\mathrm{O}$. en castellano, $\mathrm{O}$. u $\mathrm{O}$. en catalán, todo ello por aplicación de los artículos 192, 213.2. y 212 del Reglamento del Registro Civil.

Considerando: Que, con arreglo a los artículos 98 y 100 de la Ley del Registro Civil y 371 y 376 de su Reglamento, son de oficio todas las costas causadas.

\section{Comentario}

En esta Resolución, a diferencia de su antecedente de 8 de mayo de 1980 (R. 3 del Repertorio de 1980), se aplica directamente el principio de igualdad de los hijos con independencia de su filiación.

Sobre este tema, véase $\mathrm{E}$. Linde, Principio constitucional de igualdad y su aplicación al Derecho civil foral, en «Boletín de Información del Ministerio de Justicia», núm. 1226, de 5 de enero de 1981.

\section{R. 5. Resolución de la Dirección General de los Registros de 23 de julio de 1980 (Repertorio Aranzadi 2.987/1980) : ARTICULOS 16.2, 16.3 Y 53 DE LA CONSTITUCION.}

\section{Matrimonio civil}

Libertad religiosa

Derecho a contraer matrimonio civil por un ordenado in sacris aun en el caso de no haber obtenido dispensa canónica por virtud de la aplicación directa del artículo 16 de la Constitución en relación con el artículo 53 de la misma, que derogan los artículos 42,83.4 y 86 del Código Civil.

\section{Antecedentes:}

Auto de 24 de octubre de 1979 (véase 4011 de este Repertorio 1979), Resolución de la Dirección General de los Registros de 6 de abril 1979 (R. 1 de este Repertorio 1979), Resolución de la Dirección General de los Registros de 19 de octubre de 1979 (R. 2 de este Repertorio 1979), Resolución de la Dirección General de los Registros de 15 de febrero de 1980 (R. 1 de este Repertorio 1980) y Resolución de la Dirección General de los Registros de 13 de marzo de 1980 (R. 2 de este Repertorio de 1980). 
Considerando: Que la cuestión planteada consiste en determinar si el ordenado in sacris puede contraer matrimonio aunque no haya obtenido dispensa canónica.

Considerando: Que entre los derechos y libertades básicas está reconocido el de contraer matrimonio, sin que pueda ser restringido por razones o situaciones de carácter religioso, pues ello constituiría una discriminación prohibida por los Convenios internacionales aplicables en España y, en particular, contraria a la Constitución.

Considerando: Que es indudable que los derechos y libertades reconocidos en el capítulo $2 .^{\circ}$ del Libro I de la Constitución vinculan ya, como establece su artículo 53 (R. 1978, 2836), a todos los poderes públicos y dejan en consecuencia sin valor los preceptos contrarios, cualquiera que sea su rango.

Considerando: Que ha quedado, por tanto, sin vigor el impedimento de carácter religioso contenido en el artículo 83.4 del Código Civil.

Considerando: Que esta conclusión aparece respaldada por la confluencia de otros principios constitucionales, como la no confesionalidad del Estado (art. 16.3) y el que «nadie podrá ser obligado a declarar sobre su ideología, religión o creencias» (art. 16.2).

Considerando: Que si la recta aplicación de este último principio ha obligado a entender (cfr. Instrucción sobre matrimonio civil de 26 de diciembre de 1978) que se ha producido la modificación -en lo opuesto a la Constitución- de los artículos 42 y 86 del Código Civil, al no ser posible inquirir la religión de los contrayentes, forzosamente hay que llegar igualmente a la conclusión de que tampoco puede ser investigada la condición sacerdotal o religiosa de aquéllos ni obligarles a declarar sobre este extremo.

Considerando: Que si el artículo 478 del Código Penal sanciona al juez que autorice a sabiendas la celebración de un matrimonio ilegal, es obvio que esta sanción no puede alcanzar al caso de un matrimonio que, por lo antes razonado, no merece ese calificativo.

CoNSIDERANDo: En fin, que esta doctrina, autorizada por el texto constitucional y por anteriores resoluciones de este Centro, exige por su autoridad - y en bien de la uniformidad y seguridad jurídica- que en el ámbito registral sea acatada por los órganos que están jerárquicamente subordinados al Centro Directivo (cfr. arts. 9 de la Ley del Registro Civil y 41 de su Reglamento) y sin perjuicio, claro es, de la independencia de los mismos órganos en otros ámbitos funcionales.

Constderando: Que, con arreglo a los artículos 98 de la Ley del Registro Civil y 371 de su Reglamento, son gratuitas todas las actuaciones seguidas.

\section{Comentario}

Véase comentario a la Resolución de la Dirección General de los Registros y del Notariado de 15 de febrero de 1980 (núm. 1 del Repertorio de 1980).

Nota.-En el próximo número de esta Revista se incluirán el resto de las Sentencias, Autos y Resoluciones de 1980, así como los Indices correspondientes a 1980. 